THAIS AYA HASSAN INATOMI

\title{
ANÁLISE DA EFICIÊNCIA ENERGÉTICA DO SISTEMA DE CONDICIONAMENTO DE AR COM DISTRIBUIÇÃO PELO PISO EM AMBIENTE DE ESCRITÓRIO, NA CIDADE DE SÃO PAULO, UTILIZANDO O MODELO COMPUTACIONAL ENERGYPLUS.
}

Dissertação apresentada à Escola Politécnica da Universidade de São Paulo para a obtenção do título de Mestre em Engenharia.

SÃO PAULO

2008 
THAIS AYA HASSAN INATOMI

\section{ANÁLISE DA EFICIÊNCIA ENERGÉTICA DO SISTEMA DE CONDICIONAMENTO DE AR COM DISTRIBUIÇÃO PELO PISO EM AMBIENTE DE ESCRITÓRIO, NA CIDADE DE SÃO PAULO, UTILIZANDO O MODELO COMPUTACIONAL} ENERGYPLUS.

Dissertação apresentada à Escola Politécnica da Universidade de São Paulo para a obtenção do título de Mestre em Engenharia

Área de Concentração:

Engenharia de Construção Civil e Urbana

Orientadora:

Prof ${ }^{a}$. Dr ${ }^{a}$. Brenda Chaves Coelho Leite 
Este exemplar foi revisado e alterado em relação à versão original, sob responsabilidade única do autor e com a anuência de seu orientador.

São Paulo, 27 maio de 2008.

Assinatura do autor

Assinatura do orientador

FICHA CATALOGRÁFICA

INATOMI, Thais Aya Hassan

Análise da eficiência energética do sistema de condicionamento de ar com distribuição pelo piso em ambiente de escritorio, na cidade de São Paulo, utilizando o modelo computacional Energyplus / T.A.H. Inatomi. -- ed.rev. -- São Paulo, 2008.

$87 \mathrm{p}$.

Dissertação (Mestrado) - Escola Politécnica da Universidade de São Paulo. Departamento de Engenharia de Construção Civil.

1. Sistemas de refrigeração e ar condicionado 2. Distribuição de ar pelo piso 3. Simulação energética 4. Programa Energyplus I. Universidade de São Paulo. Escola Politécnica. Departamento de Engenharia de Construção Civil II. t. 
Àquele que sempre me guia, Aos meus pais, Nobuoki e Salma. 


\section{AGRADECIMENTOS}

À Profa. Dra. Brenda Chaves Coelho Leite, por sua orientação, incentivo, compreensão e apoio durante o desenvolvimento desta pesquisa.

À Coordenação de Aperfeiçoamento de Pessoal de Nível Superior (CAPES), pela bolsa de estudos concedida.

Aos professores Dr. Cheng Liang Yee, Dr. Arlindo Tribess, Dr. Alberto Hernandez Neto, Dr. Fúlvio Vittorino, da USP. Em especial aos professores Dr. Cheng Liang Yee e Dr. Arlindo Tribess, pela compreensão, apoio e conhecimento repassado.

Ao Dr. Fernando Simon Westphal, pelo apoio e contribuição técnica fundamental na fase final desta pesquisa.

À Fátima Regina Gonçalves e Denise F. S. Alves, da Secretaria de Pós-Graduação, pela atenção proferida.

Aos professores e amigos do Laboratório de Cad (LabCAD), do Departamento de Engenharia de Construção Civil da EPUSP.

À Japan International Corporation Agengy (JICA), e aos professores Dr. Shinsuke Kato, Dr. Ryuzo Ooka e Dr. Takeo Takahashi, da Universidade de Tóquio; Dr. Takashi Akimoto, da Universidade Kanto-Gakuin; Dr. Tomoyuki Chikamoto e Dr. Toshio Yamanaka, da Universidade de Osaka; Dr. Shuichi Hokoi e Dr. Harunori Yoshida, da Universidade de Kyoto; Dr. Akashi Mochida, da Universidade de Tohoku.

Aos amigos Victor F. Barbosa, Fábio K. Motezuki, Danilo de Moura, Chrystianne M. R. Oliveira, Thais C. Oliveira, Lidia M. Maehira, Ana Rosa M. Silva, Ricardo Piergallini, e à familília Hassan de Carvalho, pelo apoio, amizade e incentivo durante todos os momentos.

Ao Rogério Guillen Sampaio, por seu incentivo no início deste processo.

Aos amigos e alunos da Highlight Computação Gráfica e da UNIBAN.

Aos amigos do Centro de Tecnologia em Edificações - CTE, em especial à Rosely Westphal, Saulo Rozendo e Anderson Benite.

Ao arquiteto Tokuji Ito, da Equipe 4 Arquitetos Associados, pelo respeito, inspiração e incentivo durante toda minha carreira.

E finalmente, à minha família e principalmente aos meus pais, pelo esforço e dedicação que me permitiram iniciar esta jornada. 


\section{RESUMO}

Este trabalho tem por finalidade avaliar o desempenho energético do sistema de condicionamento de ar com distribuição pelo piso (Underfloor Air Distribution System UFAD) em ambientes de escritório, considerando diferentes possibilidades de arquitetura do sistema e seus modos de operação com ciclos economizadores. Por meio de simulação computacional, as avaliações foram realizadas para o clima da cidade de São Paulo ao longo de um ano metereológico típico, mantendo as condições de conforto térmico no ambiente. $\mathrm{O}$ programa de simulação selecionado como ferramenta foi o EnergyPlus 2.1.0.023, visto que modelos numéricos nele implementados representam adequadamente o sistema UFAD e os ciclos economizadores. Como referência para o desenvolvimento dos modelos de simulação foi utilizada uma câmara de testes representativa de um ambiente de escritórios. Esta câmara foi desenvolvida por Leite (2003) para avaliação do conforto térmico propiciado pelo sistema UFAD. As curvas de distribuição de temperatura resultantes das simulações foram similares às curvas resultantes das medições executadas por esta autora. As simulações foram realizadas para duas arquiteturas diferentes do circuito de ar (com e sem desvio do ar de retorno) combinados com três diferentes modos de operação relacionados à vazão do ar exterior. A análise dos dados climáticos da cidade de São Paulo demonstra que a tomada de ar exterior pode ser majorada com a utilização de ciclos economizadores, reduzindo o consumo de energia do sistema. Os resultados desta pesquisa indicam uma estreita relação entre arquitetura do sistema, controle dos ciclos economizadores, e dados climáticos, revelando que a combinação entre esses parâmetros pode reduzir em 34,5\% o consumo de energia elétrica do sistema UFAD na cidade de São Paulo.

Palavras-chave: Sistema de Condicionamento de Ar. Distribuição de ar pelo piso. Simulação Energética de Edifícios. Ciclos Economizadores. 


\begin{abstract}
The purpose of this research is to evaluate the energy performance of the Underfloor Air Distribution (UFAD) system at office buildings, considering different air loops design and economizer cycles while keeping thermal comfort for the weather data of São Paulo city, Brazil. Simulations were held using the EnergyPlus software version 2.1.0.023, since its numerical models can well represent UFAD systems and economizer cycles. One chamber representing an office room was used as reference for the simulation models. This chamber was developed by Leite (2003) to evaluate the thermal comfort conditions provided by the UFAD system. The curves of temperature distribution obtained from simulation were similar to those experimentally obtained by Leite (2003). Simulations were performed for two different air loops (with and without return air bypass) combined with three different outside air controls. The São Paulo weather data analysis demonstrates that the outside air flow can be increased with the use of economizer cycles, reducing electric energy consumption of the UFAD system. The results of this research indicate that there is a tight relationship between the system air loop design, economizer cycle control and weather data, which reveals that the combination between these parameters can reduce about $34,5 \%$ the electric energy consumption of UFAD system at São Paulo city.
\end{abstract}

Key-words: Heating, Ventilating Air Conditiong (HVAC) System Underfloor Air Distribution. Energy Building Simulation. Economizer Cycles. 


\section{LISTA DE FIGURAS}

Figura 1 - Consumo Final de Energia Elétrica. Evolução da Participação do Consumo por Setor no Total Brasil 1970 a 2006. 2

Figura 2 - Consumo de energia elétrica por classe ............................................................. 3

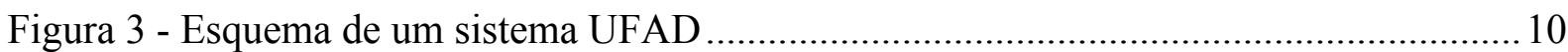

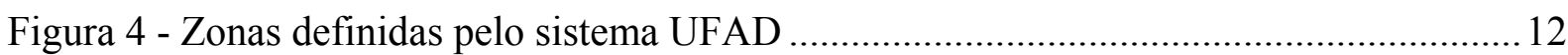

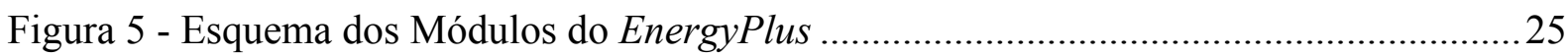

Figura 6 - Subzonas do sistema "UCSD UFAD interior model control"................................22

Figura 7 - Interação dos circuitos do sistema HVAC no EnergyPlus. ..................................... 30

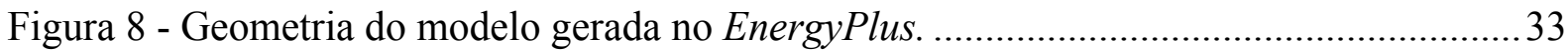

Figura 9 - Perspectiva do Laboratório Representativo de Ambientes de Escritório .................34

Figura 10 - Perspectiva do Laboratório Representativo de Ambientes de Escritório ...............34

Figura 11 - Circuito com desvio de ar de retorno........................................................................ 40

Figura 12 - Corte esquemático do sistema de condicionamento de ar com circuito

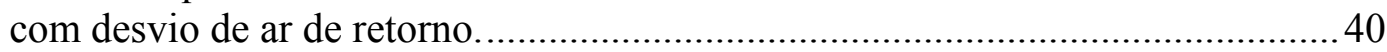

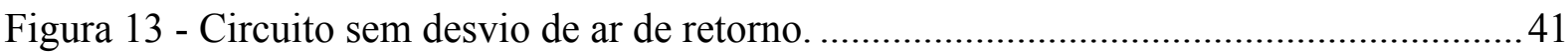

Figura 14 - Corte esquemático do sistema de condicionamento de ar com circuito sem desvio de ar de retorno.

Figura 15 - Carta psicrométrica da cidade de São Paulo. Temperaturas e umidades dos controles dos ciclos economizadores.

Figura 16 - Zonas de conforto para verão e inverno

Figura 17 - Frequência de ocorrência de temperatura de bulbo seco $\leq 13^{\circ} \mathrm{C}$ e umidade relativa $\leq 100$

Figura 18 - Frequência de ocorrência de temperatura de bulbo seco $\leq 17^{\circ} \mathrm{C}$

Figura 19 - Frequência de ocorrência de temperatura de bulbo seco $\leq 17^{\circ} \mathrm{C}$ e umidade relativa $\leq 78$.

Figura 20 - Frequência de ocorrência de temperatura de bulbo seco $\leq 26,5^{\circ} \mathrm{C}$.

Figura 21 - Médias horárias e desvio padrão das temperaturas $\left({ }^{\circ} \mathrm{C}\right)$ e umidades do ar exterior (\%). Meses de Janeiro a Junho.

Figura 22 - Médias horárias e desvio padrão das temperaturas $\left({ }^{\circ} \mathrm{C}\right)$ e umidades do ar exterior (\%).Meses de Julho a Dezembro.

Figura 23 - Médias horárias, máximas e mínimas das temperaturas do ar exterior $\left({ }^{\circ} \mathrm{C}\right)$. Meses de Janeiro a Junho.

Figura 24 - Médias horárias, máximas e mínimas das temperaturas do ar exterior $\left({ }^{\circ} \mathrm{C}\right)$. Meses de Julho a Dezembro.

Figura 25 - Curva representativa da distribuição de temperatura no ambiente, 
resultante de ensaios experimentais realizados por Leite (2003).

Figura 26 - Curvas representativas das distribuições de temperatura no ambiente resultantes dos seis casos simulados (Caso 1 a 6), e curva resultante dos dados medidos em ensaio experimental (Medidos).

Figura 27 - Casos simulados. Gráficos das médias mensais de: temperatura de bulbo seco do ar insuflado, temperatura na zona ocupada, temperatura na zona superior, vazão do ar no ambiente, altura de transição entre as zonas ocupada e superior, e umidade relativa na zona ocupada.

Figura 28 - Conforto térmico no ambiente - PMV.

Figura 29 - Casos simulados. Médias horárias das vazões de tomada do ar exterior $\left(\mathrm{m}^{3} / \mathrm{h}\right)$. Meses de Janeiro a Junho.

Figura 30 - Casos simulados. Médias horárias das vazões de tomada do ar exterior (m3/h). Meses de Julho a Dezembro.

Figura 31 - Média mensal das cargas térmicas de refrigeração dos casos simulados $(\mathrm{Wh} / \mathrm{h})$

Figura 32 - Carga térmica de refrigeração dos casos 1 a $3(\mathrm{Wh} / \mathrm{h})$. Redução da carga térmica de refrigeração dos casos 2 e 3 comparativamente ao caso $1(\%)$.

Figura 33 - Carga térmica de refrigeração dos casos 4 a $6(\mathrm{Wh} / \mathrm{h})$. Redução da carga térmica de refrigeração dos casos 5 e 6 comparativamente ao caso $4(\%)$.

Figura 34 - Médias mensais anuais das cargas térmicas de refrigeração dos casos 1 a $6(\mathrm{Wh} / \mathrm{h})$. Redução da carga térmica de refrigeração dos casos 2 a 6 comparativamente ao caso $1(\%)$.

Figura 35 - Médias mensais do consumo de energia das unidades de resfriamento $(\mathrm{Wh} / \mathrm{h})$

Figura 36 - Médias mensais do consumo de energia das bombas (Wh/h). 73

Figura 37 - Médias mensais do consumo de energia dos ventiladores (Wh/h). 73

Figura 38 - Consumo anual de energia elétrica do sistema de condicionamento de ar dos casos simulados (kWh). Redução do consumo de energia elétrica dos casos 2 a 6 comparativamente ao caso $1(\%)$. 


\section{LISTA DE TABELAS}

Tabela 1- Dados dos materiais de construção. 35

Tabela 2 - Distribuição das cargas internas.

Tabela 3 - Faixas de temperaturas operativas ótimas, pessoas em atividade leve $(\leq 1,2$ met), em ambiente com umidade relativa de $50 \%$ e velocidade média do ar $\leq 0,15 \mathrm{~m} / \mathrm{s}$ (ISO 7730,1994)

Tabela 4 - Escala de Sensação Térmica (ASHRAE, 2004b).

Tabela 5 - Casos simulados.

Tabela 6 - Temperaturas médias em diferentes alturas do ambiente para 20 pontos medidos em ensaio experimental realizado por Leite (2003)

Tabela 7 - Médias das temperaturas obtidas em ensaio experimental (LEITE, 2003), representando as temperaturas em diferentes alturas do ambiente

Tabela 8 - Médias das temperaturas resultantes dos casos simulados, representando as temperaturas em diferentes alturas do ambiente.

Tabela 9 - Média mensal das cargas térmicas de refrigeração dos casos simulados $(\mathrm{Wh} / \mathrm{h})$ 


\section{SUMÁRIO}

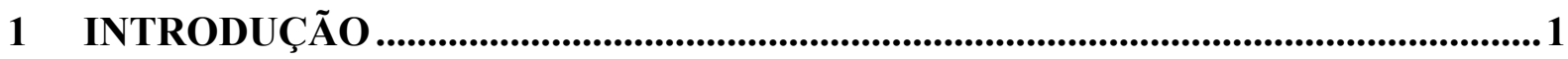

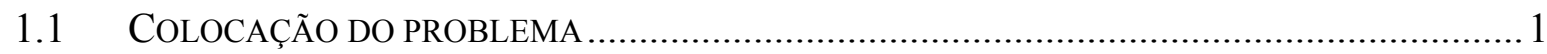

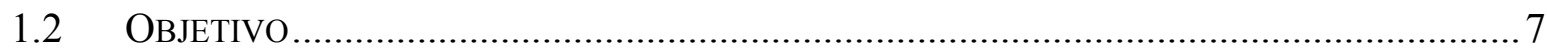

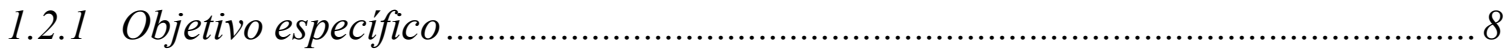

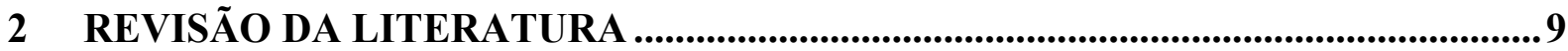

2.1 CARACTERÍSTICAS GERAIS DO SISTEMA UFAD …............................................

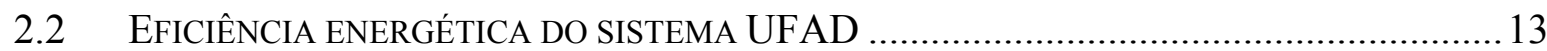

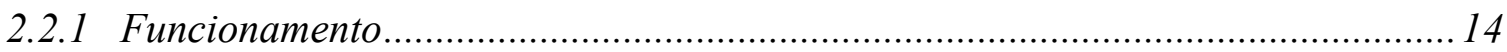

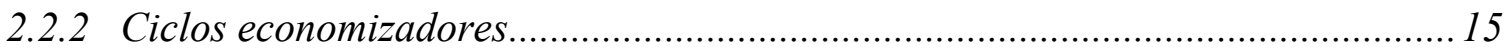

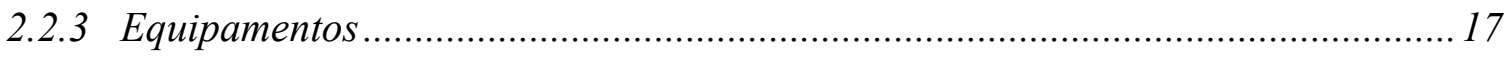

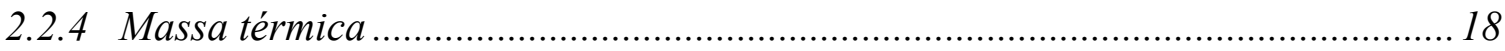

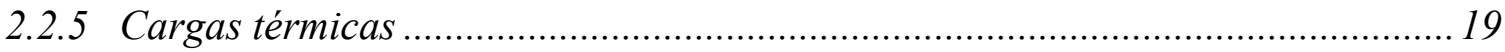

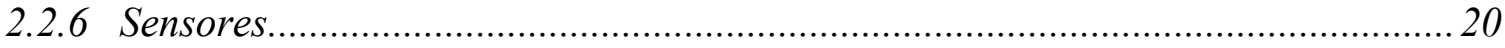

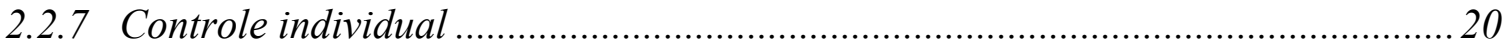

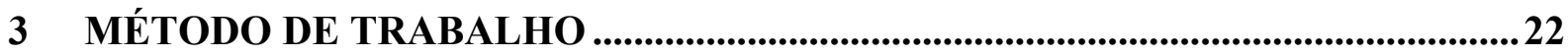

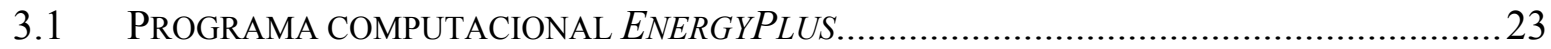

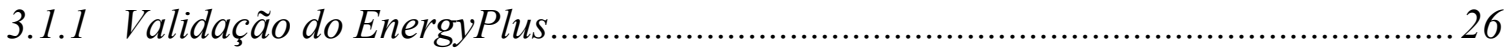

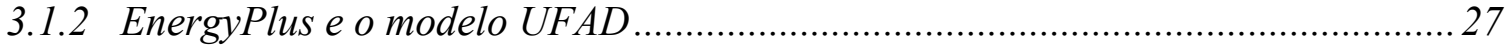

3.1.3 EnergyPlus e o sistema de condicionamento de ar...........................................29

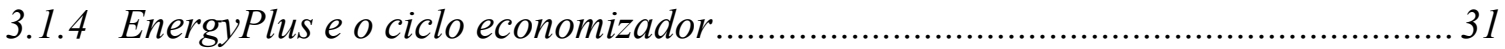

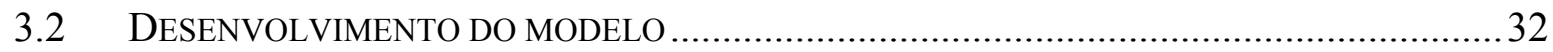

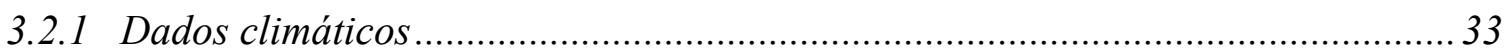

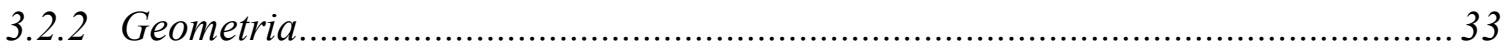

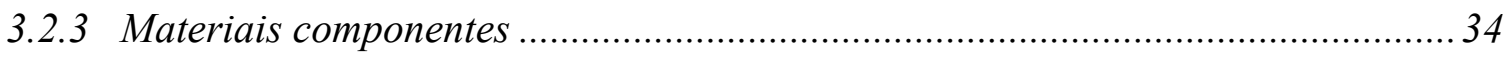

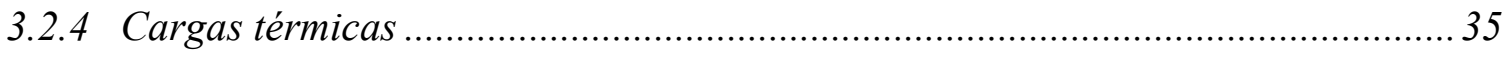


3.2.5 Vestimenta dos usuários......

3.3 DESENVOLVIMENTO DO MODELO DO SISTEMA DE CONDICIONAMENTO DE AR 37

3.3.1 Especificação dos equipamentos.. 37

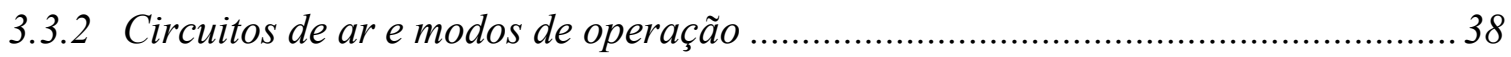

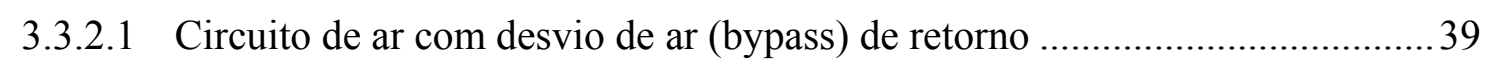

3.3.2.2 Circuito de ar sem duto de desvio de ar de retorno.......................................... 40

3.3.3 Controle da tomada do ar externo ........................................................................ 42

3.3.3.1 Controle das temperaturas limites para tomada do ar exterior .......................43

3.3.3.2 Controle para reutilização do ar de retorno.................................................. 44

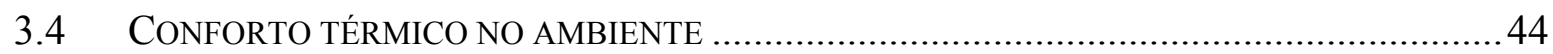

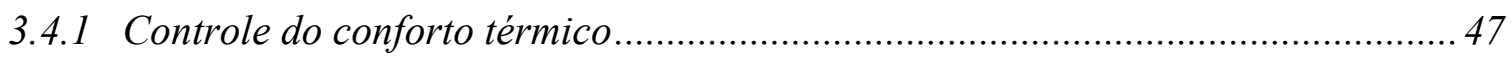

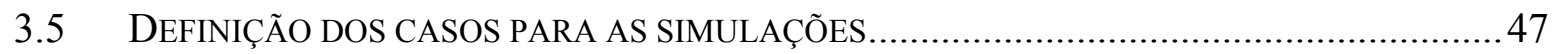

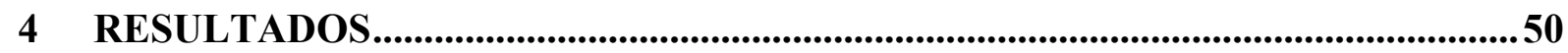

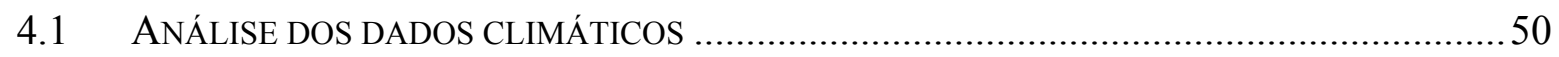

4.2 VERIFICAÇÃO DO DIMENSIONAMENTO DOS EQUIPAMENTOS.......................................57

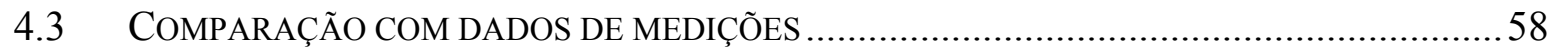

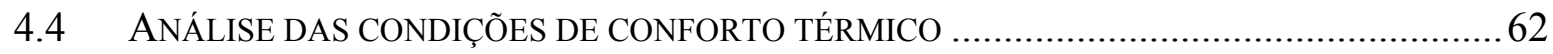

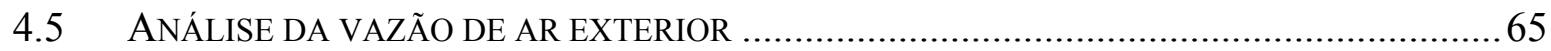

4.6 CARGA TÉRMICA DE REFRIGERAÇÃO E CONSUMO DE ENERGIA ELÉTRICA.....................68

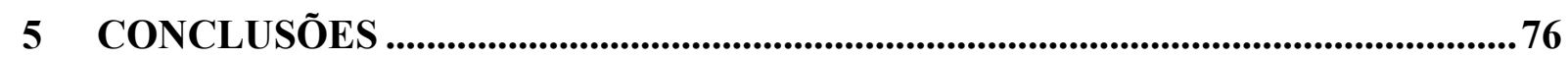

6 REFERÊNCIAS BIBLIOGRÁFICAS .................................................................. 79

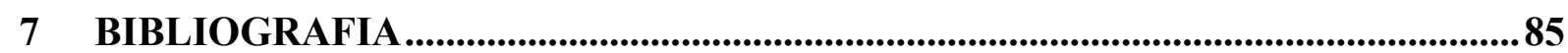




\section{INTRODUÇÃO}

\subsection{COLOCAÇÃO DO PROBLEMA}

A conscientização mundial sobre os impactos ambientais provocados pelo homem iniciou-se na década de 70, e a partir de então, convenções internacionais foram organizadas para discutir possíveis soluções para desacelerar o consumo de recursos naturais e promover a sustentabilidade. Dentre elas pode-se citar: a Conferência das Nações Unidas sobre o Ambiente Humano (Estocolmo, 1972); a Convenção de Viena para Proteção da Camada de Ozônio (Viena, 1985); o Protocolo de Montreal (Montreal, 1987); a Conferência das Nações Unidas sobre Ambiente e Desenvolvimento - ECO’92 (Rio de Janeiro, 1992), Conferência das Nações Unidas (Istambul, 1996), o Protocolo de Kyoto (1997), Convenção-Quadro das Nações Unidas sobre Mudanças do Clima (United Nations Framework Convention on Climate Change, UNFCC, 2007).

Parte do aquecimento global e impactos ambientais irreversíveis podem ser atribuídos à geração de energia elétrica; entretanto, sua utilização é indispensável e extremamente necessária para o desenvolvimento mundial.

No Brasil, a conscientização da necessidade do uso racional de energia elétrica acentuou-se pela crise que afetou o fornecimento e distribuição de energia elétrica em 2001 e 2002. Nesta ocasião, a falta de planejamento e investimentos no setor energético foi agravada pela escassez de chuvas, o que obrigou o país a adotar uma política de racionamento de energia. Em conseqüência desta crise aumentaram as discussões sobre políticas governamentais para suprir as necessidades de expansão da produção de energia, assim como políticas governamentais para redução do consumo da mesma pelo usuário final.

A quantificação não só dos custos, mas também dos impactos, principalmente ambientais, provocados pela implantação de usinas para geração de energia elétrica, indica que medidas emergenciais devem ser tomadas para o controle do consumo energético, e que a implantação de novas usinas deve ser minuciosamente planejada e efetuada somente se necessário, isto é, no caso em que, mesmo com medidas eficientes de controle de demanda, esta ainda se projete maior que a oferta.

Neste sentido, a busca do setor energético pela redução do consumo de energia nas edificações deveria ser desenvolvida por meio do Planejamento de Recursos Integrado (PIR), 
mais especificamente do Gerenciamento da Demanda de Energia. O PIR busca o desenvolvimento de soluções integradas de recursos renováveis que possibilitem diminuição de custos completos e mitigação de impactos ambientais e sociais. No Gerenciamento de Demanda se desenvolvem medidas e legislações que promovam o uso racional de energia, tais como programas de tarifação, horário de verão, incentivo à fabricação e utilização de equipamentos de baixo consumo, e incentivo ao uso de energia renovável.

Dados do Balanço Energético Nacional de 2007 (figura 1) demonstram o crescente consumo de energia elétrica nacional ao longo do tempo, e apontam que $44,6 \%$ do consumo total de energia elétrica do país é distribuído entre os setores residencial (22\%), comercial e público (22,6\%) (BRASIL, 2007).

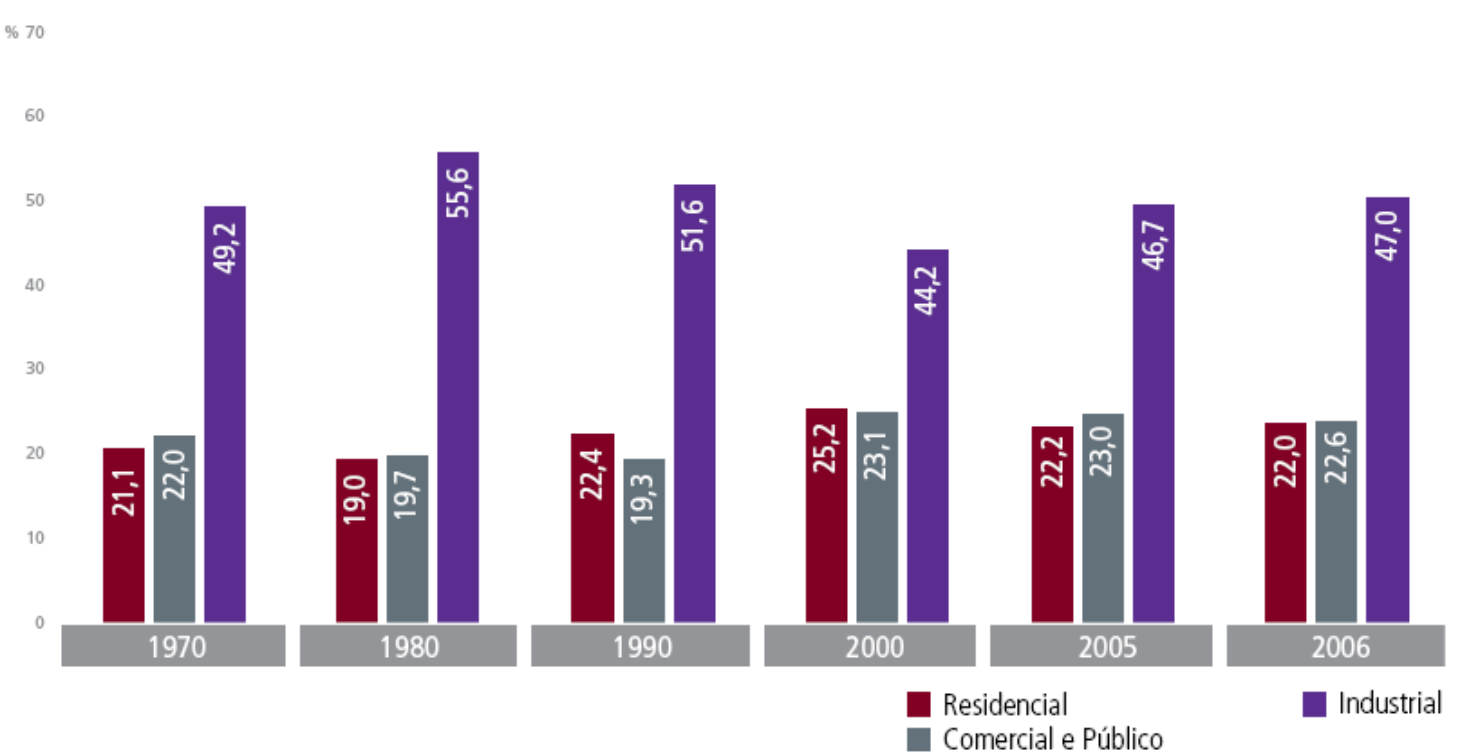

Figura 1 - Consumo Final de Energia Elétrica. Evolução da Participação do Consumo por Setor no Total Brasil 1970 a 2006. Fonte: Brasil (2007).

A cidade de São Paulo é um dos melhores exemplos brasileiros de conglomerados de edifícios do setor comercial e público. É nesta cidade que se localiza a maior quantidade de edifícios comerciais do país, sendo que o setor comercial consumia aproximadamente $28 \%$ da energia elétrica do município no período de 1997 e 1998 (figura 2). Segundo dados divulgados pela Prefeitura da cidade de São Paulo,

"entre 1991 e 2005 , destacou-se o aumento de mais de $100 \%$ no consumo energético para o uso comércio e serviços e, em contrapartida, houve uma diminuição de 50\% do consumo industrial. Em 2006, manteve-se a mesma 
tendência: aumento do consumo no setor de comércio/serviços e diminuição na atividade industrial" (SÃO PAULO, 2008).

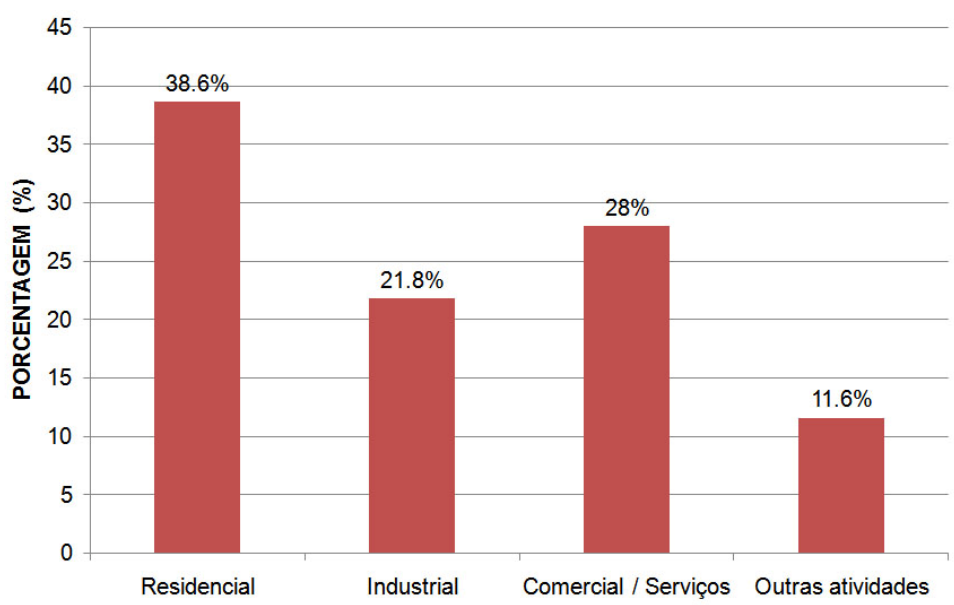

Figura 2 - Consumo de energia elétrica por classe referente ao ano de 1998. Fonte: Eletricidade de São Paulo/Eletropaulo (SÃO PAULO, 2008a).

Considerando que o consumo do setor comercial está diretamente relacionado à própria edificação onde atua (BULLA, 1995), pode-se afirmar que o consumo de energia do setor comercial está ligado às características arquitetônicas e de padrões de uso da edificação.

Segundo Wines (2000) apud Lamberts et al. (2008),

"a construção e o uso dos edifícios são um dos maiores consumidores dos recursos naturais no ambiente, consumindo $16,6 \%$ do fornecimento mundial de água pura, $25 \%$ de sua colheita de madeira e $40 \%$ de seus combustíveis fósseis e materiais manufaturados."

"Esta indústria responde também pelo processo de contaminação atmosférica, sendo responsável por uma grande parcela das emissões de $\mathrm{C}_{2}$, principal gás responsável pelo efeito estufa. No Brasil, a indústria cimenteira contribui atualmente com $6 \%$ a $8 \%$ do $\mathrm{CO}_{2}$ emitido (JOHN, 2000 apud LAMBERTS et al., 2008).”

Pesquisas neste sentido reavaliam o consumo de energia desde a concepção dos materiais de construção ao desempenho do edifício e integração com o usuário final, e indicam que as edificações (residenciais, comerciais, institucionais) e seus materiais de construção consomem mais da metade da energia global por ano (MAZRIA, 2004).

A eficiência energética das edificações é, portanto, primordial para um desenvolvimento sustentável, o que conduz engenheiros e arquitetos a repensar as técnicas de 
projeto e tecnologias, avaliando possibilidades de interação de métodos ativos e passivos que diminuam o consumo energético e atendam às necessidades dos usuários, como, por exemplo, naquilo que se aplica ao conforto térmico, acústico, lumínico e psicológico.

No quesito desempenho do edifício, podem-se definir como edifícios energeticamente eficientes os que, em se mantendo o conforto ambiental e a qualidade do ar, consomem menos energia elétrica, mitigando impactos ambientais e sócio-econômicos. Para avaliar tal desempenho, leis e incentivos, no âmbito nacional e internacional, estão sendo desenvolvidas, tendo como referência: a ASHRAE Standard 90.1-2004 - Energy Standard for Buildings Except Low-Rise Residencial Buildings (ASHRAE, 2004d), que dispõe sobre as necessidades mínimas de eficiência energética para projeto e construção de edifícios e seus sistemas; a ASHRAE Standard 55-2004 - Thermal Comfort Conditions for Human Occupancy (ASHRAE, 2004b), que dispõe sobre as combinações do ambiente do espaço interno e fatores pessoais que proporcionam condições ambientais térmicas aceitáveis para 80\% ou mais ocupantes do espaço; e ASHRAE Standard 62.1-2004 - Ventilation for Acceptable Indoor Air Quality (ASHRAE, 2004c), que dispõe sobre as taxas mínimas de ventilação e qualidade do ar interno aceitáveis pelos ocupantes e que minimizam potenciais efeitos nocivos à saúde dos mesmos.

No contexto internacional, vários países estão aplicando ou produzindo leis, incentivos ou métodos de classificação que promovam a construção de edifícios de baixo impacto ambiental, e conseqüentemente, com consumo de energia reduzido. Podem ser citados: LEED (Leadership in Energy and Environmental Design), BREEAM e ECOHOMES, CASBEE (Comprehensive Assessment System for Building Environmental Efficiency), HQE (Haute Qualité Environnementale dês Batiments), e o GREEN STAR.

No contexto nacional, a Lei $\mathrm{n}^{\circ} 10.295$, de 17 de outubro de 2001, dispõe sobre a Política Nacional de Conservação e Uso Racional de Energia, e institui os níveis máximos de consumo de energia, ou mínimos de eficiência energética de máquinas e aparelhos consumidores de energia fabricados ou comercializados no país, bem como as edificações construídas. Os principais órgãos envolvidos no desenvolvimento e cumprimento de tal meta são: a Agência Nacional de Energia Elétrica (ANEEL), a Agência Nacional do Petróleo (ANP), o Instituto Nacional de Metrologia, Normalização e Qualidade Industrial (INMETRO), as Secretarias Executivas do Programa Nacional de Conservação de Energia Elétrica (PROCEL) e do Programa Nacional de Racionalização do Uso de Derivados de Petróleo e do Gás Natural (CONPET). 
Baseada em tal lei foi desenvolvida, como parte do programa PROCEL Edifica, a "Regulamentação de etiquetagem voluntária de nível de eficiência energética de edifícios comerciais e públicos". Aprovada em setembro de 2006 pelo Comitê Gestor de Indicadores e Níveis de Eficiência Energética (CGIEE) e pelo Ministério de Minas e Energia (MME), ela é atualmente de caráter voluntário e avalia as edificações a partir do desempenho dos sistemas de iluminação, da eficiência dos sistemas de condicionamento de ar, e desempenho da envoltória (LAMBERTS et al., 2008).

A busca pela redução do consumo de energia altera definitivamente a concepção das edificações e reflete diretamente em seus projetos e retrofits, e em novas concepções de sistemas de condicionamento de ar, como exemplifica Atikol (2004).

O consumo de energia elétrica de edifícios de escritórios é devido principalmente aos sistemas de iluminação, equipamentos de escritório e sistemas de condicionamento de ar. Eles são responsáveis, respectivamente, por $24 \%, 15 \%$ e $48 \%$ do consumo do edifício (LAMBERTS; DUTRA; PEREIRA, 1997). Nota-se que grande parte do consumo de energia dos edifícios de escritórios é conseqüência do sistema de condicionamento de ar, ou seja, para promover conforto térmico (LEITE, 2003).

Os sistemas de aquecimento, ventilação e condicionamento de ar (Heating, Ventilation and Air Conditioning - HVAC) são, portanto, responsáveis por grande parte do consumo de energia das edificações, sendo que muitos são os fatores que influenciam a operação e a eficiência energética de tais sistemas. Dentre eles pode-se citar: o próprio sistema, com suas características intrínsecas e seus modos de operação, clima local, arquitetura da edificação e seus materiais de construção, assim como parâmetros internos tais como densidade de ocupação e tipo de trabalho desenvolvido no ambiente condicionado (INATOMI; ABE; LEITE, 2006).

Neste contexto, pesquisas tais como de Loudermilk (1999, apud Lin e Linden, 2005), Leite (2003), Bauman (2003), Chang, Kato e Chikamoto (2004), Architectural Energy Corporation (2004), McCarry (1995), Matsunawa, Iizuka e Tanabe (1995), Heinemeier, Schiller e Benton (1990), Wang, Arens e Webster (2002) e Bauman e Webster (2001), Webster, Ring e Bauman (2000), indicam que o sistema de climatização com distribuição de ar pelo piso (Underfloor Air Distribution System - UFAD), além de proporcionar conforto térmico ao usuário, é promissor na redução do consumo de energia, podendo sua eficiência ser majorada em função da possibilidade de utilização de ciclos economizadores, dependendo das condições climáticas locais. 
Até o fim da década de 1990 o uso do sistema de climatização com distribuição de ar pelo piso era limitado a centros de processamento de dados (CPD) principalmente nos Estados Unidos, África do Sul, Japão, Alemanha, Suíça e Itália. Desde sua introdução, este sistema despertou o interesse de pesquisadores, principalmente nos Estados Unidos, Europa, Japão e, mais recentemente, no Brasil. Tais pesquisas estudam as situações de conforto térmico promovidas por tal sistema em ambientes de escritórios, que dependem das condições térmicas resultantes no ambiente e sua aceitação por parte dos usuários (LEITE, 2003).

O sistema UFAD fornece ar resfriado por meio de difusores instalados no piso, proveniente de um plenum, que é o espaço livre de cerca de $30 \mathrm{~cm}$ entre a laje e o piso elevado.

\begin{abstract}
"Tem como principais características as seguintes: promove a troca de calor com o ambiente mais rapidamente, pode climatizar apenas o volume de ar do espaço efetivamente ocupado, opera com temperaturas do ar mais altas do que as adotadas nos sistemas convencionais com insuflação pelo teto e permite mudanças de localização dos pontos de captação de ar no piso pela ausência de dutos, promovendo flexibilidade" (LEITE, 2003).
\end{abstract}

A potencial eficiência energética do sistema de condicionamento de ar com distribuição pelo piso atualmente estimula o desenvolvimento de diversas pesquisas científicas. Tais pesquisas abordam o consumo de energia do sistema UFAD e suas relações com temperaturas e vazões de ar de insuflação e retorno, cargas térmicas, estratificação da temperatura do ar, pressões no plenum, equipamentos (ventiladores, serpentinas de esfriamento, unidades de resfriamento), influências climáticas, estratégias de controle de vazão e temperatura do ar, questões relacionadas ao projeto e possibilidades de combinações com outros sistemas.

No Brasil, pesquisas desenvolvidas na Escola Politécnica da Universidade de São Paulo tratam de assuntos relativos ao sistema UFAD. A exemplo disto, Leite (2003) verificou que o sistema UFAD promove condições de conforto térmico adequadas e indicou a potencialidade de redução de consumo de energia pela possibilidade de não se usar a refrigeração para o condicionamento do ar insuflado no ambiente (free-cooling) durante períodos específicos do ano, tendo em vista as condições climáticas favoráveis de algumas regiões do Brasil. Pustelnik (2005) efetuou a avaliação numérica de ambientes com insuflação de ar pelo piso utilizando-se de análise computacional de dinâmica dos fluidos (Computational Fluids Dynamics -CFD). Pustelnik (2005) verificou o modelo de turbulência 
mais adequado a ser utilizado na avaliação de sistemas UFAD pelo programa Fluent, além das dificuldades de simulação em função da falta de implementação de dados referentes a difusores do sistema UFAD no programa. Abe (2007) apresentou uma estratégia para a determinação dos parâmetros de operação do sistema UFAD, baseando-se no estabelecimento de inter-relações dos principais parâmetros que definem o escoamento do ar em ambientes com o sistema de distribuição de ar pelo piso: a vazão de ar insuflado, a temperatura do ar insuflado e a diferença de pressão entre o plenum pressurizado e o interior do ambiente.

Dentre as lacunas existentes sobre a análise de desempenho do sistema UFAD podem ser citadas: ausência de normas apropriadas para projeto e avaliação do sistema; necessidade de pesquisas que analisem isoladamente as condições de conforto térmico local proporcionadas pelo sistema (diferença vertical da temperatura do ar entre o nível da cabeça de uma pessoa sentada e o nível dos pés, insatisfação com correntes de ar, temperatura superficial do piso) (INATOMI et al., 2007); estudos dos equipamentos e componentes e suas possibilidades de funcionamento tendo em vista as características do sistema; e necessidade de estudos de caso.

A carência de informações detalhadas que garantam a eficiência do sistema UFAD faz com que a utilização de sistemas de condicionamento de ar com insuflação através de rede de dutos e distribuição pelo no teto seja mais frequente em edifícios comerciais. Entretanto, nota-se uma mudança de comportamento do mercado imobiliário corporativo brasileiro que, visando construções de baixo impacto ambiental, redução no consumo de energia durante a operação do edifício, flexibilidade de adequação de layouts e conforto dos usuários, começam a considerar o uso do sistema UFAD como uma opção.

Neste sentido, propõe-se o desenvolvimento de uma pesquisa para avaliar a eficiência de um sistema dessa natureza, cujos resultados sirvam para suprir a carência de informações referida acima.

\subsection{OBJETIVO}

Esta pesquisa objetiva avaliar o desempenho energético do sistema de climatização com distribuição de ar pelo piso (Underfloor Air Distribution System - UFAD) considerando diferentes possibilidades de arquitetura do sistema e seus modos de operação com ciclos economizadores, mantendo as condições de conforto térmico humano em ambientes de 
escritórios, na cidade de São Paulo, com o auxílio de simulações computacionais executadas no programa EnergyPlus.

\subsubsection{Objetivo específico}

O objetivo específico é identificar, para o clima da cidade de São Paulo, qual é a influência da vazão de tomada de ar externo no consumo de energia do sistema de condicionamento de ar com distribuição pelo piso (Underfloor Air Distribution System UFAD). 


\section{REVISÃO DA LITERATURA}

O estado da arte das pesquisas sobre a eficiência energética do sistema UFAD é apresentado a seguir. Primeiramente, são descritas as características gerais do sistema, identificando as suas influências no consumo de energia. Posteriormente, são arrolados os principais tópicos que se referem aos aspectos abordados nesta pesquisa, focando no consumo de energia elétrica do sistema UFAD.

\subsection{CARACTERÍSTICAS GERAIS DO SISTEMA UFAD}

Pesquisas como de Leite (2003) e Bauman e Webster (2001), afirmam que o sistema UFAD promove:

a) Melhoria das condições de conforto térmico, possibilitando o controle individualizado de vazão do ar;

b) Melhoria na qualidade do ar em relação a sistemas com insuflação pelo teto, uma vez que a idade do $\operatorname{ar}^{1}$ respirado pelos usuários é menor;

c) Flexibilidade para mudanças de layout sem prejuízo do conforto térmico, uma vez que existe a possibilidade de deslocamento dos difusores e controle individual de vazão de ar resfriado;

d) Redução da altura de novas edificações pois não necessita de espaço para passagem de dutos de ar no forro, o que pode reduzir o custo de construção da edificação e aumentar a área construída onde gabaritos de altura são impostos;

e) Possibilidade de redução no consumo de energia devido às temperaturas mais elevadas de insuflação do ar, e menor volume de ar a ser resfriado;

f) Melhoria da produtividade e saúde dos usuários de ambientes por ele condicionados.

Os sistemas de condicionamento de ar com distribuição pelo piso (Underfloor Air Distribution - UFAD) são compostos basicamente por uma câmara de ar frio (plenum), formada pelo vão entre um piso elevado e a laje de concreto do pavimento, suprida por uma

\footnotetext{
${ }^{1}$ Idade do ar é definida como "o espaço de tempo em que determinada quantidade de ar exterior mantém-se em um edifício, zona ou espaço” (ASHRAE, 2005).
} 
unidade primária de tratamento do ar (geralmente serpentina de resfriamento e ventilador - fan coil) e unidades terminais (difusores) que distribuem o ar nos ambientes (LEITE, 2003).

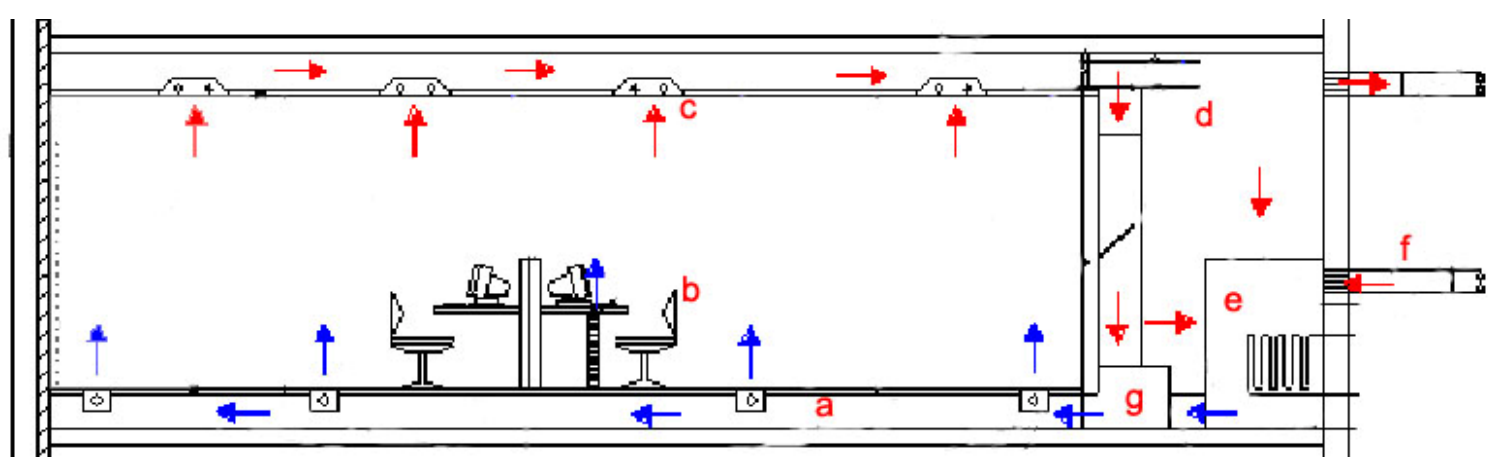

Figura 3 - Esquema de um sistema UFAD (LEITE,2003)

O ciclo do ar no sistema UFAD é ilustrado na figura 3 e pode ser resumido como segue:

a) $\mathrm{O}$ ar resfriado, em geral por uma unidade de tratamento de ar, é insuflado no plenum inferior - compreendido entre o piso elevado e a laje de piso - e distribuído no ambiente por meio de difusores instalados nas placas piso elevado ou nas estações de trabalho;

b) Esse ar entra em contato com os dissipadores de calor, tais como pessoas e computadores e, devido às trocas térmicas, é aquecido, formando as chamadas plumas térmicas;

c) Pelo efeito da convecção natural, e, especificamente neste sistema, com o auxílio de sistema de exaustão mecânica, o ar aquecido sobe e entra no plenum (ou duto) superior de retorno, compreendido entre o forro e a laje do teto;

d) Parte do ar de retorno é expurgado e parte reaproveitado;

e) $\mathrm{O}$ ar de retorno mantindo no sistema pode ser reaproveitado de duas maneiras:

i. seu volume total é resfriado pelo sistema até a temperatura ideal para ser insuflado novamente no plenum inferior;

ii. apenas parte deste volume é resfriado, para então ser misturado com o volume do ar de retorno não resfriado e assim atingir a temperatura ideal de insuflação;

f) Ao ar de retorno a ser resfriado é adicionado determinado volume de ar exterior, volume este que deve ser no mínimo suficiente para garantir a taxa de renovação do ar de $27 \mathrm{~m}^{3} / \mathrm{h}$ por pessoa proposta pela ANVISA (BRASIL, 2003). 
g) Depois de condicionado, o ar é novamente insuflado no plenum inferior, reiniciando o ciclo do ar.

A diferença de pressão do ar do plenum inferior em relação ao ambiente caracteriza três maneiras de funcionamento do sistema UFAD:

a) Sistema com pressão negativa (pressão instantânea no plenum inferior à do ambiente) ou "pressão zero" (quando não há solicitação de vazões de ar no ambiente, não há diferencial de pressão). Neste sistema são necessários difusores ativos para a insuflação do ar, ou seja, os difusores possuem ventiladores individuais motorizados responsáveis por insuflar o ar frio do plenum no ambiente;

b) Sistema com pressão positiva (pressão no plenum superior à do ambiente). Neste sistema a diferença de pressão entre o plenum inferior e o ambiente faz com que o ar frio do plenum seja introduzido no ambiente por meio de difusores passivos (grelhas sem dispositivos motorizados);

c) Sistema dutado. Neste sistema, dutos semelhantes aos do sistema de distribuição de ar pelo teto são instalados sob o piso e conectados a difusores passivos. Não é muito usual devido às limitações de altura do piso elevado, tanto no que se refere às dimensões dos dutos quanto às dificuldades de instalação juntamente com cabeamentos (LEITE, 2003).

A distribuição do ar também pode ser realizada por meio de difusores localizados diretamente na área de trabalho do usuário, caracterizando o condicionamento térmico individualizado (Task/Ambient Conditioning System).

A insuflação do ar no sistema UFAD é feita a baixas velocidades, de maneira que a velocidade do ar na área de trabalho não exceda $0,25 \mathrm{~m} / \mathrm{s}$ (NBR 6401/1980), e a temperaturas de bulbo seco que variem entre $16^{\circ} \mathrm{C}$ e $20^{\circ} \mathrm{C}$ (BAUMAN, 2003; LEITE, 2003), com umidade relativa entre $60 \%$ e $80 \%$, quando os difusores são instalados no piso, ou entre $20,5^{\circ} \mathrm{C}$ e $23,5^{\circ} \mathrm{C}$, com umidade relativa entre $50 \%$ e $70 \%$, quando os difusores são instalados nas estações de trabalho (LEITE,2003).

A temperatura do ar insuflado é superior àquela utilizada pelo sistema de condicionamento pelo teto $\left(13^{\circ} \mathrm{C}\right)$ e a regulagem da vazão de ar pode ser feita manualmente pelos usuários, diretamente nos difusores. A turbulência gerada pela insuflação do ar é suficiente apenas para efetuar a mistura deste na zona de ocupação (ou zona inferior), caracterizando um regime de fluxo de ar muito semelhante à ventilação por deslocamento (displacement ventilation). A vazão do ar insuflado pelo piso é controlada de maneira a garantir a mistura e a qualidade do ar na altura da respiração, e a partir desta, inicia-se a 
estratificação do ar como resultado do fenômeno físico da convecção, pelo qual o ar quente tende a subir naturalmente.

Um corte esquemático de um ambiente de escritórios com sistema UFAD instalado demonstra que quatro zonas são geradas em função do fluxo de ar característico do sistema (Figura 4):

a) Zona inferior (zona de ocupação) - é adjacente ao piso e sua altura varia de acordo com a vazão de ar insuflado. Nesta zona o ar é relativamente bem misturado devido à velocidade de insuflação do ar pelos difusores.

b) Zona média (zona de estratificação) - é a área de transição entre as zonas superior e inferior do ambiente, onde a movimentação do ar é inteiramente por convecção em função das plumas térmicas ascendentes. É a zona de estratificação do ar, e sua existência e altura dependem da vazão do ar insuflado no ambiente através dos difusores.

c) Zona superior - é composta por ar aquecido e contaminado pelas plumas térmicas. Nesta zona, apesar das baixas velocidades médias, o ar é relativamente bem misturado, resultado do momento gerado pela penetração das plumas térmicas no seu limite inferior.

d) Zona limpa (clear zone) - Devido às correntes de ar excessivas e temperaturas baixas resultantes da vazão nos difusores, a região compreendida no raio de $80 \mathrm{~cm}$ de distância do mesmo não são recomendadas para ocupação.

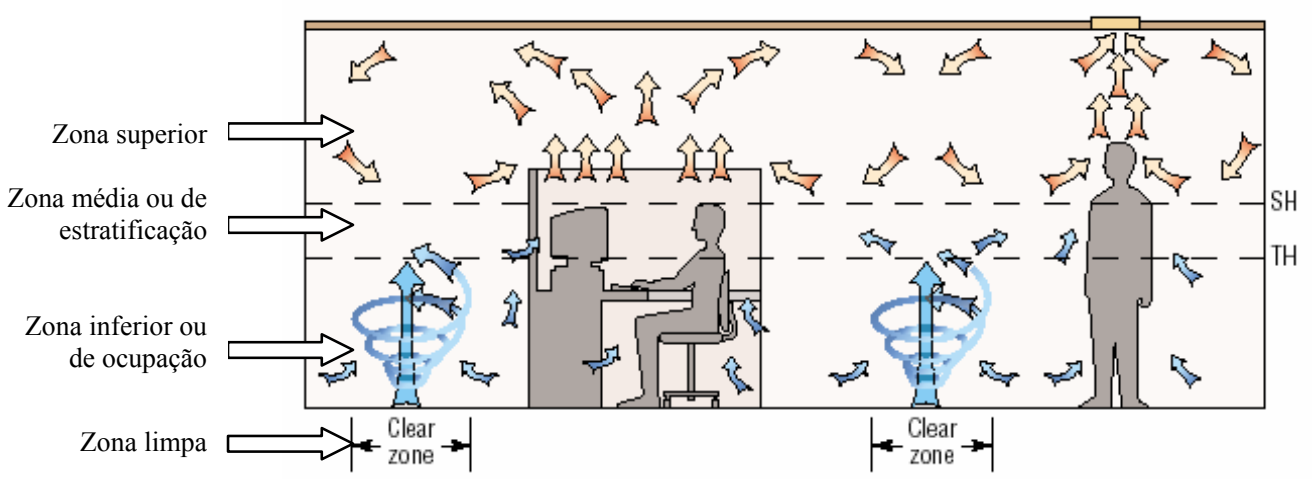

Figura 4 - Zonas definidas pelo sistema UFAD. Fonte: Bauman (2003).

Em planta, o ambiente é dividido por zonas de acordo com a concentração e tipos de cargas térmicas:

a) Zonas perimetrais (próximas às envoltórias); 
b) Zonas interiores com alta densidade ocupacional (estações de trabalho);

c) Zonas interiores com baixas cargas (corredores e áreas de uso comum).

Segundo Sodec e Craig (1990) apud Leite (2003), em edifícios de escritórios a carga térmica estimada nos espaços é: nas zonas perimetrais, de 50 a $70 \mathrm{~W} / \mathrm{m}^{2}$; e nas zonas internas, de 30 a $50 \mathrm{~W} / \mathrm{m}^{2}$ de área de piso. Para remover esta carga térmica é necessária uma vazão de ar de suprimento da ordem de 5 a $7 \mathrm{~L} / \mathrm{s} / \mathrm{m}^{2}$ nas zonas perimetrais e 3 a $5 \mathrm{~L} / \mathrm{s} / \mathrm{m}^{2}$ nas zonas internas.

Pesquisa realizada por Webster et al. (2002), indica que a vazão de $3 \mathrm{~L} / \mathrm{s} / \mathrm{m}^{2}$ é adequada para que o sistema UFAD tenha seu consumo de energia reduzido, mantendo as condições de conforto no ambiente, e evitando a estratificação excessiva do ar.

Segundo o Center for the Building Environment (2008), enquanto o sistema de distribuição pelo piso consegue manter as cargas térmicas estáveis nas zonas internas, nas zonas perimetrais esta estabilidade é mais difícil de ser alcançada em virtude das rápidas variações de carga térmica resultantes da radiação solar na envoltória. Obviamente isto depende do clima local e da arquitetura da edificação, no que se refere a proteções solares, especificação de vidros e materiais de construção. Entretanto, nota-se que as zonas perimetrais requerem um sistema separado, ou ao menos soluções híbridas em que ventiladores e/ou equipamentos adicionais sejam utilizados para remover as cargas térmicas dessas zonas.

Segundo Leite (2003), nas zonas perimetrais geralmente são instaladas caixas com reguladores de vazão de ar e ventilador com difusor acoplado a um duto flexível, controlados por termostatos, para responder pelas cargas térmicas originadas principalmente pela radiação solar.

\subsection{EFICIÊNCIA ENERGÉTICA DO SISTEMA UFAD}

As características que potencializam a eficiência energética do sistema UFAD serão arroladas a seguir no intuito de identificar os caminhos que devem ser percorridos para uma análise quantitativa de seu consumo energético e avaliar as melhores formas de operação do sistema.

Apesar de várias serem as pesquisas que discorrem sobre a redução do consumo de energia do sistema UFAD em comparação ao sistema convencional com insuflação pelo teto, 
poucas são as que indicam quantitativamente essa redução, restringindo-se à descrição de fatores que podem contribuir com a mesma.

\subsubsection{Funcionamento}

Segundo Loudermilk (1999), apud Lin e Linden (2005), Leite (2003), Bauman (2003), a eficiência energética do sistema UFAD está diretamente relacionada ao que segue:

a) o ar é resfriado para condicionar apenas a área de ocupação. Os ganhos de calor por convecção que acontecem acima da zona de ocupação são isolados do cálculo da vazão de ar requerida para a manutenção do conforto térmico dos usuários;

b) as temperaturas do ar de insuflação $\left(\right.$ de $16^{\circ} \mathrm{C}$ a $20^{\circ} \mathrm{C}$ ) são mais altas do que as adotadas pelos sistemas com distribuição de ar pelo teto $\left(13^{\circ}\right)$. Logo, as solicitações dos equipamentos são minimizadas visto que as temperaturas de insuflação do ar são mais próximas das temperaturas para conforto (em torno de $24^{\circ} \mathrm{C}$ ), e a possibilidade de utilização de ciclos economizadores é majorada quando da ocorrência de condições climáticas favoráveis.

Segundo Lin e Linden (2005), o tipo de fluxo que ocorre na zona superior de ambientes com sistema UFAD serve para transportar o calor eficientemente para aberturas de exaustão localizadas na base do teto, resultando em melhor eficiência de resfriamento.

Tal característica do sistema UFAD tem instigado pesquisas tais como de Chang, Kato e Chikamoto (2004), que estudaram, por meio de análises computacionais de dinâmica dos fluidos (Computational Fluid Dynamics - CFD), o sistema híbrido de condicionamento de ar com distribuição pelo piso e a ventilação natural, com resultados favoráveis ao uso de tal sistema em função das condições externas e indicando seu potencial de conservação de energia.

A possibilidade de utilização do sistema de condicionamento de ar com distribuição pelo piso de forma híbrida com a ventilação natural também foi alvo da pesquisa de Song e Kato (2004), que avaliaram o sistema híbrido de condicionamento de ar por painéis radiantes e ventilação natural cruzada, e compararam-no com o sistema híbrido de condicionamento de ar com distribuição pelo piso e ventilação natural cruzada. Neste caso, os resultados indicam que no quesito eficiência energética a utilização de painéis radiantes com a ventilação cruzada é mais favorável. 


\subsubsection{Ciclos economizadores}

Chang, Kato e Chikamoto (2004), Leite (2003), Architectural Energy Corporation (2004), McCarry (1995), Matsunawa, Iizuka e Tanabe (1995), e Heinemeier, Schiller e Benton (1990), indicam que em regiões de clima ameno, ou seja, sem variações abruptas de temperatura, o sistema UFAD pode atuar com ciclos economizadores, insuflando o ar exterior sem que este seja resfriado (free-cooling), por várias horas durante o ano, proporcionando economia de energia. Isto significa que, de acordo com as condições climáticas (temperatura e umidade do ar exterior), a vazão de tomada do ar exterior pode ser aumentada e, caso o ar exterior esteja em condições similiares às estabelecidas para o ar de insuflação, este ar pode ser insuflado diretamente no ambiente, dispensando o uso das unidades e serpentinas de resfriamento.

A norma ASHRAE Standard 62.1 (ASHRAE, 2004c) propõe, para diferentes tipos e usos de edificação, cálculos para renovações mínimas de ar, concentração de gases e particulados nos ambientes internos, no intuito de manter a qualidade do ar interno.

No Brasil, é a Resolução RE ANVISA Nº (BRASIL, 2003) que estabelece padrões mínimos de qualidade do ar interno, e propõe que a vazão de ar exterior deve ser suficiente para garantir a taxa de renovação do ar de $27 \mathrm{~m} 3 / \mathrm{h}$ por pessoa. Acima desta taxa, pode-se dizer que a eficiência de ventilação está sendo majorada.

A tomada de ar exterior é fundamental nos sistemas de condicionamento de ar para manter a qualidade do ar interno, e pode ser controlada das seguintes maneiras: mantendo-se uma vazão mínima fixa calculada em projeto; por entalpia do ar exterior; por temperaturas de bulbo seco do ar exterior; por controle de demanda no ambiente.

Os ciclos economizadores de ar podem ser entendidos como operações de controle de tomada do ar exterior que proporcionam redução de consumo de energia e majoração da eficiência de ventilação dos sistemas de condicionamento de ar. Quando o ar exterior encontra-se em condições moderadas e condizentes com o sistema de controle definido, a abertura dos registros de controle de vazão (dampers) do ar exterior é modulada, permitindo uma tomada de ar maior que a mínima estabelecida em projeto.

O capitulo 25 da ASHRAE Handbook of Fundamentals (ASHRAE, 2005) define os ciclos economizadores da seguinte maneira:

"Na faixa de operação "economizadora", a unidade distribuidora de ar supre $100 \%$ de ar exterior, mas a unidade de resfriamento está também operando. $\mathrm{Na}$ faixa de operação "sem resfriamento" (free-cooling), a unidade de resfriamento 
não opera e a vazão de ar exterior é modulada para alcançar as cargas térmicas do ambiente. Na faixa de operação "economizadora" e "sem resfriamento" parcial, a vazão do ar exterior será acima da mínima requerida."

Os registros de controle devem ser capazes de modular a vazão do ar exterior e do ar de retorno, possibilitando que até $100 \%$ da quantidade de ar de suprimento projetada para resfriamento possa ser suprida por ar exterior (ASHRAE, 2004d).

O free-cooling significa que nenhum tipo de resfriamento é solicitado para que a temperatura do ar de insuflação seja atingida, e isso acontece apenas quando a temperatura do ar exterior é menor ou igual à temperatura do ar de insuflação.

Operações economizadoras parciais, ou integradas (BAUMAN, 2003) ocorrem quando a temperatura do ar exterior encontra-se entre a temperatura de insuflação e a temperatura do ar de retorno. Dessa forma a vazão de tomada do ar exterior é controlada de maneira integrada com a serpentina de resfriamento.

A vazão de tomada do ar exterior pode ser modulada conforme a temperatura do ar de retorno. Com este tipo de controle, a vazão do ar exterior é configurada para um valor mínimo de projeto sempre que a sua temperatura for maior que a temperatura de retorno. Da mesma maneira, se a temperatura do ar exterior estiver mais baixa que a temperatura do ar de retorno, os registros de controle de vazão do ar exterior permitirão uma maior tomada de ar.

Considerando que o sistema UFAD esteja operando com temperatura de insuflação a $19^{\circ} \mathrm{C}$, as operações de free-cooling são estendidas até a temperatura do ar exterior de aproximadamente $19^{\circ} \mathrm{C}$. Neste caso, as operações economizadores parciais ocorrerão entre a temperatura de insuflação $\left(19^{\circ} \mathrm{C}\right)$ e a temperatura de retorno do sistema (aproximadamente $\left.26^{\circ} \mathrm{C}\right)$.

No sistema UFAD, nota-se que os seguintes fatores são primordiais no potencial de utilização dos ciclos economizadores: as condições climáticas, o sistema de controle do próprio ciclo economizador, e o sistema de controle especificado para conforto térmico no ambiente a ser condicionado. Este último definirá o volume e a temperatura do ar na zona de ocupação, zona média de estratificação, e zona alta do ar de retorno.

As condições climáticas serão favoráveis aos ciclos economizadores quando as temperaturas exteriores forem amenas, estando próximas ou abaixo da temperatura do ar definida para o ambiente, e a umidade não for excessiva. A insuflação de ar com umidade excessiva pode causar desconforto aos usuários, condensação no plenum, e proliferação de microorganismos. 
Portanto, tanto a temperatura como também a umidade do ar exterior devem estar apropriadas. Se a umidade do ar exterior tiver que ser controlada, mesmo se a temperatura do ar exterior estiver apropriada, os ciclos economizadores terão suas operações diminuídas ou até mesmo impedidas. A tolerância de umidade relativa do ar exterior para que este possa ser aproveitado no ciclo economizador dependerá do parâmetro da temperatura do ar estabelecido para a unidade de resfriamento, determinado em projeto, e de como será o ciclo do ar.

\subsubsection{Equipamentos}

Os equipamentos de resfriamento utilizados pelo sistema UFAD são em geral os mesmos utilizados pelo sistema convencional de insuflação pelo teto, diferindo na solicitação e possibilidades de operação.

O consumo de energia dos equipamentos é reduzido, pois estes operam para equilibrar a carga térmica apenas na área ocupada, ignorando as cargas térmicas que permanecem nas áreas superiores.

Estudos realizados por Bauman e Webster (2001) indicam que a redução no consumo de energia do sistema UFAD em relação ao de insuflação convencional pelo teto está associada predominantemente aos seguintes fatores: redução no consumo de energia para resfriamento pela utilização de ciclos economizadores; redução do consumo das unidades de resfriamento pela possibilidade de trabalharem com temperaturas mais elevadas devido às temperaturas de suprimento também serem mais altas $\left(16^{\circ} \mathrm{C}\right.$ a $20^{\circ} \mathrm{C}$ versus $13^{\circ} \mathrm{C}$ para sistemas convencionais pelo teto); e economia de energia em função das menores pressões estáticas dos ventiladores.

Bauman (2003) avalia que a pressão estática de um ventilador central do sistema UFAD, com plenum inferior com pressão positiva, é $25 \%$ mais baixa que em um sistema com insuflação pelo teto, pois elimina as perdas de pressão nos dutos de distribuição, diminuindo a pressão requerida no ventilador. Com esse dado, Webster, Ring e Bauman (2000) analisaram o consumo médio anual de um ventilador de um sistema UFAD com volume de ar variável (VAV) comparado com um sistema com insuflação pelo teto com VAV, e concluiram que os ventiladores no sistema UFAD podem ter seu consumo reduzido em até $40 \%$.

Segundo Bauman e Webster (2001), a economia de energia pelos ventiladores está associada à pressão no plenum inferior, e às possíveis perdas por frestas no piso elevado. 
Em sistemas UFAD com pressão positiva, as pressões estáticas no plenum, segundo Bauman (2003), devem variar entre 12,5 a 25 Pa. Leite (2003) sugere de 8 a $12 \mathrm{~Pa}$.

O sistema com pressão zero, apesar de não sofrer com perdas por frestas, utiliza ventiladores localizados nos difusores, portanto ativos, combinados com a unidade central de distribuição de ar, o que deve ser considerado no consumo energético.

$\mathrm{Na}$ avaliação do consumo de energia por ventiladores há que se considerar a maior vazão de ar requerida nas zonas perimetrais devido às cargas térmicas resultantes da radiação solar na envoltória do ambiente. Isto pode solicitar maiores pressões nos ventiladores ou requerer a instalação de sistemas isolados, tais como sistema dutado trabalhando em conjunto com pequenos ventiladores ou caixas de VAV.

Wang, Arens e Webster (2002) compararam a distribuição de ar pelo piso e pelo teto de um sistema de condicionamento com volume de ar variável (VAV), e concluiram que o consumo de energia para resfriamento no sistema UFAD é $31 \%$ menor, e o consumo dos ventiladores é 5\% maior. Compararam também as distribuições do ar para um sistema de condicionamento com volume de ar constante (VAC) e concluiram que o consumo de energia para resfriamento no sistema UFAD é 29\% menor, e o consumo dos ventiladores é $5 \%$ menor. Os resultados indicam que nas duas configurações do sistema (VAV e VAC) o sistema UFAD reduz $16 \%$ do consumo total de energia em relação ao sistema com distribuição pelo teto.

\subsubsection{Massa térmica}

A utilização da massa térmica para reduzir o consumo de energia de resfriamento é ressaltada por Matsunawa, lizuka e Tanabe (1995) e Bauman (1999).

O aproveitamento da massa térmica do edifício para economia do consumo de energia é uma estratégia que se utiliza do contato direto do ar insuflado no plenum com a camada de concreto para reduzir a demanda de pico e para diminuir a capacidade do equipamento de resfriamento. Em locais onde as condições climáticas permitem, a ventilação noturna do plenum utilizando o ar externo pode pré resfriar a massa térmica substituindo parte da carga sensível a ser retirada pela unidade de resfriamento. Reduções de demanda de energia de pico no verão utilizando a massa térmica podem chegar a $40 \%$ segundo Spoormaker (1990), e 30\% segundo Shute (1995).

Badenhorst (2002) coloca que ao mesmo tempo que a utilização da massa térmica oferece potencial energético, ela também apresenta a possibilidade de condensação no 
plenum, especialmente se o plenum resfriado for repentinamente exposto ao ar úmido e aquecido. Portanto, em climas úmidos é importante que a temperatura de orvalho do ar que entra no plenum seja controlada, e que não haja infiltrações de ar.

\subsubsection{Cargas térmicas}

O cálculo preciso das cargas térmicas a serem retiradas pela unidade de resfriamento é imprescindível para o dimensionamento ideal do sistema.

Webster, Ring e Bauman (2000) colocam que projetar o sistema UFAD considerando isoladamente as cargas térmicas relativas às zonas perimetrais, zonas de ocupação e suas subdivisões, altera os resultados de consumo de energia do sistema. A possibilidade de utilização do sistema de forma híbrida utilizando difusores passivos e ativos de insuflação de ar, assim como sistemas de volume de ar constante e variável num mesmo ambiente podem majorar o desempenho energético do UFAD. Webster, Ring e Bauman (2000) revelam ainda que a estratégia de volume de ar variável (VAV) implementado no sistema UFAD pode resultar em significante economia da energia consumida pela central de ventilação em comparação a sistemas típicos de insuflação pelo teto.

O padrão de estratificação da temperatura do sistema UFAD permite que a maior parte do ganho de calor por convecção originado fora da zona de ocupação possa retornar diretamente no nível do teto e, portanto não ser inclusa nos cálculos de carga (BAUMAN, 2003).

Segundo Bauman (2003), a maior dificuldade ao se projetar um sistema UFAD é a falta de ferramentas precisas para averiguação das cargas térmicas na zona de ocupação e na zona superior, ilustradas na figura 4 (página 12). Pesquisas, tais como de Bauman (2006), buscam o desenvolvimento de métodos para cálculos de carga específicos para o sistema UFAD.

Webster, Bauman e Reese (2002) apud Bauman (2003) colocam que a transferência de calor pelas placas do piso deve ser considerada nos cálculos de carga, pois através de experimentos verificou-se que uma vez controladas as temperaturas do ar do ambiente e do plenum, a transferência de calor do piso reduz as solicitações de fluxo do ar na zona. Tal colocação explica o fato de grande parte dos sistemas estudados por Daly (2002), apud Bauman (2003) apresentarem temperaturas de retorno inferiores às estimadas, o que leva à estratificação reduzida, e aumenta o consumo de energia do sistema. 


\subsubsection{Sensores}

Pesquisas sobre o posicionamento de sensores no sistema UFAD são impulsionadas pelo fato de que o consumo de energia do sistema pode ser reduzido quanto maior for a estratificação do ar no ambiente. Tal estratificação deve ocorrer sem prejudicar a qualidade do ar e o conforto térmico dos ocupantes, não permitindo diferencial de temperatura maior que $3^{\circ} \mathrm{C}$ entre os pés e a cabeça dos mesmos, nem velocidades do ar que possam causar desconforto por correntes de ar.

Wang, Arens e Webster (2002) analisaram a potencialidade de redução do consumo de energia do sistema UFAD em função do posicionamento e quantidade de sensores responsáveis pelo monitoramento dos ambientes. Concluiram que:

a) Uma rede de sensores localizados de forma a controlar a estratificação na zona de ocupação pode reduzir o consumo do sistema;

b) Ajustando tanto a temperatura do ar de suprimento quanto a vazão, uma condição ótima de suprimento de ar pode ser atingida, reduzindo o consumo de energia e mantendo as condições de conforto;

c) As simulações executadas para um edifício típico de escritórios em Sacramento indicaram que a utilização de um sensor de temperatura, instalado a 1,14 $\mathrm{m}$ de altura, reduz em aproximadamente $3 \%$ o consumo de energia se comparado com o mesmo sistema com um sensor localizado a 1,67 $\mathrm{m}$ de altura. Tal redução de consumo pode chegar a $8 \%$ quando dois sensores de temperatura são instalados, um a $0,10 \mathrm{~m}$ de altura e outro a $1,67 \mathrm{~m}$.

\subsubsection{Controle individual}

Pesquisas tais como de Bauman (1999), Tsuzuki et al. (1999), Leite (2003), Leite e Tribess (2004), Song et al. (2004) avaliam o sistema UFAD com controle individual de vazão situado nas estações de trabalho (Task/Ambient Conditioning) nos quesitos conforto térmico e a possibilidade de redução do consumo de energia.

Em laboratório experimental, Leite e Tribess (2004) verificaram quantitativa e qualitativamente que quando de posse do controle individual de vazão os usuários são mais tolerantes em relação à temperaturas do ar ambiente mais elevadas, criando um micro clima em suas estações de trabalho. 
Song et al. (2004) estudaram o conforto térmico proveniente de sistemas de condicionamento de ar com controle individual e seu uso concomitante com insuflação pelo piso. Por meio de medições de temperatura superficial da pele e simulações CFD verificaram que a utilização do controle individual proporciona menor consumo de energia e alivia estímulos térmicos até que o conforto térmico seja alcançado pelos usuários em atividade de 1,2 met.

Bauman (1999) coloca que algumas estratégias para conservação de energia podem ser utilizadas em sistemas UFAD projetados com controle individual. Entre elas, cita-se: redução do condicionamento de ar fora das estações de trabalho, permitindo determinada estratificação térmica no espaço; temperaturas médias mais altas podem ser mantidas devido à movimentação do ar e capacidade de resfriamento aumentados em função dos difusores locais e em resposta ao ciclo diário do ambiente externo. Além disso, a energia consumida por sistemas que utilizem pequenos ventiladores motorizados para suprimento de ar pode ser diminuída com a utilização de sensores de ocupação nas estações de trabalho (nos Estados Unidos estima-se que as estações de trabalho em escritórios de planta livre permaneçam desocupadas em média 50\% do tempo). Segundo Bauman (1999), em simulações feitas para um edifício de escritórios na Baía de São Francisco (EUA), as estratégias para conservação de energia citadas permitiram uma economia de $18 \%$ no consumo de energia por resfriamento, $18 \%$ do consumo por distribuição (ventiladores e bombas) e $10 \%$ do total da eletricidade. 


\section{MÉTODO DE TRABALHO}

A revisão bibliográfica demonstra que vários são os fatores que podem interferir no consumo de energia do sistema UFAD, dentre eles a otimização do controle da tomada de ar externo que, dependendo das condições climáticas locais, permite a utilização de ciclos economizadores para a redução do consumo de energia de tais sistemas.

A análise do potencial de redução do consumo de energia dos sistemas UFAD, na cidade de São Paulo, por meio da utilização de ciclos economizadores, baseou-se em avaliações de resultados obtidos por simulações computacionais efetuadas no programa EnergyPlus.

Para tais simulações foi desenvolvido um modelo baseado em uma câmara de testes representativa de um ambiente de escritórios: o Laboratório Representativo de Ambientes de Escritório da Escola Politécnica de Engenharia da Universidade de São Paulo, desenvolvido por Leite (2003). Esse laboratório representa

"uma fração de um pavimento tipo de edifício de escritórios, cujas características - configuração de layout, tipo de ocupação por pessoas e equipamentos, localização e tipo de envoltória - além de serem as mais repetidas, traduzem as condições reais dos ambientes deste tipo de edificação" (LEITE, 2003).

As seguintes etapas foram necessárias para a elaboração deste trabalho e serão descritas detalhadamente nos sub-itens deste capítulo:

a) Atividades relacionadas ao Programa Computacional EnergyPlus

i. Averiguação da compatibilidade do programa computacional EnergyPlus com o objetivo desta pesquisa;

ii. Análise dos fundamentos e equações utilizados pelo programa.

b) Desenvolvimento do modelo de simulação nos quesitos:

i. Dados climáticos;

ii. Geometria;

iii. Materiais construtivos;

iv. Cargas internas e padrões de ocupação;

v. Vestimenta dos usuários.

c) Elaboração do modelo do sistema de condicionamento de ar para simulação:

i. Especificação dos equipamentos; 
ii. Definição dos circuitos de ar: utilização e não utilização do duto de desvio (bypass) de corrente do ar de retorno. A utilização do desvio do ar de retorno é prática comum nos sistemas UFAD para atingir a temperatura de insuflação requerida pelo sistema, mantendo o controle de umidade;

iii. Em função da utilização ou não do duto de desvio do ar de retorno foram definidas as temperaturas de água e de ar necessárias para que o sistema garantisse a umidade e a temperatura do ambiente dentro das zonas de conforto térmico;

iv. Posteriormente foram analisados e definidos os dados de controle para a utilização do ciclo economizador e do reaproveitamento do ar de retorno.

d) De posse dos dados supracitados, foram definidos os casos para as simulações.

e) Execução de simulações computacionais dos casos visando à análise do consumo de energia.

f) Análise de dados climáticos da cidade de São Paulo.

g) Análise dos modelos simulados:

i. Verificação dos modelos;

ii. Comparação dos resultados (curvas de temperatura do ambiente) gerados pelas simulações com resultados experimentais (curvas obtidas por Leite (2003)) por meio de medições;

iii. Análise das condições de conforto térmico nos modelos.

h) Análise do consumo de energia dos modelos em função da utilização dos ciclos economizadores.

i) Elaboração das conclusões.

\subsection{PROGRAMA COMPUTACIONAL ENERGYPLUS}

As simulações computacionais têm tido grande valor na avaliação e projetos de edificações, pois, à medida em que a capacidade de processamento dos computadores evolui, a trabalhabilidade conjunta de grande quantidade de variáveis em curto espaço de tempo aumenta.

No âmbito do conforto e da eficiência energética, nota-se uma busca incessante no desenvolvimento e implantação de algoritmos e novas equações que melhor traduzam a complexidade dos fenômenos físicos ocorrentes nas edificações. 
Segundo Hensen, Lamberts e Negrão (2002), o desenvolvimento, avaliação, uso em prática e padronização de modelos e programas são de importância crescente, e a integração de métodos e ferramentas é necessária.

Algumas entidades se destacam na disseminação do conhecimento sobre simulações, tais como a International Building Performance Simulation Association (IBPSA), Lawrence Berkeley National Laboratory (LBNL), e o Laboratório de Eficiência Energética em Edificações (LABEEE) da Universidade de Santa Catarina (UFSC).

Neste contexto, o desenvolvimento e aprimoramento de programas de simulação são impulsionados, e podem ser exemplificados: desenvolvimento de controladores para a integração de programas como ESP-r (modelagem térmica) e análises computacionais de dinâmica dos fluidos (CFD - Computational Fluid Dynamics) (MORRISON, 2002); desenvolvimento do programa EnergyPlus baseado nos consagrados programas DOE-2 e BLAST (CRAWLEY et al., 2004); integração entre o EnergyPlus e o COMIS (modelagem de fluxos de ar devido a infiltrações e ventilação natural) (HUANG et al.,1999); e desenvolvimento de interfaces, tais como DesignBuilder, para facilitar a utilização de programas como o EnergyPlus.

A simulação computacional colabora na tomada de decisões por possibilitarem análises, em condições transientes, de possíveis respostas das edificações nos quesitos conforto do usuário e eficiência energética em função de variáveis relativas a: materiais de construção, ocupação, utilização do edifício, equipamentos, sistemas de iluminação, sistemas de energia renovável, sistemas de condicionamento de ar, sistemas de controle, clima local, projeto de arquitetura e tarifação de energia.

A escolha do programa de simulação computacional EnergyPlus como ferramenta é justificada pelos recursos por ele oferecidos, pela disponibilidade do mesmo, e pelo enquadramento do modelo computacional com o objetivo deste trabalho. Os recursos e aplicabilidade do EnergyPlus podem ser verificados no relatório produzido por Crawley et al. (2005), onde há a comparação dos recursos e parâmetros de simulação de vinte dos principais programas de simulação energética de edifícios, dentre eles: BLAST, DOE-2.1E, ECOTECT, EnergyPlus, ESP-r, TAS, TRACE e TRNSYS.

O EnergyPlus, atualmente na versão 2.1.0.023, está em constante desenvolvimento e é resultado da parceria entre o Laboratório Nacional Lawrence Berkeley, Universidade de Illinois, Laboratório de Pesquisa de Engenharia de Construção das Forças Armadas dos Estados Unidos, Gard Analytics, Inc., Universidade do Estado de Oklahoma, com suporte do Departamento de Energia dos Estados Unidos, Escritório de Tecnologia das Edificações, 
Programas do Estado e da Comunidade, sendo os direitos autorais do Departamento de Energia dos Estados Unidos.

O EnergyPlus permite a modelagem e simulação de sistemas de aquecimento, resfriamento, iluminação, ventilação, e avaliações energéticas. É basicamente um conjunto de sistemas modulares integrados, suscintamente descritos a seguir. A figura 5 indica o esquema dos módulos integrados disponíveis no programa.

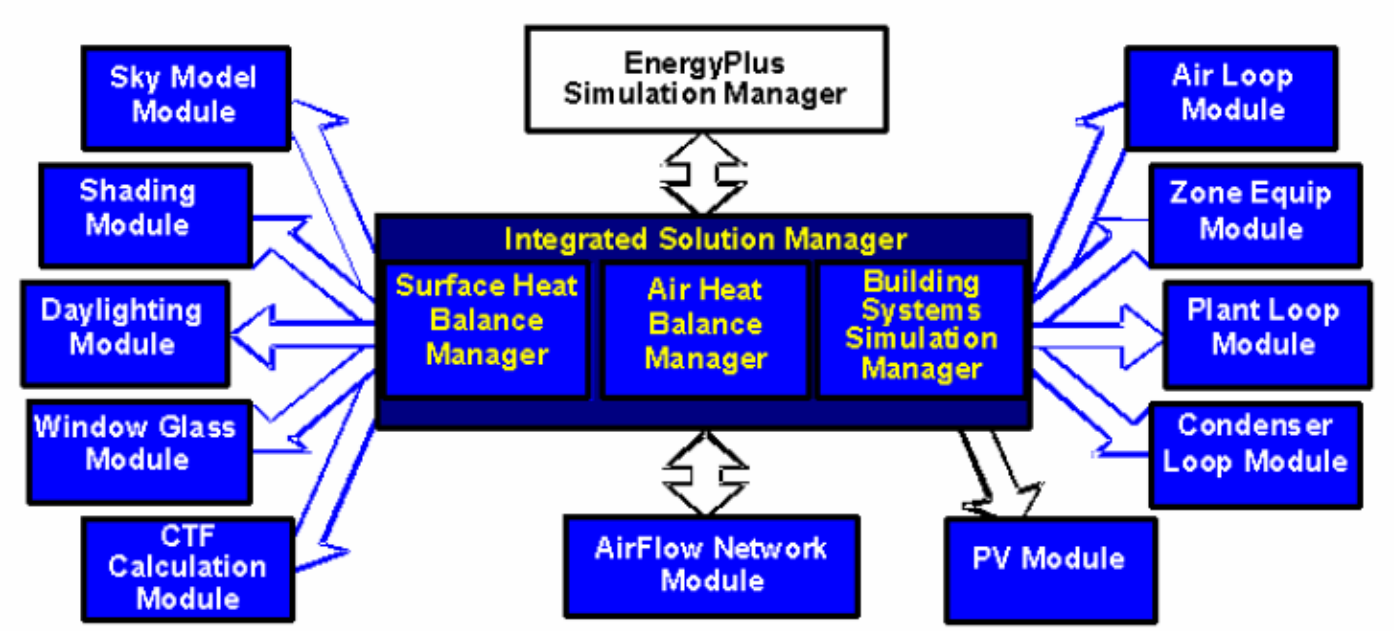

Figura 5 - Esquema dos Módulos do EnergyPlus. Fonte: EnergyPlus (2006).

O EnergyPlus possui dois módulos básicos: o simulador de balanço térmico e de massa e o simulador dos sistemas do edifício. O gerenciador do simulador dos sistemas do edifício encarrega-se da comunicação entre os cálculos de balanço térmico e vários módulos e "circuitos" do sistema de condicionamento de ar, tais como serpentinas, unidades de aquecimento, unidades de resfriamento, bombas, ventiladores, e outros equipamentos. $\mathrm{O}$ gerenciador do balanço térmico e de massa atua nos módulos de balanço térmico de superfícies e ar e atua como uma interface entre o balanço térmico e o gerenciador do simulador dos sistemas do edifício. O módulo do balanço térmico de superfícies simula balanços internos e externos, relações com diferentes condições de contorno, e efeitos de condução, convecção, radiação e transferência de massa. O módulo de balanço de massa simula as vazões de ar (ventilação, exaustão e infiltração) considerando massas térmicas das zonas de ar e cargas térmicas de convecção. Modelos para simulação de iluminação natural, janelas e desempenho de envoltórias estão incorporados no EnergyPlus, possibilitando análises de iluminância proporcionada pela luz natural, controle de ofuscamento, e controles de iluminação artificial. (CRAWLEY et al., 2005) 
O EnergyPlus executa cálculos numéricos baseados nos princípios fundamentais de balanço de massa e energia e permite simulações integradas de cargas térmicas e sistemas em regime transiente. As três partes principais da simulação - edifício, sistema e planta - são solucionadas simultaneamente, o que proporciona resultados precisos de temperatura e predição de conforto. Nos programas em que o EnergyPlus foi baseado, DOE-2.1E e BLAST, as soluções são executadas de maneira sequencial, ou seja, sem simultaneidade e integração das simulações, não proporcionando o "feedback" entre as partes. No EnergyPlus todos os elementos são integrados e controlados por um gerenciador integrado de soluções, o Integrated Solution Manager (figura 5). Os "circuitos" são divididos entre lado de demanda e suprimento, e o esquema de soluções baseia-se em iterações sucessivas para conciliar suprimento e demanda (EnergyPlus, 2006).

As soluções integradas proporcionam maior acurácia na predição da temperatura no espaço, além de permitir aos usuários avaliar de forma realística: os controladores do sistema, adsorção e dissorção de umidade nos elementos do edifício, sistemas radiantes de aquecimento e resfriamento, e fluxo de ar entre zonas (CRAWLEY et al., 2005).

\subsubsection{Validação do EnergyPlus}

A preocupação com a confiabilidade dos resultados de simulações computacionais desencadeia pesquisas baseadas em análises comparativas entre resultados empíricos e de simulações, e entre resultados de diferentes simuladores.

Neste contexto, testes comparativos com intuito de validar e aprimorar o EnergyPlus foram efetuados pelo "Ernest Orlando Lawrence Berkeley National Laboratory" (2004, 2004a, 2005), para o Departamento de Energia dos Estados Unidos. Tais testes baseiam-se no Building Energy Simulation Test (BESTEST) (INTERNATIONAL ENERGY AGENCY, 1995), no HVAC BESTEST (NEYMARK; JUDKOFF, 2002) e na ANSI/ASHRAE Standard 140-2004 (ASHRAE, 2004a) e indicam que o EnergyPlus computa soluções razoáveis tanto em comparação com outros programas de simulação como na comparação entre casos modelados.

O BESTEST é um projeto conduzido pelo Grupo de Especialistas da Agência Internacional de Energia para Avaliação e Desenvolvimento do Modelo (Model Evaluation and Improvement International Energy Agency (IEA) Experts Group) e tem como objetivo desenvolver a implementação prática de procedimentos e dados para uma metodologia de 
validação de programas de simulação que é desenvolvida pelo "National Renewable Energy Laboratory - NREL" desde 1981.

Tanto o BESTEST quanto o HVAC BESTEST documentam verificações analíticas e procedimentos de diagnósticos comparativos para testar a habilidade de todo o programa de simulação do edifício, sendo que o HVAC BESTEST foca na modelagem do desempenho do equipamento de resfriamento do espaço unitário que é tipicamente modelado utilizando dados de fabricantes derivados de curvas de desempenho empíricas. Resultados comparativos de vários programas de simulação de edifícios que participam do projeto da IEA são apresentados, e testes analíticos comparam os resultados das simulações dos programas com soluções matemáticas para casos simples.

A norma ANSI/ASHRAE Standard 140-2004 (ASHRAE, 2004a) - "Standard Method of Test for the Evaluation of Building Energy Analysis Computer Programs" é baseada no BESTEST e pode ser utilizada para identificar e diagnosticar diferenças de predição entre programas de simulação de energia de edificações.

\subsubsection{EnergyPlus e o modelo UFAD}

Os modelos de ar no programa EnergyPlus foram desenvolvidos para representar ambientes com distribuição não uniforme de temperatura, tais como sistemas com ventilação por deslocamento, ventilação cruzada, e sistemas UFAD.

Tais modelos consideram apenas a distribuição de temperaturas no ambiente, permitindo cálculos de transferência de calor e balanços térmicos do sistema de ar, considerando o fenômeno de estratificação natural do ar e diferentes tipos de sistemas de distribuição.

No EnergyPlus, para a simulação adequada do sistema UFAD foi implementado o modelo "UCSD UFAD interior model control". É aplicável a espaços interiores sem incidência de radiação solar, tendo como fontes predominantes de calor as pessoas, os equipamentos e outras fontes localizadas na zona ocupada do ambiente. Este modelo foi desenvolvido por Liu (2006), da Universidade da Califórnia, em San Diego (UCSD), que executou validações do mesmo, comparando as simulações numéricas com dados medidos em câmara de testes.

Com o "UCSD UFAD interior model control" o ambiente condicionado é modelado em duas zonas bem definidas (figura 6): 
a) zona ocupada, com sua temperatura $\left(\mathrm{T}_{\mathrm{OZ}}\right)$ representando a temperatura na região entre o piso e o limite da zona superior;

b) zona superior, com sua temperatura $\left(\mathrm{T}_{\mathrm{MX}}\right)$ essencial para os cálculos de consumo de energia e para a simulação dos efeitos de conforto proporcionados por esta camada.

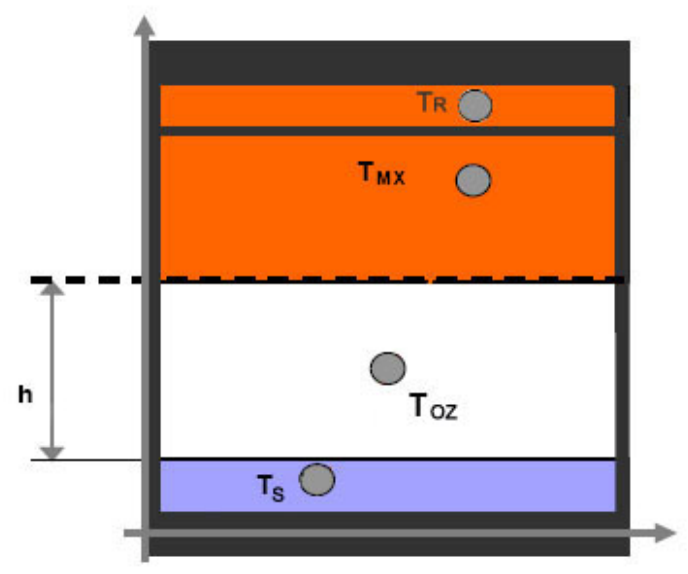

Figura 6 - Subzonas do sistema "UCSD UFAD interior model control".

O limite entre as duas zonas se move para cima ou para baixo a cada passo de simulação, como resultado das cargas térmicas do ambiente e da vazão do ar insuflado. Portanto, para cada passo de simulação, a altura e balanços de calor convectivo são recalculados separadamente para cada subzona, assim como as porções de superfícies correspondentes a cada uma.

O modelo, detalhamente descrito por Liu (2006) e pelo Center for the Built Environment (2007), e implementado no EnergyPlus, é baseado nas seguintes equações:

$$
\begin{aligned}
& T_{r}=\frac{0,0281 W}{Q g} T_{s}+T_{s} \\
& T_{o z}=T_{r}-1,6 \Gamma^{-0,76}\left(T_{r}-T_{s}\right) \\
& h=\sqrt{\frac{n}{m} A(7,43 \ln (\Gamma)-1,35)+\frac{1}{2} h_{s}}
\end{aligned}
$$


Onde:

$T_{r}$ - temperatura de retorno $(\mathrm{K})$,

$T_{o z}$ - temperatura do ar na zona ocupada $(\mathrm{K})$,

$h$ - altura de interface entre as duas subzonas (m),

$T_{\mathrm{s}}$ - temperatura do ar de suprimento $(\mathrm{K})$,

$n$ - número de difusores,

$m$ - número de fontes de calor;

$h_{s}$ - posição vertical da fontes de calor (m);

$W$ - carga térmica $(\mathrm{kW})$,

$A$ - área efetiva do difusor $\left(\mathrm{m}^{2}\right)$,

$Q$ - vazão total de ar de suprimento $\left(\mathrm{m}^{3} / \mathrm{s}\right)$,

$g$ - gravidade $\left(\mathrm{m} / \mathrm{s}^{2}\right)$,

$\Gamma$ - definido pela equação (4), representa o efeito da convecção e o momento gerado pelos jatos de ar dos difusores do tipo espiralados (swirl).

$$
\Gamma=\frac{(Q \cos \theta)^{3 / 2}}{m(n A)^{5 / 4}(0.0281 W)^{1 / 2}}
$$

Onde $\theta$ é o ângulo entre a abertura do difusor e a direção vertical.

\subsubsection{EnergyPlus e o sistema de condicionamento de ar}

No EnergyPlus o sistema de condicionamento de ar é simulado segundo circuitos de ar, água e condensadores (figura 7). Os circuitos são formados por ramais compostos por componentes que se distribuem em série ao longo de um duto de ar ou tubulação de água. Os componentes são equipamentos do sistema de condicionamento de ar e são interligados por pontos que definem as entradas e saídas dos mesmos, assim como o começo e fim de cada ramal.

Os circuitos consideram os lados de demanda e suprimento e são explanados resumidamente a seguir:

a) Circuito de ar - onde ocorre o condicionamento do ar antes de ser distribuído para as zonas definidas na geometria do modelo; 
b) Circuito dos equipamentos da zona - equipamentos mais específicos a cada zona térmica compõem este circuito. No caso do modelo gerado neste trabalho, o equipamento que compõe este circuito é a unidade de distribuição de ar;

c) Circuito do lado da demanda da planta - é onde a serpentina requisita fluido refrigerado para propiciar resfriamento para as zonas, ou seja, para a demanda. Conecta-se ao circuito de ar ou ao circuito dos equipamentos das zonas através de componentes individuais, e ao lado de suprimento da planta através da conexão direta com o fluido;

d) Circuito do lado de suprimento da planta - fornece fluido refrigerado para atender o lado da demanda da planta. Nele estão a bomba e o chiller. Este circuito geralmente controla tanto a vazão do fluido (via bomba) quanto a sua temperatura. Conecta-se diretamente ao lado de demanda da planta e, indiretamente, com o lado da demanda do condensador por meio de componentes;

e) Circuito do lado de demanda do condensador - recebe a rejeição de carga térmica do equipamento do lado de suprimento da planta;

f) Circuito do lado do suprimento do condensador - fornece o fluido refrigerado para o lado da demanda do condensador.

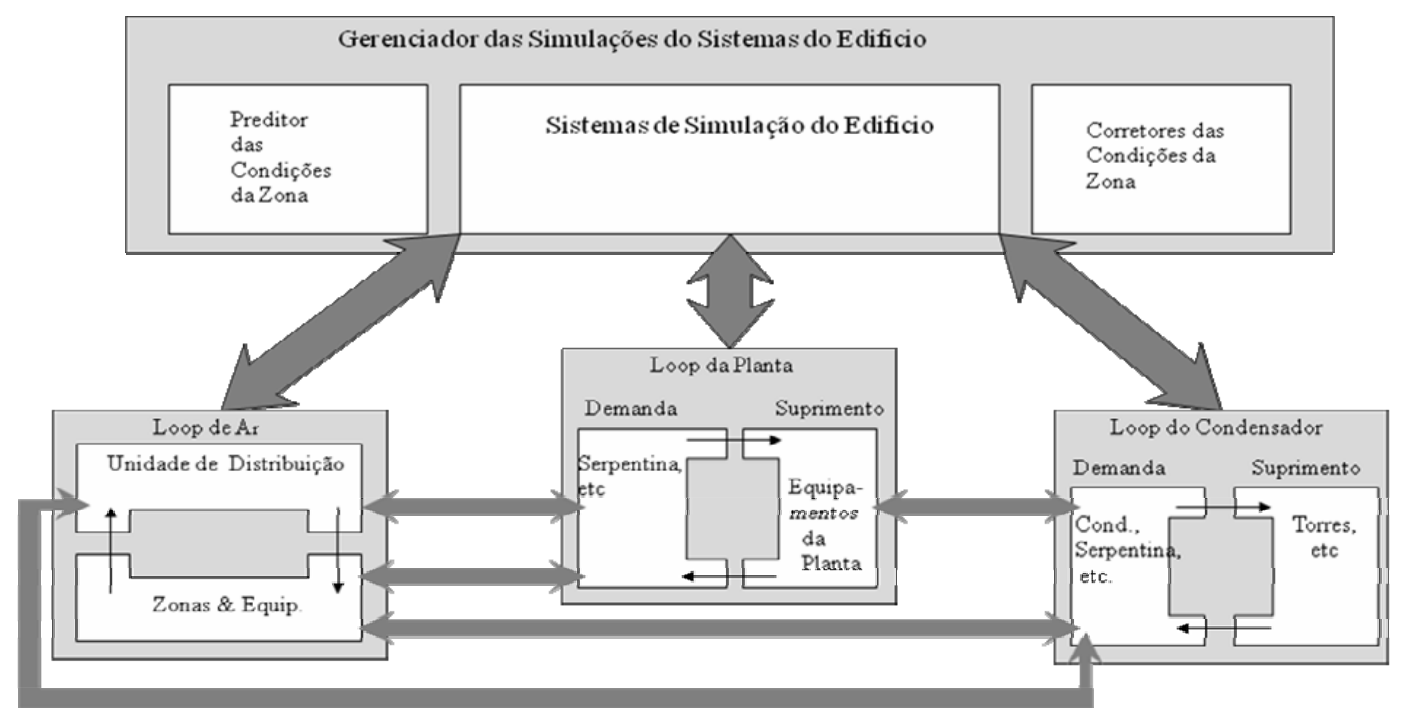

Figura 7 - Interação dos circuitos do sistema de condicionamento de ar no EnergyPlus. Fonte: GARD ANALYTICS, INC. E UNIVERSITY OF ILLINOIS (2002-2003). 


\subsubsection{EnergyPlus e o ciclo economizador}

O EnergyPlus permite o controle da tomada do ar exterior em função dos ciclos economizadores. Possibilita a configuração das operações economizadoras, economizadoras parciais e de free-cooling.

Os ciclos economizadores são caracterizados pela modulação da tomada de ar exterior por meio de registros (dampers) que são acionados segundo limites relacionados às condições climáticas, controle do sistema e do ambiente. A vazão do ar exterior é controlada pela combinação dos parâmetros estabelecidos para o circuito de água e ar com os limites de atuação dos ciclos economizadores.

O controle da vazão da tomada do ar exterior pode ser realizado por meio da definição de:

a) Temperaturas de bulbo seco do ar exterior máxima e mínima. Quando a temperatura de bulbo seco do ar exterior estiver entre a mínima e a máxima estabelecidas, a utilização de maior vazão de ar exterior será permitida;

b) Entalpia do ar exterior. Se a entalpia do ar exterior estiver superior à estabelecida, a vazão do ar exterior será limitada ao valor mínimo estabelecido;

c) Entalpia do ar de retorno. Se a entalpia do ar de retorno estiver menor que a entalpia do ar exterior, a vazão do ar exterior será limitada ao valor mínimo estabelecido;

d) Temperatura do ar de retorno. Se a temperatura do ar de retorno estiver menor que a temperatura do ar exterior, a vazão do ar exterior será limitada ao valor mínimo estabelecido.

Com a atuação destes controles, a vazão de ar exterior é modulada de maneira que as condições do ar na caixa de mistura do ar exterior permitam que o sistema de condicionamento do ar atinja o conforto térmico no ambiente. A maneira como a vazão de ar exterior é modulada será explicada a seguir.

No EnergyPlus, os registros de controle de vazão do expurgo do ar de retorno e tomada de ar exterior, as operações economizadoras e qualquer equipamento de condicionamento do ar externo, formam um subsistema separado do sistema central de ar.

A mistura do ar exterior com o ar de retorno acontece numa caixa virtual, aqui denominada caixa de mistura do sistema do exterior. O gerenciador do parâmetro (setpoint) da caixa de mistura do sistema do ar exterior tem como atuador o registro de controle de vazão do ar exterior. Este controle é função não somente da temperatura do ar exterior, mas, 
também, da temperatura estabelecida para suprimento do sistema principal de ar (temperatura de insuflação do ar no ambiente).

Os pontos de entrada e saída do ventilador de suprimento são dados necessários para os cálculos do EnergyPlus. Com essas informações o gerenciador do setpoint da caixa de mistura do sistema do ar exterior calcula o aumento de temperatura do ar no ventilador de suprimento e o subtrai do setpoint da temperatura de referência, e usa o resultado como o setpoint da caixa de mistura do sistema do ar externo.

Por exemplo, quando o ciclo economizador está atuando com controles de temperatura de bulbo seco, se a temperatura do ar exterior for igual ou maior que a temperatura na caixa de mistura do ar exterior, a vazão de ar exterior será configurada para o valor mínimo; se a temperatura do ar exterior for menor que a temperatura de setpoint da caixa de mistura do ar exterior, então o controlador do ar externo irá modular a vazão de ar externo de maneira que a temperatura do ar da mistura alcance o setpoint desejado. Se todos os limites forem satisfeitos, o controlador atua nos ventiladores cíclicos da seguinte maneira: a vazão de ar externo é configurada para o máximo quando o ventilador estiver ligado. Se os limites não forem satisfeitos, a vazão de ar externo é configurada para o mínimo.

\subsection{DESENVOLVIMENTO DO MODELO}

Os dados utilizados para geração do modelo no programa EnergyPlus consideram: elementos construtivos, geometria e cargas térmicas internas do "Laboratório Representativo de Ambiente de Escritórios" (LEITE, 2003); dados complementares de fornecedores dos materiais de construção do mesmo; normas técnicas; ASHRAE Handbook of Fundamentals (ASHRAE, 2005), e o manual do programa de simulação do EnergyPlus (EnergyPlus, 2006).

Para obter resultados anuais sobre o consumo de energia dos modelos, as simulações foram realizadas para o período de um ano típico do clima da cidade de São Paulo. Fez-se necessária a definição do comportamento ao longo do ano de dados tais como: dados climáticos, densidade de ocupação, vestimenta dos usuários, período de utilização e carga de iluminação artificial, atividade de ocupação, utilização e carga de equipamentos (computadores), disponibilidade dos equipamentos de condicionamento de ar, especificação de dados de controle, entre outros a serem arrolados em itens específicos. 


\subsubsection{Dados climáticos}

As simulações foram executadas para um ano típico da cidade de São Paulo e utilizaram os dados climáticos do arquivo BRA_Sao.Paulo-Congonhas_SWERA.epw da base de dados do projeto "Solar and Wind Energy Resource Assessment" (SWERA), fundado pelo "United Nations Environment Program". Este arquivo utiliza o ano metereológico típico (Typical Metereological Year - TMY) resultante de medições realizadas por dezoito anos, anteriores a 2005. O TMY considera medições horárias de temperatura e umidade do ar, e radiação solar, e os meses com o menor desvio do valor médio das medições compõem o TMY.

\subsubsection{Geometria}

O modelo foi geometricamente gerado conforme o "Laboratório Representativo de Ambiente de Escritórios", definindo-se, em corte, as três zonas físicas típicas de um ambiente com sistema UFAD instalado:

a) Plenum inferior de insuflação - dimensões: 5,27 x 6,60 x 0,25m;

b) Ambiente a ser condicionado - dimensões: 5,27 x 6,60 x 2,68 m; área de 34,78 $\mathrm{m}^{2}$;

c) Plenum superior de retorno - dimensões: 5,27 x 6,6 x 0,54 m.

$\mathrm{O}$ ambiente a ser condicionado pode ser dividido em: zona de trabalho, zona periférica e zona de circulação. A zona periférica não foi considerada neste trabalho; entretanto, este assunto será discutido no item 3.2.4, "Cargas Térmicas".

A figura 8, gerada por simulação no EnergyPlus, ilustra a geometria do modelo.

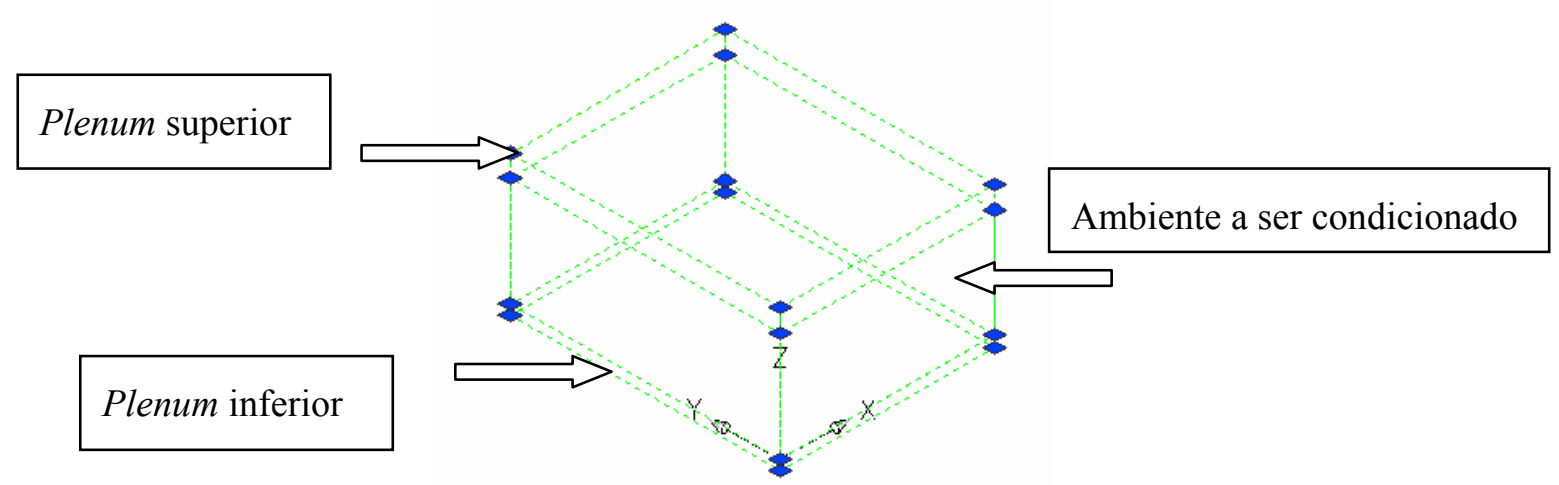

Figura 8 - Geometria do modelo gerada no EnergyPlus. 
As figuras 9 e 10 ilustram o "Laboratório Representativo de Ambiente de Escritórios", e portanto a geometria do modelo computacional simulado.

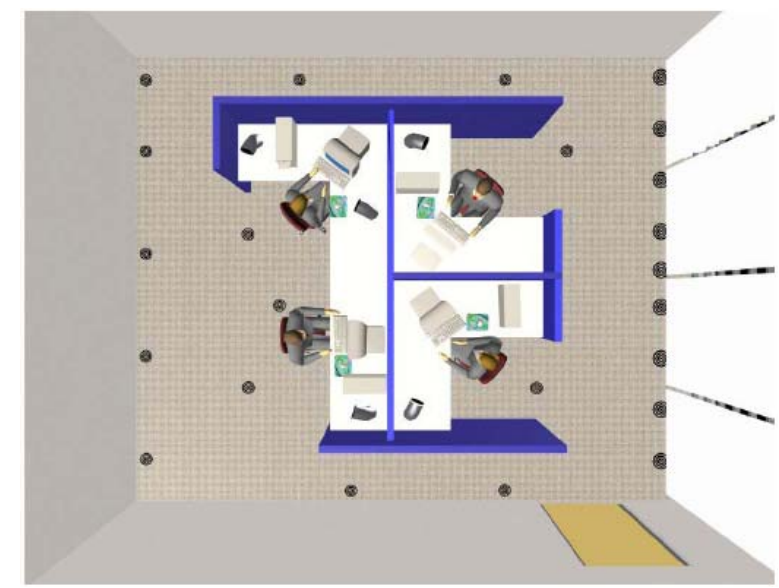

Figura 9 - Perspectiva do Laboratório Representativo de Ambientes de Escritório (LEITE, 2003)

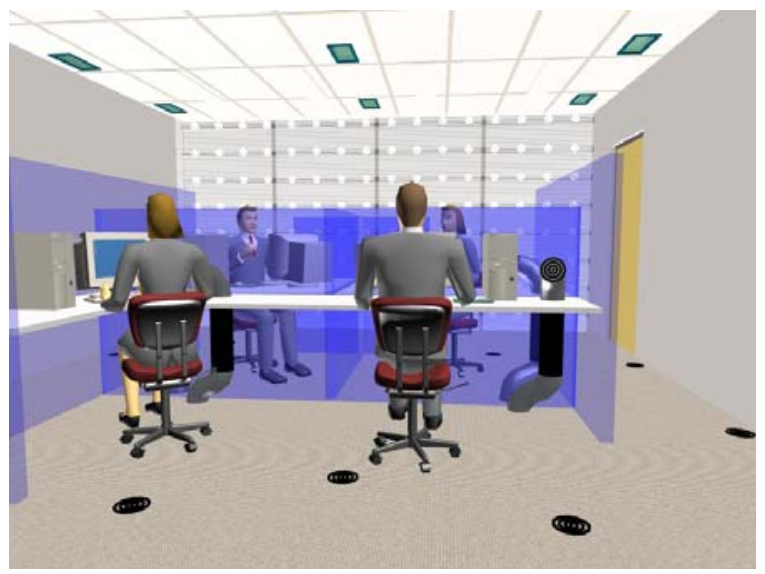

Figura 10 - Perspectiva do Laboratório Representativo de Ambientes de Escritório (LEITE, 2003)

\subsubsection{Materiais componentes}

$\mathrm{Na}$ tentativa de obter um ambiente adiabático, as lajes e paredes limitantes foram modeladas com isolamento térmico por placas de poliuretano de camadas espessas para impossibilitar a troca de calor entre o ambiente e o meio externo por meio da envoltória.

As paredes foram revestidas internamente com chapas de material melamínico. O forro é metálico modular de dimensões 1,20 x 0,60 m, sem perfurações. O piso é elevado e 
composto por placas moduladas e intercambiáveis, apoiadas em pedestais metálicos e revestidas com carpete em placas.

Dados relevantes dos materiais que compõem as paredes, lajes, piso elevado e forro estão dispostas na tabela 1 .

Tabela 1- Dados dos materiais de construção.

\begin{tabular}{|c|c|c|c|c|c|}
\hline & $\begin{array}{r}\text { Resistência } \\
\text { térmica } \\
\left(\mathrm{m}^{2} \cdot \mathrm{K} / \mathrm{W}\right)\end{array}$ & Espessura (m) & $\begin{array}{r}\text { Condutividade } \\
(\mathrm{W} / \mathrm{m} . \mathrm{K})\end{array}$ & $\begin{array}{r}\text { Densidade } \\
\left(\mathrm{kg} / \mathrm{m}^{3}\right)\end{array}$ & $\begin{array}{r}\text { Calor } \\
\text { específico } \\
(\mathrm{J} / \mathrm{kg} . \mathrm{K})\end{array}$ \\
\hline $\begin{array}{l}\text { Isolante térmico } \\
\text { de poliuretano }\end{array}$ & - & 0,210 & 0,023 & 24 & 1590 \\
\hline $\begin{array}{l}\text { Forro Metálico } \\
\text { não Perfurado }\end{array}$ & - & 0,003 & 52 & 7780 & 448 \\
\hline $\begin{array}{l}\text { Placa de Piso } \\
\text { Elevado }\end{array}$ & 0,65 & - & - & - & - \\
\hline Carpete & 0,37 & - & - & - & - \\
\hline $\begin{array}{l}\text { Revestimento } \\
\text { Melamínico }\end{array}$ & - & 0,005 & 0,072 & 480 & 1380 \\
\hline
\end{tabular}

\subsubsection{Cargas térmicas}

As simulações consideraram as cargas térmicas internas conforme a configuração utilizada por Leite (2003) no referido laboratório, e os padrões de ocupação foram adaptados especialmente para esta pesquisa, considerando a rotina de um ambiente de escritórios:

a) 4 pessoas sentadas em atividade leve de escritórios e metabolismo equivalente a 70 $\mathrm{W} / \mathrm{m}^{2}$ (1,2 Met), ou $126 \mathrm{~W}$ por pessoa. A ocupação é de segunda a sexta-feira, sendo $25 \%$ de ocupação no período das 8 às 9 horas e das 18 às 19 horas, 50\% das 12 às 14 horas (horário previsto para almoço), e 100\% das 9 às 12 horas e das 14 às 18 horas.

b) 16 lâmpadas fluorecentes com reatores eletrônicos totalizando carga térmica de 696 W. São utilizadas de segunda a sexta-feira, sendo que $25 \%$ das lâmpadas são ligadas no período das 8 às 9 horas e das 18 às 19 horas, 50\% das 12 às 14 horas, e $100 \%$ das lâmpadas são ligadas no período das 9 às 12 horas e das 14 às 18 horas. 
c) 4 computadores totalizando carga térmica de $390 \mathrm{~W}$. São utilizados de segunda a sexta-feira, tendo $25 \%$ de utilização no período das 8 às 9 horas e das 18 às 19 horas, e $100 \%$ das 9 às 18 horas.

A distribuição das cargas internas pode ser visualizada na tabela 2.

Tabela 2 - Distribuição das cargas internas.

\begin{tabular}{lrrrr}
\hline Hora & \multicolumn{3}{c}{ Carga interna em Watts } & \\
\hline $8 \mathrm{~h}$ às $9 \mathrm{~h}$ & Pessoas & Iluminação & Equipamentos & Total \\
$9 \mathrm{~h}$ às12h & 126 & 696 & 97 & 919 \\
$12 \mathrm{~h}$ às $14 \mathrm{~h}$ & 504 & 696 & 390 & 1590 \\
$14 \mathrm{~h}$ às $18 \mathrm{~h}$ & 252 & 696 & 390 & 1338 \\
$18 \mathrm{~h}$ às $19 \mathrm{~h}$ & 504 & 696 & 390 & 1590 \\
& 126 & 696 & 97 & 919 \\
\hline
\end{tabular}

No intuito de analisar a influência da tomada de ar exterior no consumo de energia do sistema UFAD, o modelo para simulação foi desenvolvido de maneira a considerar apenas as cargas internas do ambiente. A radiação solar e a carga térmica proveniente da mesma foram desconsideradas.

A necessidade de considerar apenas as cargas internas e desconsiderar as cargas resultantes da incidência de radiação solar foi gerada em função do tipo de análise proposta. Se as cargas resultantes das zonas perimetrais fossem consideradas, a vazão de ar requerida pelo sistema HVAC seria alterada para equilibrar estas cargas. Isto alteraria também a vazão de tomada do ar exterior caso as condições climáticas estivessem favoráveis às operações dos ciclos economizadores. Dessa maneira, a vazão da tomada de ar exterior não seria mais função apenas das condições climáticas, mas também função da transitoriedade das cargas resultantes da incidência de radiação solar. Desconsiderando as cargas térmicas resultantes da incidência de radiação solar, as cargas térmicas internas são conhecidas e calculadas conforme o padrão de uso do ambiente.

Portanto, para simplificação do modelo e visto que o interesse desta pesquisa é analisar, ao longo do ano, as influências do clima na vazão de tomada do ar exterior, a transitoriedade das cargas térmicas proveniente das zonas perimetrais foi desconsiderada. Além disso, a incidência de radiação solar nas edificações é resultante de questões de projeto, tais como: proteções solares nas fachadas, fator solar dos vidros e orientação solar.

As cargas térmicas resultantes da incidência de radiação solar ficam concentradas principalmente nas zonas perimetrais. No sistema UFAD, é recomendável, e já prática de 
mercado, que estas zonas possuam tratamento de condicionamento de ar diferenciado das zonas interiores.

\subsubsection{Vestimenta dos usuários}

Nas simulações, foram solicitados relatórios da sensação de conforto térmico dos usuários, segundo a escala proposta por Fanger (1972), no intuito de verificar se as condições de conforto térmico foram proporcionadas ao ambiente pelo sistema UFAD.

Os dados para a simulação do conforto térmico consideraram as vestimentas dos usuários comumente utilizadas nos escritórios no Brasil:

a) 0,7 clo no verão, equivalente a composição com roupas leves: roupas íntimas, calças / saias, blusas de algodão, poliéster ou mistas, de manga curta ou comprida;

b) 1,0 clo no inverno, equivalente à mesma composição utilizada no verão, acrescida de um paletó de tecido leve.

\subsection{DESENVOLVIMENTO DO MODELO DO SISTEMA DE CONDICIONAMENTO DE AR}

Para a modelagem do sistema de condicionamento de ar foram utilizados dados do projeto de ar-condicionado do laboratório de referência, ASHRAE Handbook of Fundamentals (ASHRAE, 2005), a ASHRAE Standard 90.1 (ASHRAE, 2004d), a Resolução RE ANVISA N9 (BRASIL, 2003), a ASHRAE Standard 55 (ASHRAE, 2004b), a ASHRAE Standard 62.1 (ASHRAE, 2004c) e os princípios de funcionamento do sistema UFAD.

\subsubsection{Especificação dos equipamentos}

O projeto de condicionamento de ar do Laboratório foi utilizado como referência para elaboração do modelo. Tanto cálculos numéricos quanto simulações computacionais foram realizados para dimensionar os equipamentos, e seus resultados foram comparados para efeito de verificação do modelo.

No intuito de possibilitar a análise comparativa entre os resultados dos casos simulados (em número de seis e detalhados no item 3.4 deste capítulo) as especificações dos equipamentos foram as mesmas em todos os modelos. Para tal, os casos foram simulados, 
inicialmente, com todos os equipamentos configurados para atender à demanda de acordo com o dimensionamento do programa computacional.

Os resultados do dimensionamento dos equipamentos de todas as simulações iniciais foram comparados entre si e, verificadas as diferenças, os equipamentos com maior dimensionamento foram utilizados como parâmetros para as simulações finais.

Este procedimento foi adotado para que em todas as simulações o sistema de condicionamento de ar disponibilizasse a mesma capacidade de refrigeração e fosse capaz de atender à demanda.

Os resultados destas simulações iniciais foram utilizados para a especificação dos valores de capacidade nominal da unidade de resfriamento, capacidade nominal do motor da bomba e sua vazão máxima de água. Tais dados foram fixados em todos os casos simulados, e os resultados são apresentados no item "Verificação do dimensionamento dos equipamentos", do Capítulo 4.

Alguns parâmetros, necessários para os dimensionamentos, foram estabelecidos tendo como base as especificações do projeto de condicionamento de ar do Laboratório. Os equipamentos especificados foram:

a) Unidade de Resfriamento de Água acionada Eletricamente, com condensação a ar, coeficiente de performance nominal (COP) igual a 3,2, e vazão variável;

b) Bomba, com altura manométrica de $15 \mathrm{mca}$, com controle intermitente.

c) Serpentina de resfriamento à água, com vazão variável.

d) Ventiladores de insuflação e de retorno, altura manométrica $100 \mathrm{~Pa}$, com vazão de ar variável.

e) Total de 14 difusores de ar com jato espiralado (swirl), com $15 \mathrm{~cm}$ de diâmetro.

Todos os equipamentos estão controlados para entrar em funcionamento uma hora antes da ocupação do ambiente, ou seja, estão disponibilizados entre as $7 \mathrm{~h}$ e $19 \mathrm{~h}$.

\subsubsection{Circuitos de ar e modos de operação}

O sistema UFAD pode operar de duas maneiras distintas para que o ar de insuflação atinja a temperatura e umidade desejadas. Essas maneiras diferem na utilização ou não de um duto para desvio (bypass) de ar de retorno, e serão explanadas a seguir. 


\subsubsection{Circuito de ar com desvio de ar (bypass) de retorno}

O duto para desvio de ar de retorno (figura 11) é utilizado para propiciar o reaproveitamento deste ar para reaquecimento do ar de insuflação, e é passível de utilização em função das temperaturas de insuflação do sistema UFAD serem mais elevadas que em sistemas com distribuição pelo teto.

Com o duto de desvio, apenas a composição do ar exterior e parte do ar de retorno passa pela serpentina de resfriamento, que tem como função garantir a desumidificação do ar e contribuir para se atingir a temperatura do ar de insuflação. Para tanto, a temperatura do ar após passar pela serpentina é controlada entre $10^{\circ} \mathrm{C}$ e $13^{\circ} \mathrm{C}$ (Bauman, 2003), e o ar resfriado é adicionado ao ar de retorno resultando na mistura que será insuflada no ambiente. Os registros de vazão (dampers) do ar de retorno, do volume de ar a ser expurgado, de tomada de ar exterior e de volume de ar a ser condicionado são, portanto, controlados para atingir a temperatura de insuflação desejada.

O circuito de ar para simulação dos modelos com desvio do ar de retorno foi modelado da seguinte forma, e pode ser visualizado nos esquemas das figuras 11 e 12:

a) $\mathrm{O}$ ventilador de retorno retira o ar do plenum superior e o insufla num duto que se divide em duas ramificações com registros de controle de vazão automatizados: a ramificação que envia o ar para o, aqui denominado, sistema do ar exterior; e o duto de desvio (bypass). Em sua totalidade, o ar de retorno é dividido em três frações: a ser expurgada, a ser novamente condicionada, e a ser reutilizada sem condicionamento. As duas primeiras frações concentram-se no sistema do ar exterior, e a terceira fração passa pelo duto de desvio do ar de retorno.

b) No sistema do ar exterior ocorrem as operações de: expurgo de parte do ar de retorno, tomada de ar exterior, e mistura deste último com o restante da fração do ar de retorno. Essa mistura de ar é encaminhada para a serpentina de resfriamento, onde ocorre seu condicionamento.

c) O ar condicionado é então conduzido para uma caixa onde ocorrerá a sua mistura com a fração do ar de retorno não condicionado.

d) Tal mistura é então conduzida ao plenum inferior por meio do ventilador de insuflação e os difusores instalados no piso elevado se encarregam da distribuição do ar no ambiente, reiniciando-se o ciclo do ar.

A figura 11 indica esquematicamente a distribuição de ar acima descrita, e a figura 12 indica um corte esquemático do sistema. 


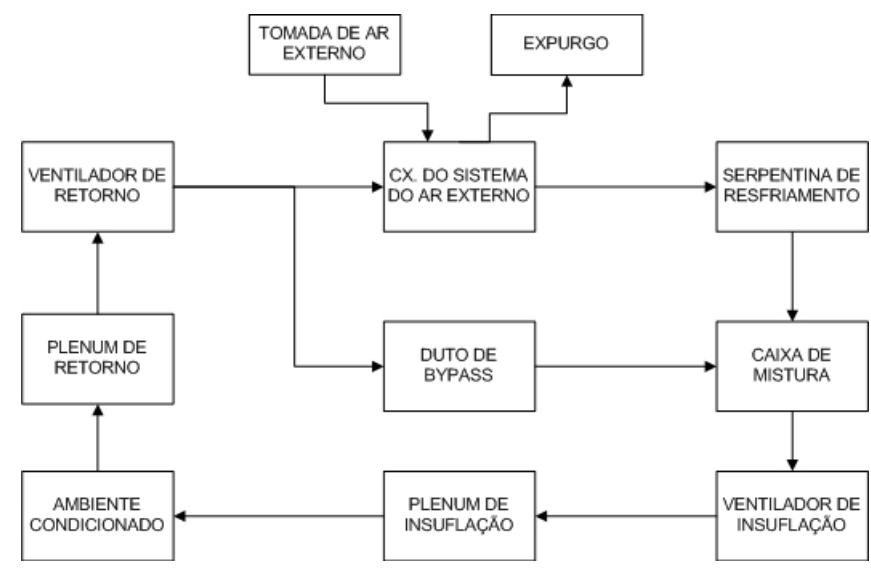

Figura 11 - Circuito com desvio de ar de retorno.

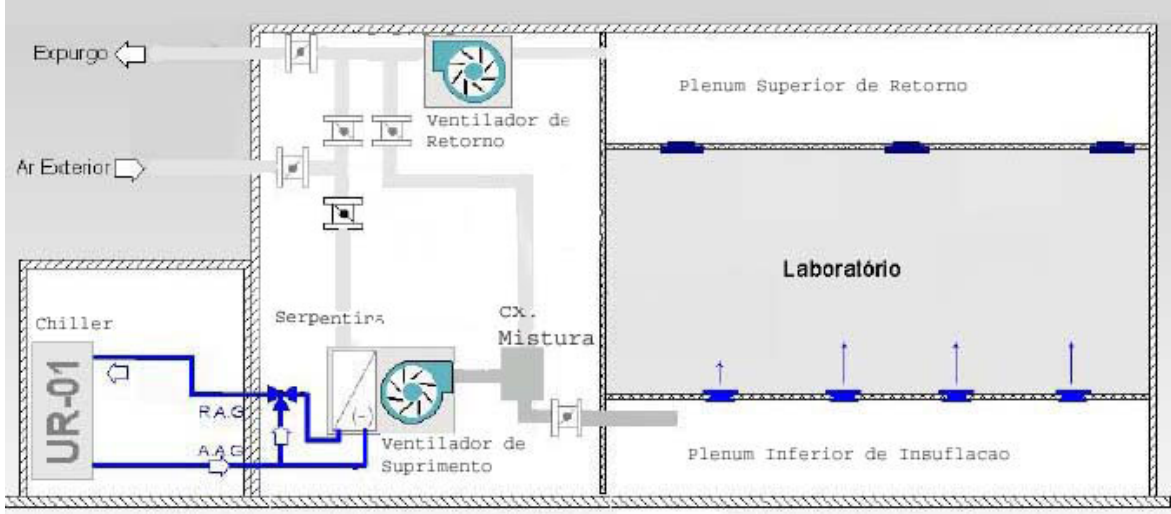

Figura 12 - Corte esquemático do sistema de condicionamento de ar com circuito com desvio de ar de retorno.

Os modelos computacionais desenvolvidos com o duto de desvio de ar de retorno tiveram como referência os dados de controle de temperatura e umidade dos circuitos de ar e água utilizados no laboratório, uma vez que este possui a configuração no circuito de ar similar à descrita. Foram especificados como segue:
a) Temperatura do ar insuflação $=19^{\circ} \mathrm{C}$;
b) Taxa de umidade do ar de insuflação $=10,5 \mathrm{~g} / \mathrm{kg}_{\text {ar seco; }}$;
c) Temperatura da água na serpentina $=8^{\circ} \mathrm{C}$;
d) Temperatura do ar na saída da serpentina $=13^{\circ} \mathrm{C}$.

\subsubsection{Circuito de ar sem duto de desvio de ar de retorno}

Segundo Bauman (2003), para reduzir o consumo de energia do sistema, a temperatura de saída do ar na serpentina pode ser elevada desde que as condições de umidade do ar de entrada sejam baixas. 
Surge então a possibilidade de não utilização do desvio do ar de retorno para se atingir a temperatura de insuflação desejada. Ou seja, controlando-se a saída do ar na serpentina à temperatura e à umidade compatíveis com as condições desejadas no ar de insuflação, pode-se eliminar o duto de desvio de corrente do ar de retorno.

O circuito de ar para simulação dos modelos sem desvio foi modelado da seguinte forma, e pode ser visualizado nos esquemas das figuras 13 e 14:

a) $\mathrm{O}$ ventilador de retorno retira o ar do plenum superior e o insufla no sistema do ar externo. $\mathrm{O}$ ar de retorno é dividido em duas frações: a ser expurgada, e a ser novamente condicionada.

b) No sistema do ar externo ocorrem as operações de expurgo de fração do ar de retorno, tomada de ar externo, e mistura deste último com fração do ar de retorno. Essa mistura de ar é encaminhada para a serpentina de resfriamento, onde ocorre seu condicionamento.

c) $\mathrm{O}$ ar condicionado é então conduzido ao plenum inferior por meio do ventilador de insuflação e os difusores instalados no piso elevado se encarregam da distribuição do ar no ambiente, reiniciando-se o ciclo do ar.

A figura 13 indica esquematicamente a distribuição de ar acima descrita, e a figura 14 indica um corte esquemático do sistema.

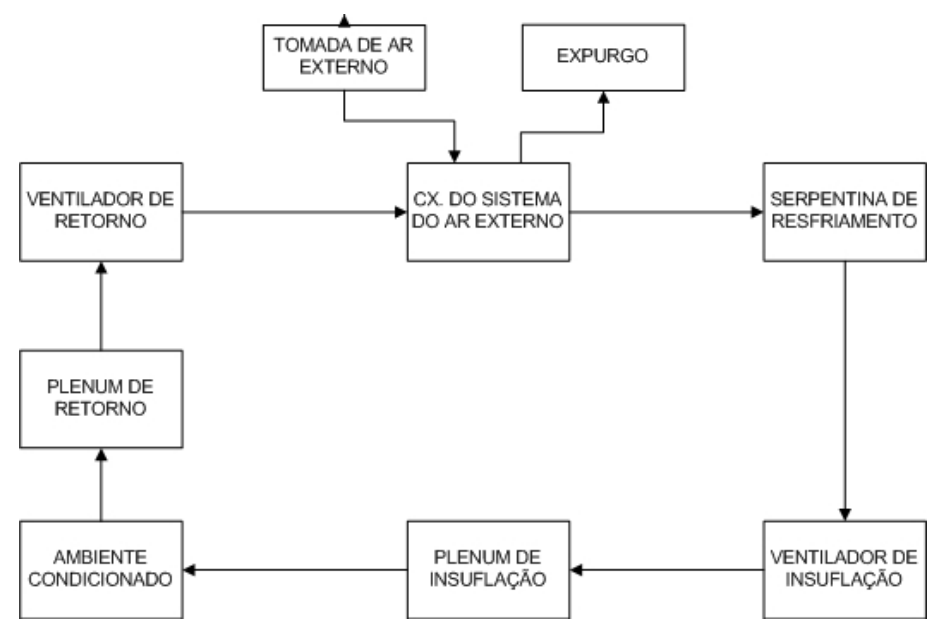

Figura 13 - Circuito sem desvio de ar de retorno. 


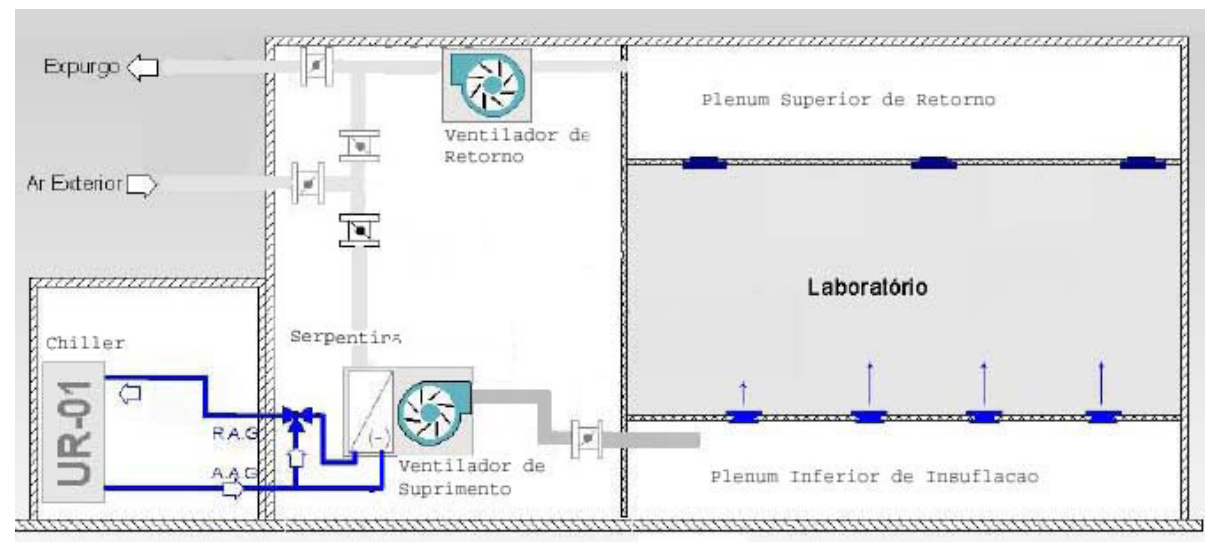

Figura 14 - Corte esquemático do sistema de condicionamento de ar com circuito sem desvio de ar de retorno.

Neste circuito de ar foi utilizado como referência, para a definição da temperatura e umidade ideal do ar na saída da serpentina, o diagrama psicrométrico para cidade de São Paulo. Sendo a temperatura do ar a $24^{\circ} \mathrm{C}$ e umidade relativa de $50 \%$ valores que proporcionam o conforto térmico na zona de ocupação, o diagrama psicrométrico foi utilizado para encontrar os valores de umidade do ar de insuflação, configurado para $19^{\circ} \mathrm{C}$. $\mathrm{O}$ valor de umidade relativa encontrado foi igual a aproximadamente $65 \%$. Considerando uma diferença de temperatura na saída da serpentina de $1^{\circ} \mathrm{C}$ a $2^{\circ} \mathrm{C}$ abaixo da temperatura de insuflação, devido às trocas térmicas ocorridas nos dutos, os seguintes dados de controle de temperatura e umidade dos circuitos de ar e água foram especificados:
a) Temperatura do ar insuflação $=19^{\circ} \mathrm{C}$
b) Taxa de umidade do ar de insuflação $=10,5 \mathrm{~g} / \mathrm{kg}_{\text {ar seco }}$
c) Temperatura da água na serpentina $=11^{\circ} \mathrm{C}$
d) Temperatura do ar na saída da serpentina $=17^{\circ} \mathrm{C}$

\subsubsection{Controle da tomada do ar externo}

Para alcançar a condição de maior tomada de ar exterior, dependendo das condições climáticas, no intuito de atingir a condição de free-cooling (o não resfriamento do ar insuflado) é necessário o controle ótimo da tomada de ar externo. Com esse objetivo, os ciclos economizadores foram utilizados atuando de duas maneiras:

a) Controle das temperaturas limites para tomada do ar exterior;

b) Controle para reutilização do ar de retorno. 
Os dados de controle de temperatura e umidade do ar para as operações dos ciclos economizadores foram definidos considerando, principalmente, o circuito de ar utilizado, visto que este define a temperatura de saída do ar na serpentina de resfriamento.

\subsubsection{Controle das temperaturas limites para tomada do ar exterior}

A definição das temperaturas máximas que permitem o acionamento dos ciclos economizadores foi limitada pela temperatura do ar na saída da serpentina. No circuito de ar com desvio do ar de retorno, a temperatura limite especificada foi igual a $13^{\circ} \mathrm{C}$, e no circuito sem desvio igual a $17^{\circ} \mathrm{C}$.

Com o auxílio da carta psicrométrica para a cidade de São Paulo, foram verificadas as umidades relativas do ar exterior quando nas temperaturas de $13^{\circ} \mathrm{C}$ e $17^{\circ} \mathrm{C}$ (temperaturas de acionamento dos ciclos economizadores), considerando que a taxa de umidade contida neste ar $\left(\mathrm{g} / \mathrm{kg}_{\text {ar seco }}\right)$ deveria corresponder à mesma taxa de umidade do ar de insuflação e da zona de ocupação.

Para as condições de conforto no ambiente, estabelecidas como $24^{\circ} \mathrm{C}$ de temperatura de bulbo seco e 50\% de umidade relativa, a taxa de umidade do ar é de 10,5g/ $\mathrm{kg}_{\text {ar seco. }}$ Logo, a umidade relativa que limita a tomada do ar exterior para a temperatura de $13^{\circ} \mathrm{C}$ é de $100 \%$, e para a temperatura de $17^{\circ} \mathrm{C}$ é de $78 \%$, conforme mostra a figura 15 .

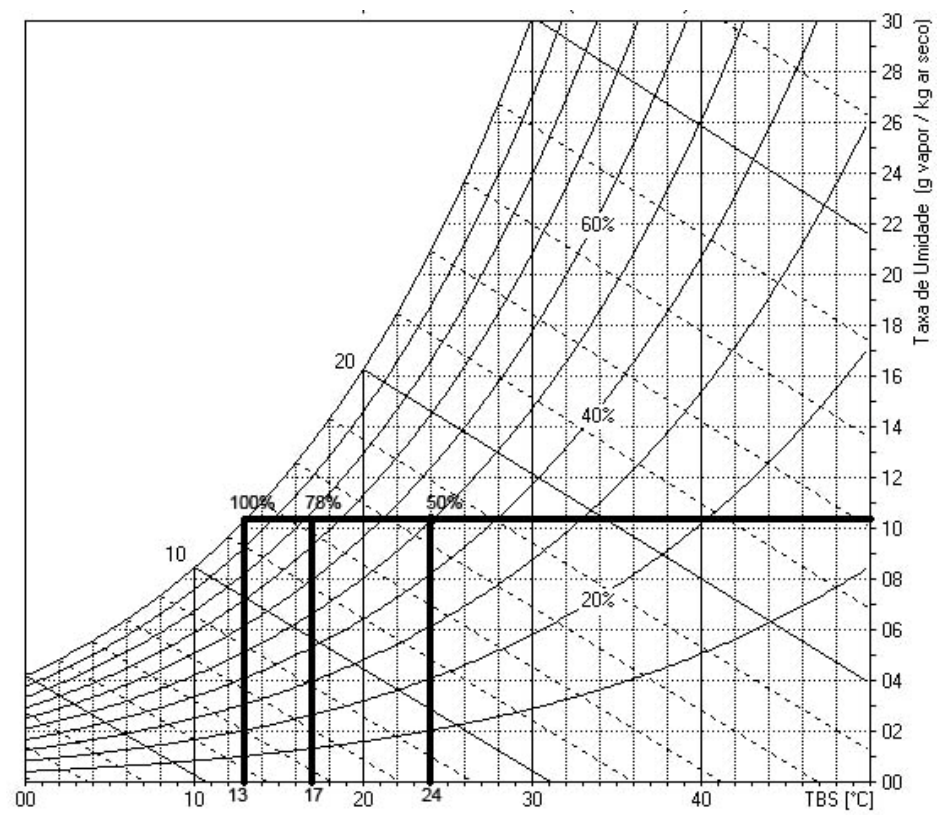

Figura 15 - Carta psicrométrica da cidade de São Paulo. Temperaturas e umidades dos controles dos ciclos economizadores. 


\subsubsection{Controle para reutilização do ar de retorno}

A especificação da temperatura de bulbo seco do ar exterior a $26,5^{\circ} \mathrm{C}$, como limite para o acionamento do ciclo economizador com controle do ar de retorno, foi resultado do estudo dos valores de temperatura de retorno encontrados nas pesquisas de Leite (2003) e Bauman (2003). Estes autores indicam, respectivamente, que quando as temperaturas de insuflação do ar estão entre $19^{\circ} \mathrm{C}$ e $19,5^{\circ} \mathrm{C}$, as temperaturas de retorno mantêm-se entre $24,4^{\circ} \mathrm{C}$ e $26,6^{\circ} \mathrm{C}$, e para temperaturas de insuflação de $18^{\circ} \mathrm{C}$, a temperatura de retorno é de aproximadamente $25,5^{\circ} \mathrm{C}$. Objetivando o melhor aproveitamento deste tipo de controle dos ciclos economizadores, a vazão de ar exterior foi configurada para ser modulada quando sua temperatura estivesse menor ou igual a $26,5^{\circ} \mathrm{C}$.

\subsection{CONFORTO TÉRMICO NO AMBIENTE}

A condição de conforto térmico em ambientes de escritório se baseia principalmente nas variações de: tipo de atividade, vestimenta, temperatura operativa, umidade e velocidade do ar.

As vestimentas são, em geral, relacionadas a hábitos sazonais, ou seja, no inverno as pessoas tendem a vestir roupas com isolamento térmico de aproximadamente 1,0 clo, considerando o clima de São Paulo. E no verão, tendem a vestir roupas mais leves, com isolamento térmico de aproximadamente 0,7 clo.

Considerando a atividade e vestimenta dos usuários, umidade relativa e velocidade do ar adequada para a sensação de conforto térmico no ambiente, a ISO 7730 (1994) sugere uma faixa de temperatura operativa e temperatura operativa ideal, apresentadas na tabela 3.

A figura 16 apresenta uma faixa mais ampla de condições de conforto. Nela estão delimitadas zonas de conforto, para condições de isolamento térmico das roupas igual a 0,5 clo (verão) e 1,0 clo (inverno). As zonas estão definidas em termos de faixas de temperaturas operativas para conforto, em função da combinação de temperatura do ar e temperatura radiante média que promovem condições térmicas aceitáveis, com velocidade do ar inferior a $0,20 \mathrm{~m} / \mathrm{s}$. Teoricamente, quando um ambiente enquadra-se dentro desta faixa, não mais que $10 \%$ das pessoas se sentem insatisfeitas termicamente. 
Tabela 3 - Faixas de temperaturas operativas ótimas, pessoas em atividade leve ( $\leq 1,2$ met), em ambiente com umidade relativa de $50 \%$ e velocidade média do ar $\leq 0,15 \mathrm{~m} / \mathrm{s}$ (ISO 7730,1994 apud Leite, 2003)

\begin{tabular}{|c|c|c|c|c|}
\hline $\begin{array}{l}\text { Estação do } \\
\text { ano }\end{array}$ & Descrição da roupa típica & $\begin{array}{c}\text { Isolamento } \\
\text { térmico da roupa } \\
\text { (clo) }\end{array}$ & $\begin{array}{c}\text { Temperatura } \\
\text { operativa } \\
\text { ótima }\left({ }^{\circ} \mathrm{C}\right)\end{array}$ & $\begin{array}{l}\text { Faixa de temperatura } \\
\text { operativa (para } 10 \% \\
\text { de insatisfeitos) }\left({ }^{\circ} \mathrm{C}\right)\end{array}$ \\
\hline Inverno & $\begin{array}{c}\text { Roupas íntimas } \\
\text { Calça comprida pesada } \\
\text { Camisa de manda comprida } \\
\text { Paleto }\end{array}$ & 1,0 & 22 & 20 a 23,5 \\
\hline Verão & $\begin{array}{c}\text { Roupas íntimas } \\
\text { Calça comprida leve } \\
\text { Camisa de manda curta }\end{array}$ & 0,5 & 24,5 & 23 a 26 \\
\hline
\end{tabular}

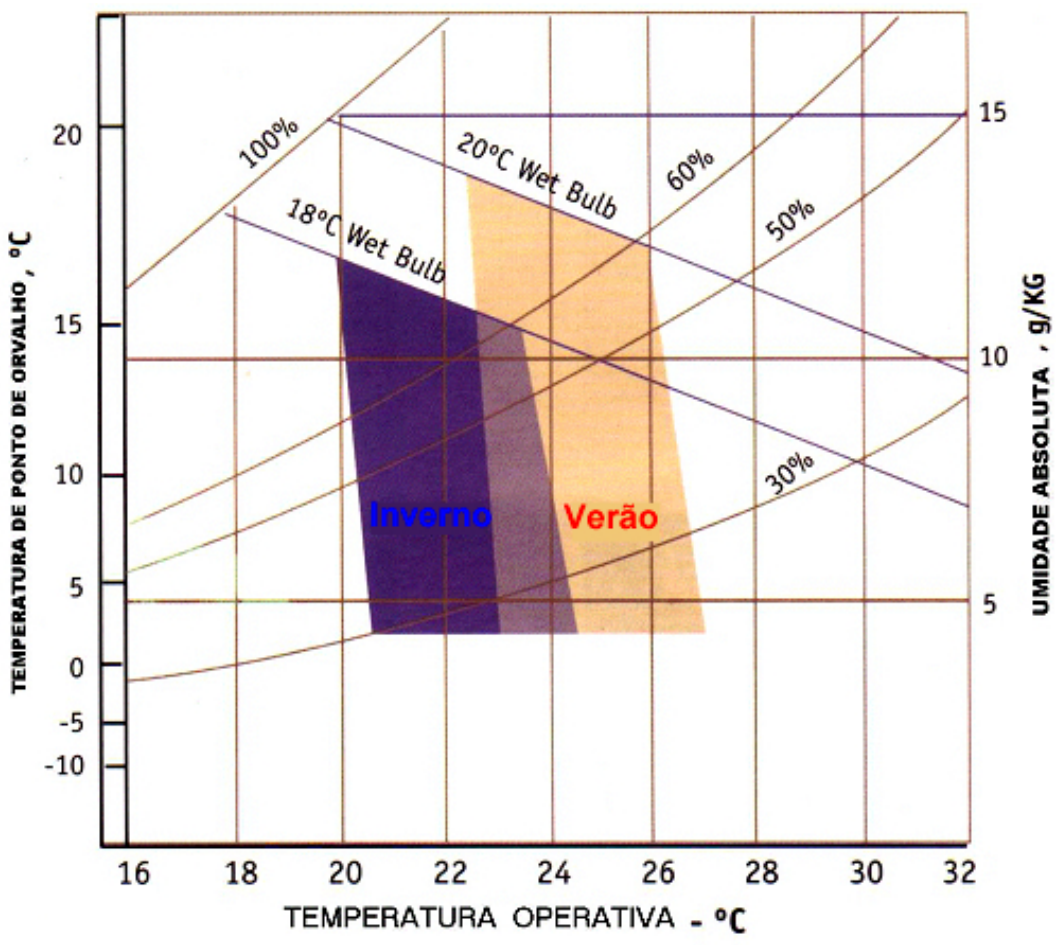

Figura 16 - Zonas de conforto para verão e inverno. Fonte: ASHRAE (2004b).

Em avaliações das condições do conforto térmico pelo método de Fanger (1972), o grau de desconforto é estabelecido como critério e é expresso subjetivamente pelo voto médio estimado (PMV - Predicted Mean Vote), de acordo com a escala de sensação térmica da ASHRAE (2004b), apresentada na tabela 4. 
Tabela 4 - Escala de Sensação Térmica (ASHRAE, 2004b).

\begin{aligned} & \hline+3 MUITO QUENTE \\ &+2 QUENTE \\ &+1 LIGEIRAMENTE QUENTE \\ & 0 NEUTRO \\ &-1 LIGEIRAMENTE FRIO \\ &-2 FRIO \\ &-3 MUITO FRIO \\ & \hline\end{aligned}

O voto médio estimado (PMV) é calculado segundo a seguinte equação:

$$
\mathrm{PMV}=\left[0,303 \mathrm{e}^{-0,036 \mathrm{M}}+0,028\right] \mathrm{L}
$$

Onde M é o metabolismo de uma pessoa em atividade normal de escritórios, e L é a carga térmica definida como a "diferença entre a produção interna de calor e a perda de calor para o ambiente real, para uma pessoa hipoteticamente mantida sob a condição de temperatura média da pele e produção de suor com valores compatíveis para conforto" (Fanger, 1972 apud Leite, 2003), e é representada matematicamente pela seguinte equação:

$\mathrm{L}=\mathrm{M}-\left(\mathrm{R}+\mathrm{C}+\mathrm{E}_{\mathrm{p}}+\mathrm{E}_{\mathrm{r}}+\mathrm{C}_{\mathrm{r}}\right)$

Onde:

$\mathrm{M}=$ metabolismo $\left(\mathrm{W} / \mathrm{m}^{2}\right)$

$\mathrm{W}=$ trabalho externo $\left(\mathrm{W} / \mathrm{m}^{2}\right)$

$\mathrm{R}=$ calor transferido pela pele por radiação $\left(\mathrm{W} / \mathrm{m}^{2}\right)$

$\mathrm{C}=$ calor transferido pela pele por convecção $\left(\mathrm{W} / \mathrm{m}^{2}\right)$

$\mathrm{E}_{\mathrm{p}}=$ calor transferido pela pele por difusão e transpiração $\left(\mathrm{W} / \mathrm{m}^{2}\right)$

$E_{\mathrm{r}}=$ calor evaporativo transferido pela respiração $\left(\mathrm{W} / \mathrm{m}^{2}\right)$

$\mathrm{C}_{\mathrm{r}}=$ calor convectivo transferido pela respiração $\left(\mathrm{W} / \mathrm{m}^{2}\right)$

A ISO 7730 (1994) recomenda para ambientes termicamente aceitáveis os que possuam avaliação de PMV entre +0,5 e -0,5. Fanger (1972) enfatiza que o uso do PMV para avaliação do conforto térmico deve se restringir à faixa $-2 \leq \mathrm{PMV} \leq+2$ e os principais parâmetros estejam dentro dos seguintes intervalos:

a) Metabolismo $=46$ a $232 \mathrm{~W} / \mathrm{m}^{2}(0,8$ a 4 met $)$ 
b) Índice de isolamento da roupa $=0$ a $0,310 \mathrm{~m}^{2} \circ / \mathrm{W}(0$ a 2 clo $)$

c) Temperatura do ar $=10$ a $30^{\circ} \mathrm{C}$

d) Temperatura radiante média $=10$ a $40^{\circ} \mathrm{C}$

e) Velocidade média do ar $=0$ a $1 \mathrm{~m} / \mathrm{s}$

f) Pressão parcial do vapor d' água no ambiente $=0$ a $2700(\mathrm{~Pa})$

g) Umidade relativa $=30$ a $70 \%$

Visto que os modelos simulados tiveram seus parâmetros principais estabelecidos dentro dos intervalos supracitados, a avaliação do conforto térmico do ambiente através da escala de sensação térmica é aplicável.

\subsubsection{Controle do conforto térmico}

O sistema de controle nos casos simulados foi configurado para manter o ambiente dentro da zona de conforto para verão e inverno da ASHRAE (2004b) (figura 16), mantendo a sensação térmica o mais agradável possível.

Para uma altura de $0,60 \mathrm{~m}$, foram especificadas as temperaturas de bulbo seco mínima e máxima, respectivamente, em $23^{\circ} \mathrm{C}$ e $25^{\circ} \mathrm{C}$. Entretanto, como principal modo de controle, foi estabelecido que o ambiente deveria proporcionar temperaturas operativas e umidades relativas que mantivessem o voto médio estimado (PMV) igual a zero, medido na escala de sensação térmica.

Dessa maneira, em todas as simulações, o ambiente teve suas condições de temperatura e umidade especificadas para serem mantidas dentro da zona de conforto.

\subsection{DEFINIÇÃO DOS CASOS PARA AS SIMULAÇÕES}

De posse dos dados das análises supracitadas, foram então definidos os casos para as simulações. Foram considerados: os circuitos de ar com ou sem desvio de ar de retorno; as temperaturas do ar na saída da serpentina; as operações dos ciclos economizadores.

\section{Caso 1}

a) Possui desvio do ar de retorno, sendo a temperatura de saída do ar na serpentina igual a $13^{\circ} \mathrm{C}$, e a temperatura da água na serpentina igual a $8^{\circ} \mathrm{C}$.

b) Não opera com ciclos economizadores. 
c) A vazão de ar exterior é fixa apenas para atender a taxa mínima de renovação, fixa em $27 \mathrm{~m}^{3} / \mathrm{h}$ por pessoa, ficando constante em $108 \mathrm{~m}^{3} / \mathrm{h}$.

\section{Caso 2}

a) Possui desvio do ar de retorno.

b) Opera com ciclo economizador controlado pela temperatura do bulbo seco do ar exterior. O ciclo economizador é acionado quando a temperatura do ar exterior estiver menor ou igual a $13^{\circ} \mathrm{C}$.

c) A vazão mínima de ar exterior é de $27 \mathrm{~m}^{3} / \mathrm{h}$ por pessoa, podendo variar em função do ciclo economizador.

\section{Caso 3}

a) Possui desvio do ar de retorno.

b) Opera com ciclos economizadores controlados pela temperatura do bulbo seco do ar exterior e pela temperatura do ar de retorno. Os ciclos economizadores são acionados quando a temperatura do ar exterior estiver menor ou igual a $26^{\circ} \mathrm{C}$, e/ou quando a temperatura do ar de retorno estiver mais alta que a temperatura do ar exterior.

c) A vazão mínima de ar exterior é de $27 \mathrm{~m}^{3} / \mathrm{h}$ por pessoa, podendo variar em função dos ciclos economizadores.

\section{Caso 4}

a) Não possui desvio do ar de retorno, sendo a temperatura de saída do ar na serpentina igual $17^{\circ} \mathrm{C}$, e a temperatura da água na serpentina igual a $11^{\circ} \mathrm{C}$.

b) Não opera com ciclos economizadores.

c) A vazão de ar exterior é fixa apenas para atender a taxa mínima de renovação do ar, fixa em $27 \mathrm{~m}^{3} / \mathrm{h}$ por pessoa, ficando constante em $108 \mathrm{~m}^{3} / \mathrm{h}$.

\section{Caso 5}

a) Não possui desvio do ar de retorno.

b) Opera com ciclo economizador controlado pela temperatura de bulbo seco do ar exterior. $\mathrm{O}$ ciclo economizador é acionado quando a temperatura do ar exterior estiver menor ou igual a $17^{\circ} \mathrm{C}$.

c) A vazão mínima de ar exterior é de $27 \mathrm{~m}^{3} / \mathrm{h}$ por pessoa, podendo variar em função do ciclo economizador. 


\section{Caso 6}

a) Não possui desvio do ar de retorno.

b) Opera com ciclos economizadores controlados pela temperatura do bulbo seco do ar exterior e pela temperatura do ar de retorno. Os ciclos economizadores são acionados quando a temperatura do ar exterior estiver menor ou igual a $26^{\circ} \mathrm{C}$, e/ou quando a temperatura do ar de retorno estiver mais alta que a temperatura do ar exterior.

c) A vazão mínima de ar exterior é de $27 \mathrm{~m}^{3} / \mathrm{h}$ por pessoa, podendo variar em função dos ciclos economizadores.

Na tabela 5 estão definidas as condições de operação dos seis casos definidos para as simulações.

Tabela 5 - Casos simulados.

\begin{tabular}{|c|c|c|c|c|c|c|c|}
\hline \multirow{2}{*}{\multicolumn{2}{|c|}{ Desvio do ar de retorno }} & Caso 1 & Caso 2 & Caso 3 & Caso 4 & Caso 5 & Caso 6 \\
\hline & & Sim & Sim & Sim & Não & Não & Não \\
\hline \multicolumn{2}{|c|}{ Temp. ar insuflação $\left({ }^{\circ} \mathrm{C}\right)$} & 19 & 19 & 19 & 19 & 19 & 19 \\
\hline \multicolumn{2}{|c|}{$\begin{array}{l}\text { Temp. água na serpentina } \\
\left({ }^{\circ} \mathrm{C}\right)\end{array}$} & 8 & 8 & 8 & 11 & 11 & 11 \\
\hline \multicolumn{2}{|c|}{$\begin{array}{l}\text { Temp. ar na saída da } \\
\text { serpentina }\left({ }^{\circ} \mathrm{C}\right)\end{array}$} & 13 & 13 & 13 & 17 & 17 & 17 \\
\hline \multicolumn{2}{|c|}{$\begin{array}{l}\text { Vazão mínima de ar } \\
\text { externo }\left(\mathrm{m}^{3} / \mathrm{h} \text { por pessoa }\right)\end{array}$} & 27 & 27 & 27 & 27 & 27 & 27 \\
\hline \multirow{2}{*}{ 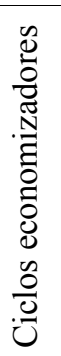 } & $\begin{array}{l}\text { Controle de } \\
\text { temp. do ar } \\
\text { exterior }\end{array}$ & Não & Sim & Sim & Não & Sim & Sim \\
\hline & $\begin{array}{l}\text { Controle de } \\
\text { temp. do ar de } \\
\text { retorno }\end{array}$ & Não & Não & Sim & Não & Não & Sim \\
\hline \multicolumn{2}{|c|}{$\begin{array}{l}\text { Temp. máxima do ar } \\
\text { exterior para acionamento } \\
\text { dos ciclos economizadores }\end{array}$} & - & 13 & 26,5 & - & 17 & 26,5 \\
\hline Cor & de temperatura $\mathrm{e}$ & $\begin{array}{l}\text { dade do c } \\
\text { verão e }\end{array}$ & $\begin{array}{l}\text { ente esta } \\
\text { erno da } A\end{array}$ & $\begin{array}{l}\text { cidos seg } \\
\text { RAE }(20\end{array}$ & o a zona & onforto $t$ & co para \\
\hline
\end{tabular}




\section{RESULTADOS}

\subsection{ANÁLISE DOS DADOS CLIMÁTICOS}

A análise de dados climáticos da cidade de São Paulo foi realizada como estimativa do potencial de aproveitamento do ar externo nos ciclos economizadores, visando a redução do consumo de energia do sistema UFAD. Foram utilizados os dados climáticos do ano metereológico típico (Typical Metereological Year - TMY) da cidade de São Paulo (Aeroporto de Congonhas), considerando os seis casos definidos para estudo.

A possibilidade de utilização dos ciclos economizadores está diretamente relacionada à temperatura e à umidade do ar exterior. Estes são fatores que limitam as operações economizadoras, economizadoras parciais ou free-cooling, visto que altas temperaturas e umidades requerem maior demanda de energia para fazer com que o ar a ser insuflado atinja as condições necessárias ao conforto térmico nos ambientes.

Os dados climáticos foram então analisados para os horários de ocupação do ambiente (das 8 às 19h), verificando-se a ocorrência das seguintes combinações de temperatura e umidade:

a) Para os casos com configuração de circuito de ar com duto de desvio do ar de retorno, definiu-se como parâmetro de análise a temperatura máxima de bulbo seco do ar exterior a $13^{\circ} \mathrm{C}$. Para a avaliação do potencial do ciclo economizador operando no modo free-cooling, acrescentou-se o limite de umidade relativa de $100 \%$, o que não altera a freqüência de ocorrência de temperaturas menores que $13^{\circ} \mathrm{C}$. Os resultados encontram-se na figura 17.

b) Para os casos com configuração de circuito de ar sem duto de desvio do ar de retorno, definiu-se como parâmetro de análise a temperatura máxima de bulbo seco do ar exterior a $17^{\circ} \mathrm{C}$ (figura 18). Para a avaliação do potencial do ciclo economizador operando no modo free-cooling, acrescentou-se o limite de umidade relativa de $78 \%$ (figura 19 ).

c) Para os casos onde o controle do ciclo economizador faz uso da temperatura do ar de retorno, definiu-se como parâmetro de análise a temperatura máxima de bulbo seco do ar exterior a $26,5^{\circ} \mathrm{C}$ (figura 20 ). 


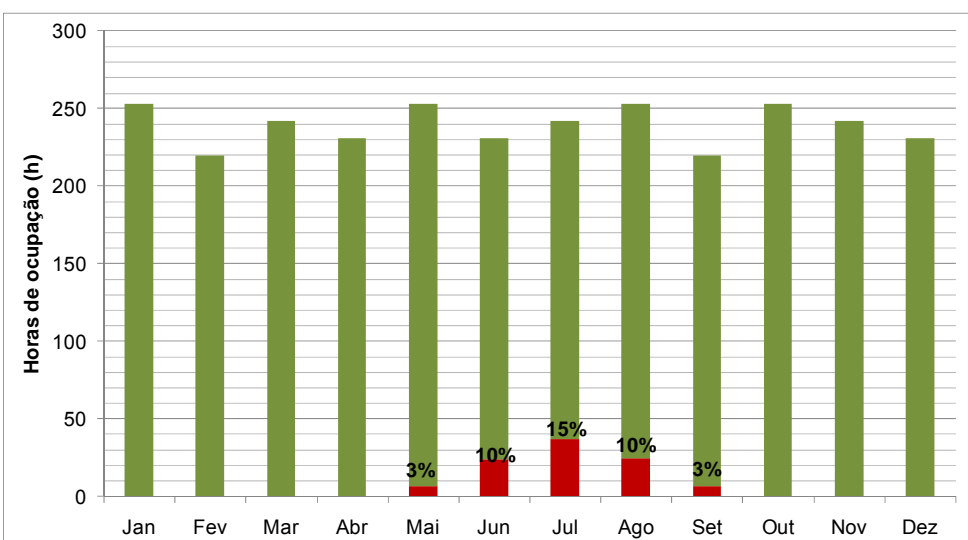

- Horas de ocorrência de temperatura de bulbo seco $\leq 13 \mathrm{C}^{\circ}$ e umidade relativa $\leq 100 \%$ - Horas de ocorrência de condições climáticas diversas

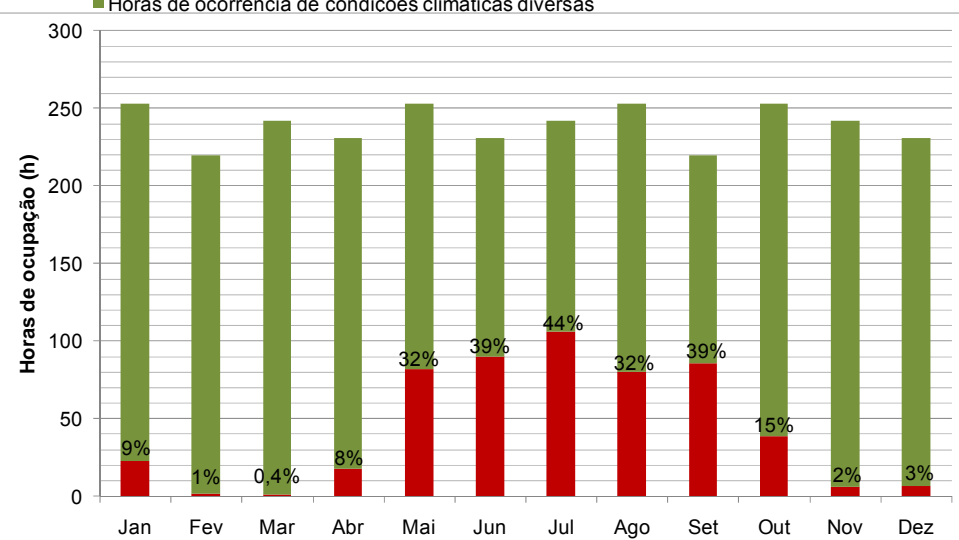

- Horas de ocorrência de temperatura de bulbo seco $\leq 17 \mathrm{C}^{\circ}$

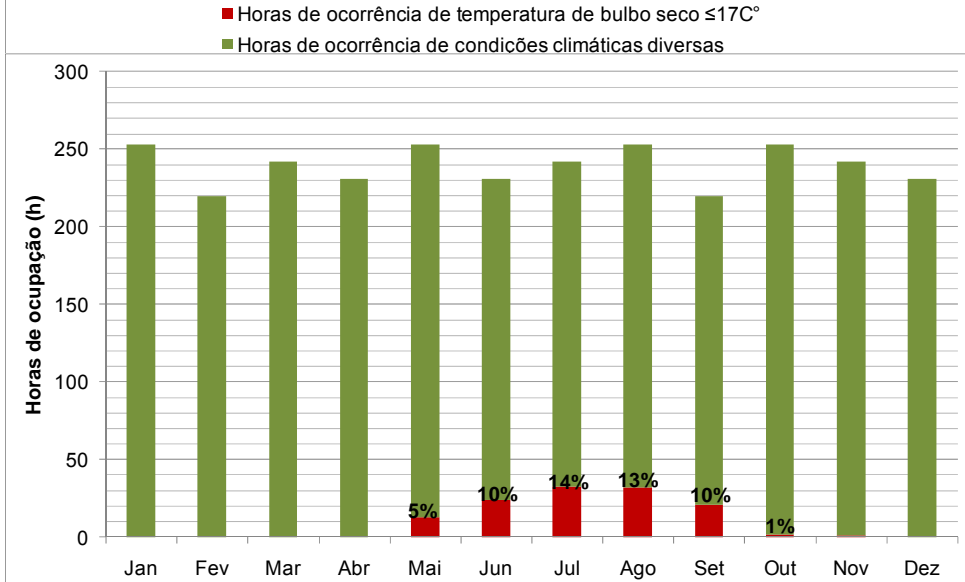

- Horas de ocorrência de temperatura de bulbo seco $\leq 17 \mathrm{C}^{\circ}$ e umidade relativa $\leq 78 \%$ - Horas de ocorrência de condições climáticas diversas

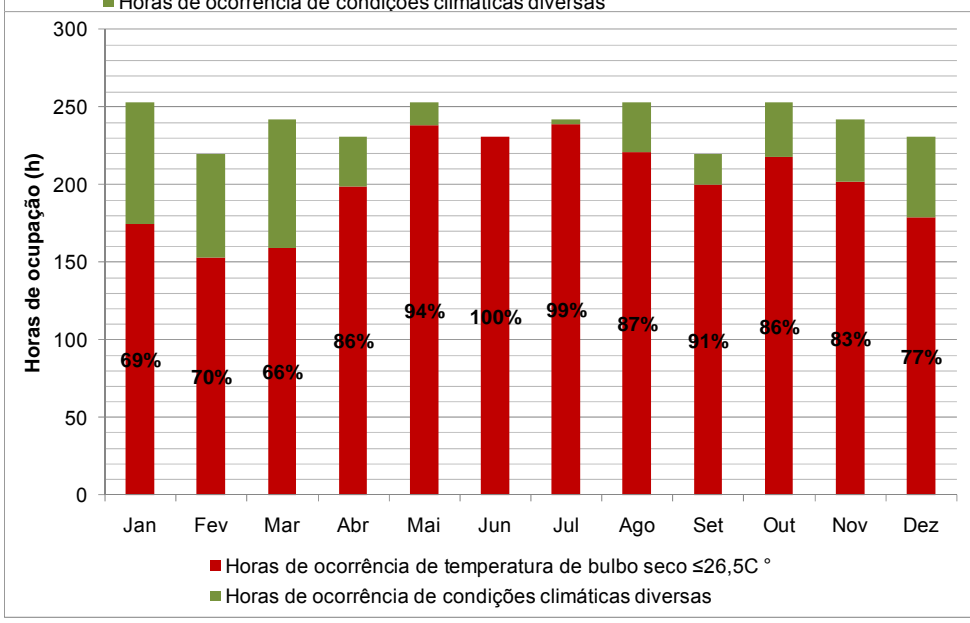

Figura 17 - Frequência de ocorrência de temperatura de bulbo seco $\leq 13^{\circ} \mathrm{C}$ e umidade relativa $\leq 100 \%$.

Figura 18 - Frequência de ocorrência de temperatura de bulbo seco $\leq 17^{\circ} \mathrm{C}$.

Figura 19 - Frequência de ocorrência de temperatura de bulbo seco $\leq 17^{\circ} \mathrm{C}$ e umidade relativa $\leq 78 \%$.

Figura 20 - Frequência de ocorrência de temperatura de bulbo seco $\leq 26,5^{\circ} \mathrm{C}$. 
As temperaturas de bulbo seco menores ou iguais a $13^{\circ} \mathrm{C}$ e umidades relativas menores ou iguais a $100 \%$ ocorrem entre os meses de maio a setembro, em 100 horas, das 2871 horas de funcionamento do sistema de condicionamento de ar. Isto significa que, para a configuração do sistema com circuito de ar com desvio do ar de retorno, os ciclos economizadores, com controle realizado pela temperatura do ar exterior, podem atuar num período correspondente a $3,46 \%$ das horas ocupadas durante um ano.

As temperaturas de bulbo seco do ar exterior menores ou iguais a $17^{\circ} \mathrm{C}$ ocorrem em 540 horas, das 2871 horas de funcionamento do sistema de condicionamento de ar, propiciando o acionamento dos ciclos economizadores durante $18,8 \%$ das horas ocupadas durante um ano. Acrescentando o limite de umidade relativa de $78 \%$, esta ocorrência diminui para 126 horas, o que indica que o acionamento dos ciclos economizadores no modo de operação específico do free-cooling pode ocorrer em 4,38\% das horas ocupadas durante um ano.

As temperaturas de bulbo seco menores ou iguais a $26,5^{\circ} \mathrm{C}$ ocorrem durante todo o ano, em 2414 horas, das 2871 horas de funcionamento do sistema de condicionamento de ar. Isto significa que, com o controle dos ciclos economizadores por meio da temperatura do ar de retorno, estes podem atuar em $84,07 \%$ das horas ocupadas durante um ano.

Nota-se, portanto, que a configuração do circuito de ar e o sistema de controle de acionamento dos ciclos economizadores podem ou não majorar a possibilidade de utilização do ar exterior como proposta para redução do consumo de energia do sistema UFAD.

As médias horárias e desvio padrão das temperaturas e umidades do ar exterior, assim como as máximas e mínimas das temperaturas foram dispostas nos gráficos das figuras 21 a 24. Tais dados foram utilizados para compreender o comportamento dos casos simulados de um modo geral, principalmente no que se refere à tomada de vazão do ar exterior e à carga térmica de refrigeração. 


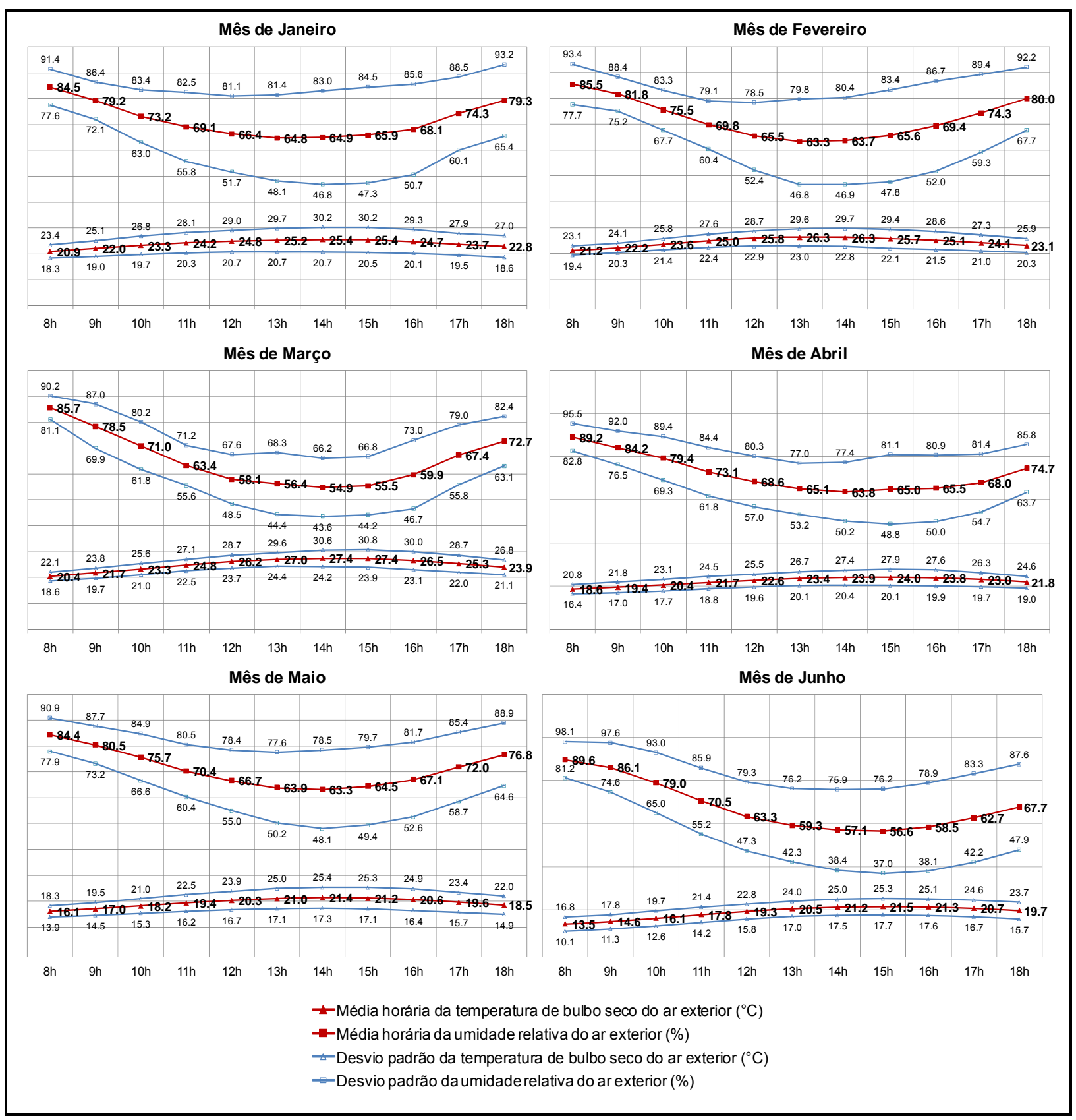

Figura 21 - Médias horárias e desvio padrão das temperaturas $\left({ }^{\circ} \mathrm{C}\right)$ e umidades do ar exterior $(\%)$. Meses de Janeiro a Junho. 


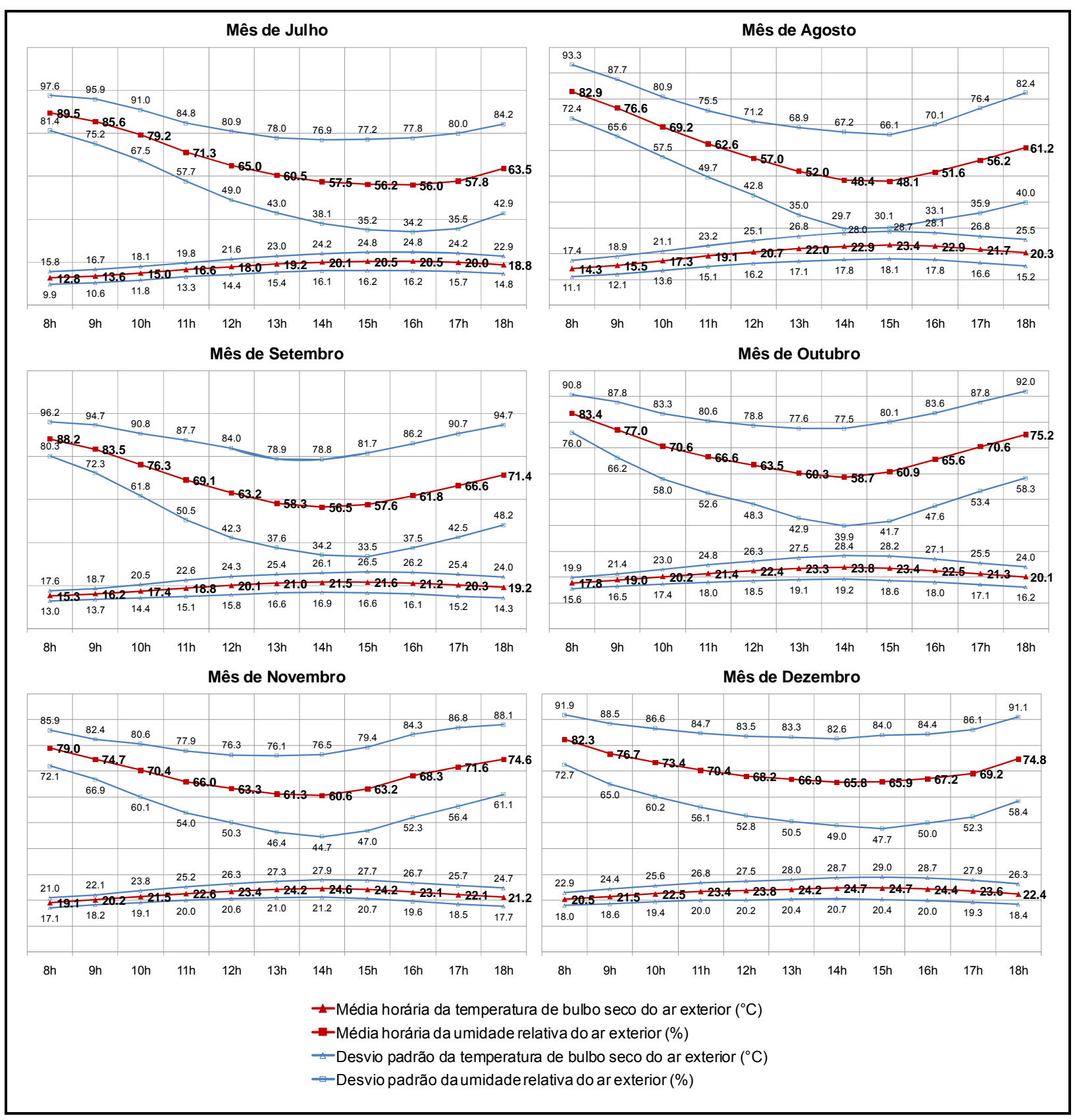

Figura 22 - Médias horárias e desvio padrão das temperaturas $\left({ }^{\circ} \mathrm{C}\right)$ e umidades do ar exterior $(\%)$.Meses de Julho a Dezembro. 


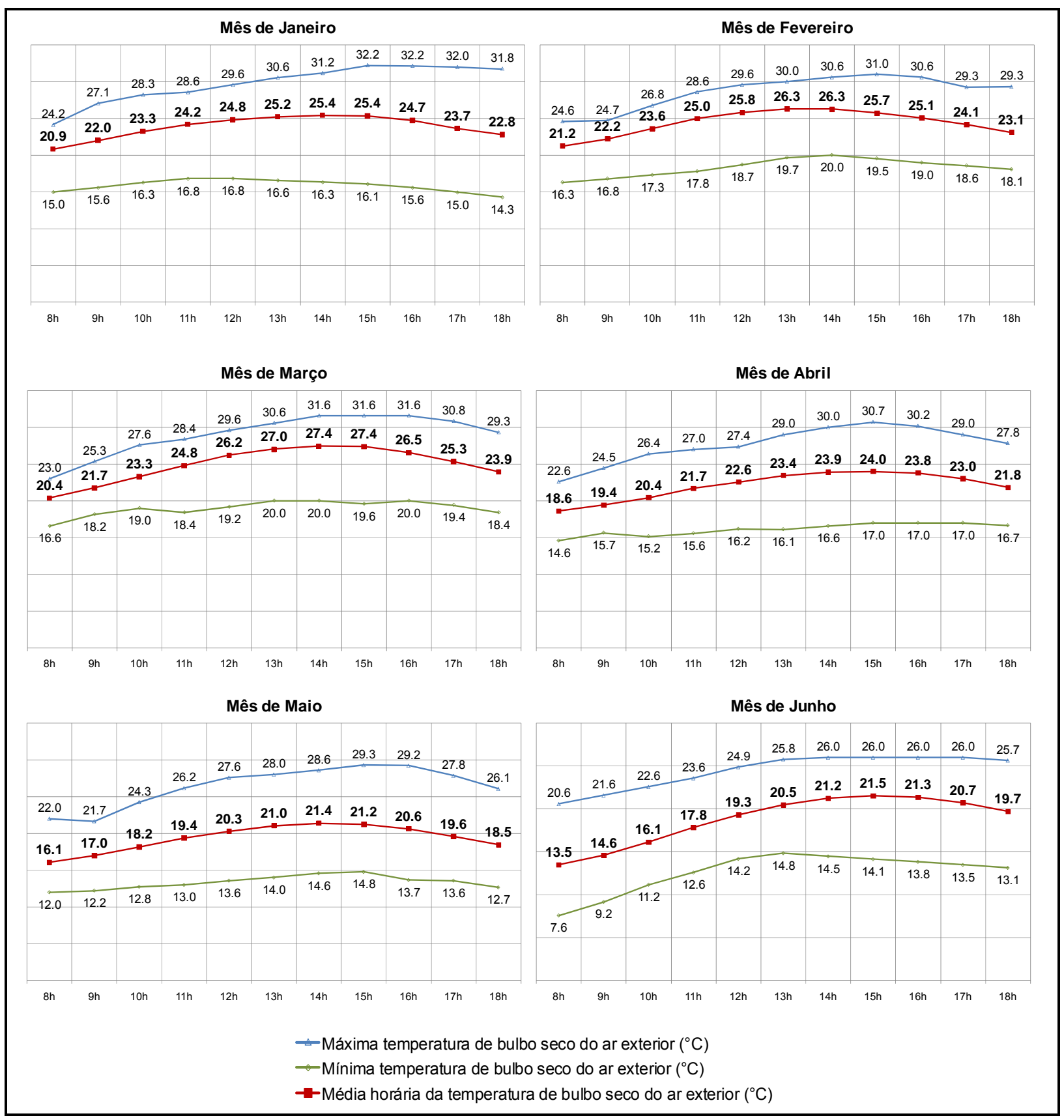

Figura 23 - Médias horárias, máximas e mínimas das temperaturas do ar exterior $\left({ }^{\circ} \mathrm{C}\right)$. Meses de Janeiro a Junho. 


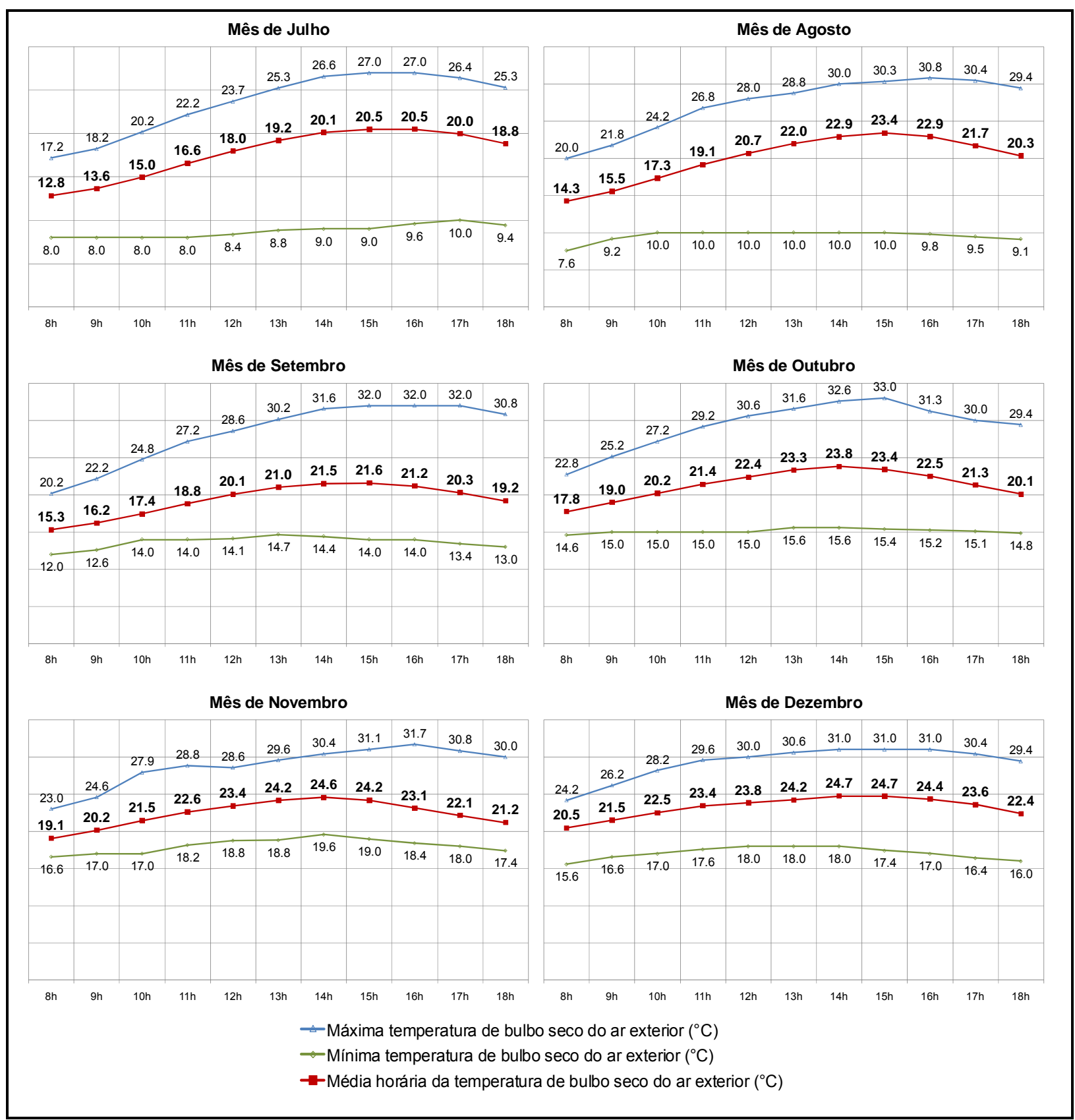

Figura 24 - Médias horárias, máximas e mínimas das temperaturas do ar exterior $\left({ }^{\circ} \mathrm{C}\right)$. Meses de Julho a Dezembro. 


\subsection{VERIFICAÇÃO DO DIMENSIONAMENTO DOS EQUIPAMENTOS}

A seguir serão descritas as verificações dos equipamentos especificados por meio da análise dos resultados das simulações iniciais dos modelos, assunto este discutido anteriormente no item 3.3.

A capacidade nominal da unidade de resfriamento de água foi verificada segundo os cálculos de carga térmica interna do modelo, demonstrados a seguir.

Considerando a equação para cálculo de carga térmica,

$$
Q=V \cdot \rho \cdot c \cdot \Delta t \cdot 10^{-3}
$$

Onde,

$Q=$ carga térmica de resfriamento $(\mathrm{W})$

$V=375,65 \mathrm{~m}^{3} / \mathrm{h}$, resultante da vazão de $3 \mathrm{~L} / \mathrm{s} / \mathrm{m}^{2}\left(10,8 \mathrm{~m}^{3} / \mathrm{h} / \mathrm{m}^{2}\right)$, proposta por Bauman (2003) para zonas internas ocupadas, e da área do modelo igual a 34,782 $\mathrm{m}^{2}$.

$\rho=1,2 \mathrm{~kg} / \mathrm{m}^{3}$, densidade do ar.

$C=1000 \mathrm{~J} / \mathrm{kg} . \mathrm{K}$, calor específico do ar.

$\Delta t=7,5 \mathrm{~K}$, ou $7,5^{\circ} \mathrm{C}$, resultante da diferença entre as temperaturas do ar de retorno e do ar de insuflação $\rightarrow 26,5^{\circ} \mathrm{C}-19^{\circ} \mathrm{C}=7,5^{\circ} \mathrm{C}$.

Tem-se que:

$Q=375,65 \times 1,2 \times 1000 \times 7,5 \times 10^{-3}$

$Q=3380,85 \mathrm{~W}$

Visto que, dos resultados das simulações iniciais, a maior capacidade nominal da unidade de resfriamento foi igual a $3180,72 \mathrm{~W}$, optou-se por estabelecer a capacidade nominal de tal equipamento em $3500 \mathrm{~W}$ (aproximadamente 1TR), disponibilizando aproximadamente $100 \mathrm{~W} / \mathrm{m}^{2}$. Esta capacidade foi suficiente para que, em todos os casos, o sistema de condicionamento de ar fosse capaz de retirar a carga térmica interna.

Para a especificação do dimensionamento da bomba foi utilizada a ASHRAE Standard 90.1 (ASHRAE, 2004d), que estabelece o valor de $349 \mathrm{~kW} / 1000 \mathrm{~L} / \mathrm{s}$ para um sistema de bombeamento eficiente. Verificada a vazão máxima de água calculada pelo programa computacional em $0,000133 \mathrm{~m}^{3} / \mathrm{s}$, definiu-se a vazão de água a ser utilizada em todos os casos em $0,000135 \mathrm{~m}^{3} / \mathrm{s}(486 \mathrm{~L} / \mathrm{h})$, e motor de $47 \mathrm{~W}(0,063 \mathrm{CV})$.

A serpentina de resfriamento teve sua vazão máxima de água variada segundo o circuito de ar definido para o sistema, e acompanhou a vazão de água na unidade de resfriamento e na bomba. Nos modelos com circuito de ar com desvio de corrente de ar de 
retorno, a vazão máxima de água calculada foi igual a $0,000133 \mathrm{~m}^{3} / \mathrm{s}(478,8 \mathrm{~L} / \mathrm{h})$, e nos modelos com circuito de ar sem desvio de retorno, foi igual a $0,000114 \mathrm{~m}^{3} / \mathrm{s}(410,4 \mathrm{~L} / \mathrm{h})$.

Bauman (2003) indica a vazão de $3 \mathrm{~L} / \mathrm{s} / \mathrm{m}^{2}$ como adequada para que o sistema UFAD promova zonas inferior (ocupada), de estratificação e superior bem definidas, sem comprometer o conforto térmico no ambiente e propiciando redução no consumo de energia. Considerando a área do ambiente igual a $34,782 \mathrm{~m}^{2}$, tem-se:

Vazão Ambiente $=3 \mathrm{~L} / \mathrm{s} / \mathrm{m}^{2} \times 34,782 \mathrm{~m}^{2}=104,346 \mathrm{~L} / \mathrm{s}=0,104346 \mathrm{~m}^{3} / \mathrm{s}$

Os ventiladores de insuflação e retorno tiveram suas vazões máximas de ar dimensionadas pelo programa computacional em $0,117392 \mathrm{~m}^{3} / \mathrm{s}\left(422,6 \mathrm{~m}^{3} / \mathrm{h}\right)$, e potência no motor $16,77 \mathrm{~W}(0,0224 \mathrm{CV})$. Este resultado foi constante em todos os modelos simulados, e é compatível com a vazão de ar proposta por Bauman (2003).

\subsection{COMPARAÇÃO COM DADOS DE MEDIÇÕES}

As temperaturas num ambiente, com sistema UFAD instalado, delineiam uma curva característica de distribuição de temperatura, em função da mistura do ar na zona ocupada, da estratificação e concentração de ar aquecido na zona superior.

Para a verificação dos modelos de simulação foram comparadas as curvas de distribuição de temperatura resultantes dos casos simulados com as curvas resultantes de dados medidos no "Laboratório Representativo de Ambiente de Escritórios".

Os dados medidos foram extraídos da pesquisa de Leite (2003), onde, em seus anexos, disponibiliza os valores medidos das variáveis de conforto térmico para diferentes condições de ensaio realizadas.

A condição de ensaio especificada para esta análise foi realizada em função dos parâmetros de funcionamento da mesma e em Leite (2003) é denominada "Condição de Ensaio C5”. Os parâmetros deste ensaio são os que mais se aproximam dos aqui utilizados para as simulações. São eles:

a) Temperatura do ar insuflado $=19^{\circ} \mathrm{C}$

b) Umidade relativa do ar insuflado $=62 \%$

c) Temperatura do ar no ambiente $=24,1^{\circ} \mathrm{C}$

d) Umidade relativa do ar no ambiente $=43 \%$ 
e) Temperatura do ar na saída da serpentina de resfriamento $=13,1^{\circ} \mathrm{C}$

f) Temperatura da água na serpentina $=8^{\circ} \mathrm{C}$

As medições foram realizadas em regime permanente, por cerca de oito horas, e contemplaram 20 pontos distribuídos da seguinte maneira: 12 pontos na zona interna ocupada, 3 pontos nas zonas internas de circulação, 1 ponto na zona perimetral, 4 pontos sobre difusores. As médias das temperaturas medidas por ponto encontram-se na tabela 6 , dispostas respectivamente conforme a distribuição supracitada.

A aquisição dos dados foi feita a cada 0,2 segundos, com médias calculadas e gravadas a cada 10 segundos, em arquivo de planilha eletrônica. Para cada período de 5 minutos, foram determinadas as médias aritméticas das medidas e os desvios padrão (LEITE, 2003).

Tabela 6 - Temperaturas médias em diferentes alturas do ambiente para 20 pontos medidos em ensaio experimental realizado por Leite (2003).

\begin{tabular}{|c|c|c|c|c|c|c|c|}
\hline \multicolumn{8}{|c|}{ Temperatura $\left({ }^{\circ} \mathrm{C}\right)$} \\
\hline & Altura & $0,10(\mathrm{~m})$ & $0,60(\mathrm{~m})$ & $1,10(\mathrm{~m})$ & $1,70(\mathrm{~m})$ & $2,00(\mathrm{~m})$ & $2,35(\mathrm{~m})$ \\
\hline Ponto 1 & & 23,5 & 23,4 & 23,9 & 25,3 & 26,1 & 26,6 \\
\hline Ponto 2 & & 23,3 & 23,0 & 22,9 & 25,4 & 26,2 & 26,6 \\
\hline Ponto 3 & & 23,4 & 22,9 & 23,0 & 25,6 & 26,3 & 26,5 \\
\hline Ponto 4 & & 23,2 & 22,9 & 25,4 & 25,5 & 26,0 & 26,3 \\
\hline Ponto 5 & & 23,2 & 22,9 & 22,6 & 25,4 & 26,1 & 26,5 \\
\hline Ponto 6 & & 23,4 & 23,4 & 23,9 & 25,1 & 26 & 26,4 \\
\hline Ponto 7 & & 24,4 & 24,5 & 25,0 & 25,4 & 25,8 & 26,8 \\
\hline Ponto 8 & & 24,1 & 24,2 & 24,8 & 25,4 & 25,9 & 26,6 \\
\hline Ponto 9 & & 24,0 & 24,3 & 24,8 & 25,7 & 26,2 & 26,9 \\
\hline Ponto 10 & & 24,0 & 24,2 & 25,2 & 25,7 & 26,2 & 26,8 \\
\hline Ponto 11 & & 23,4 & 23,9 & 24,2 & 25,2 & 25,5 & 26,0 \\
\hline Ponto 12 & & 24,1 & 24,4 & 25,2 & 25,6 & 26,4 & 26,6 \\
\hline Ponto 13 & & 22,6 & 22,6 & 23,9 & 25,4 & 26,0 & 26,6 \\
\hline Ponto 14 & & 22,8 & 23,0 & 23,9 & 25,4 & 25,9 & 26,5 \\
\hline Ponto 15 & & 23,6 & 23,8 & 23,8 & 24,8 & 26,0 & 26,4 \\
\hline Ponto 16 & & 22,5 & 23,0 & 24,1 & 25,9 & 26,4 & 26,6 \\
\hline Ponto 17 & & 21,1 & 22,3 & 23,3 & 25,5 & 26,1 & 26,6 \\
\hline Ponto 18 & & 22,6 & 24,0 & 24,8 & 25,6 & 26,3 & 26,5 \\
\hline Ponto 19 & & 21,4 & 22,1 & 23,8 & 25,7 & 26,3 & 26,5 \\
\hline Ponto 20 & & 24,1 & 24,1 & 25,0 & 26,1 & 26,5 & 26,7 \\
\hline
\end{tabular}


As medições de temperatura do ar foram realizadas quando o sistema operava com carga térmica interna de 4209,1 W, ou seja, aproximadamente $2723,2 \mathrm{~W}$ mais alta que a definida para as simulações desta pesquisa. Isto porque nos ensaios de Leite (2003) a carga térmica representativa da incidência de radiação solar foi considerada. Entretanto, isso não invalida as comparações, pois, visto que o sistema de controle estava configurado com os parâmetros similares aos dos casos simulados, a vazão do ar insuflado foi proporcional à carga térmica a ser retirada no ambiente. Além disso, para traçar o perfil de temperaturas do ambiente, os pontos de medição correspondentes às zonas perimetrais foram desconsiderados, assim como os pontos medidos sobre os difusores, que correspondem às zonas limpas (clear zones)

De posse de tais dados, a curva representativa da distribuição de temperatura no ambiente foi traçada (Figura 25) a partir das médias calculadas para cada altura, dos pontos 1 a 15, medidos nas zonas internas ocupada e de circulação (tabela 7).

Tabela 7 - Médias das temperaturas obtidas em ensaio experimental (LEITE, 2003), representando as temperaturas em diferentes alturas do ambiente.

\begin{tabular}{rrrrrr}
\hline \multicolumn{7}{c}{ Temperaturas $\left({ }^{\circ} \mathrm{C}\right)$} \\
\hline $0.1(\mathrm{~m})$ & $0.6(\mathrm{~m})$ & $1.1(\mathrm{~m})$ & $1.7(\mathrm{~m})$ & $2(\mathrm{~m})$ & $2.35(\mathrm{~m})$ \\
23.53 & 23.56 & 24.17 & 25.39 & 26.04 & 26.54 \\
\hline
\end{tabular}

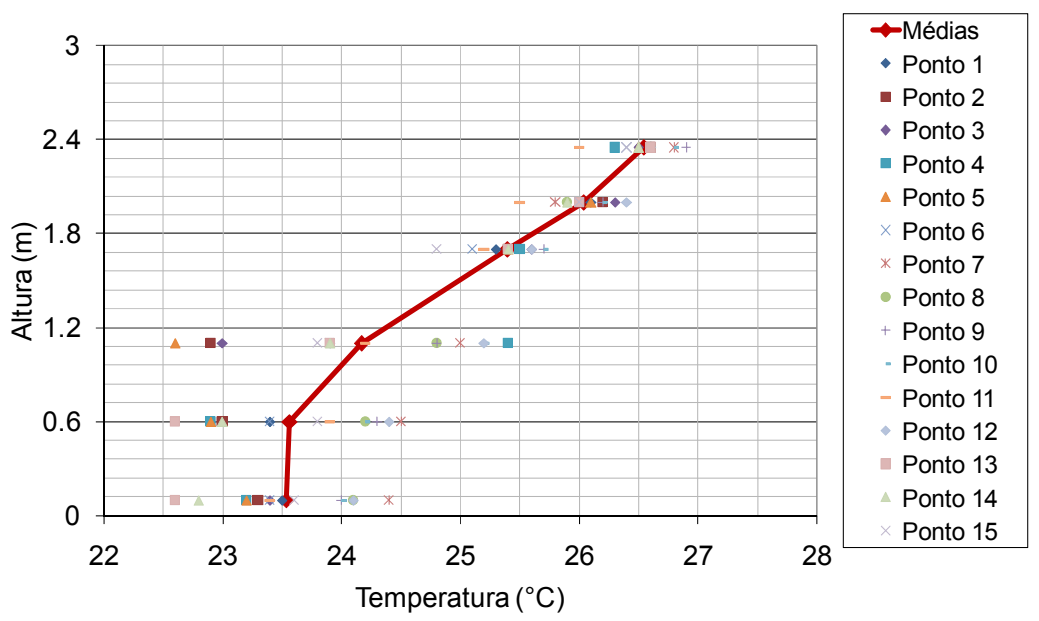

Figura 25 - Curva representativa da distribuição de temperatura no ambiente, resultante de ensaios experimentais realizados por Leite (2003). 
Para delinear as curvas de distribuição de temperatura resultantes dos seis casos simulados foram calculadas as médias anuais de temperatura do ar para cada uma das seguintes zonas: zona ocupada, zona superior, e plenum de retorno. Tais médias foram calculadas utilizando resultados dos relatórios horários das temperaturas citadas, e alturas de transição entre as zonas, fornecidos por simulação computacional, para o período de ocupação do ambiente durante um ano típico. Os resultados podem ser visualizados na tabela 8 .

A altura de transição entre as zonas foi utilizada para encontrar a posição de simulação da temperatura da zona superior. Isso se fez necessário visto que as alturas das zonas ocupada e superior são resultado das vazões e temperatura do ar insuflado, e das cargas térmicas na zona ocupada, fazendo com a temperatura da zona superior não seja constante.

As curvas de temperatura do ar dos seis casos simulados foram definidas por três pontos nas seguintes alturas: 0,60m (posição fixa do termostato da zona ocupada); aproximadamente $2,10 \mathrm{~m}$ (posição do ponto médio da zona superior); $2,95 \mathrm{~m}$ (posição fixa do ponto médio da altura do plenum de retorno).

Tabela 8 - Médias das temperaturas resultantes dos casos simulados, representando as temperaturas em diferentes alturas do ambiente.

\begin{tabular}{crrrrr}
\hline \multicolumn{2}{c}{ Caso 1 } & \multicolumn{3}{c}{ Caso 2 } & \multicolumn{3}{c}{ Caso 3 } \\
\hline $\mathrm{T}\left({ }^{\circ} \mathrm{C}\right)$ & Altura $(\mathrm{m})$ & $\mathrm{T}\left({ }^{\circ} \mathrm{C}\right)$ & Altura $(\mathrm{m})$ & $\mathrm{T}\left({ }^{\circ} \mathrm{C}\right)$ & Altura $(\mathrm{m})$ \\
23,5 & 0,60 & 23,5 & 0,60 & 23,1 & 0,60 \\
26,0 & 2,09 & 26,0 & 2,08 & 26,1 & 1,88 \\
25,8 & 2,95 & 25,8 & 2,95 & 25,9 & 2,95 \\
\hline Caso 4 & \multicolumn{7}{c}{ Caso 5 } & & Caso 6 \\
\hline $\mathrm{T}\left({ }^{\circ} \mathrm{C}\right)$ & Altura $(\mathrm{m})$ & $\mathrm{T}\left({ }^{\circ} \mathrm{C}\right)$ & Altura $(\mathrm{m})$ & $\mathrm{T}\left({ }^{\circ} \mathrm{C}\right)$ & Altura $(\mathrm{m})$ \\
23,4 & 0,60 & 23,4 & 0,60 & 23,4 & 0,60 \\
25,9 & 2,11 & 25,9 & 2,11 & 25,9 & 2,11 \\
25,7 & 2,95 & 25,7 & 2,95 & 25,7 & 2,95 \\
\hline
\end{tabular}

A figura 26 indica o comportamento das seis curvas definidas por simulações, e a curva definida pelos dados medidos de Leite (2003). 


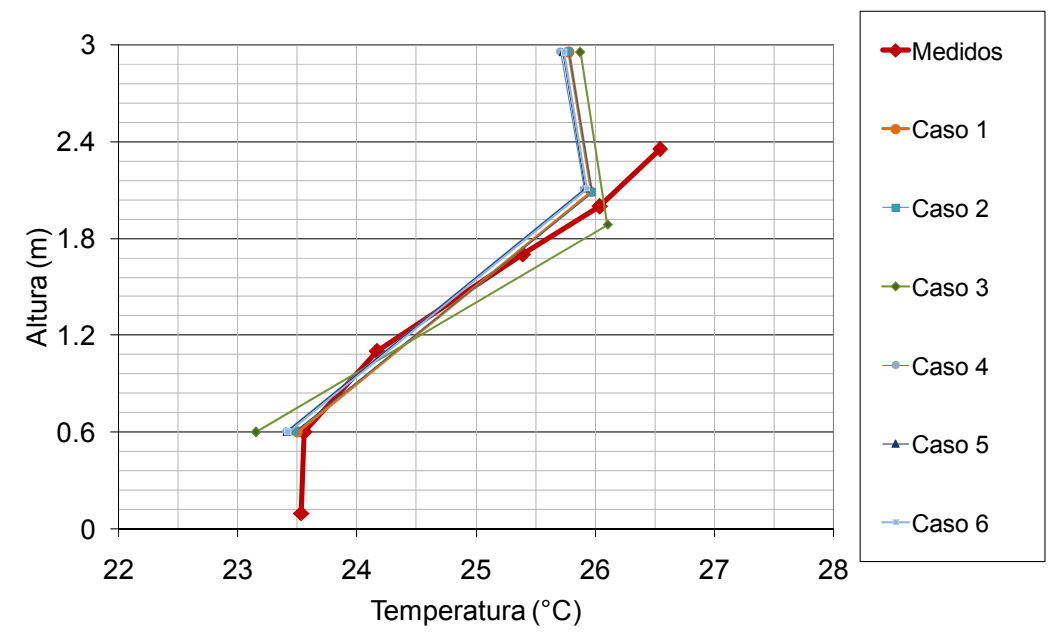

Figura 26 - Curvas representativas das distribuições de temperatura no ambiente resultantes dos seis casos simulados (Caso 1 a 6), e curva resultante dos dados medidos em ensaio experimental (Medidos).

Observa-se que os seis casos simulados apresentam desempenho semelhante, segundo o modelo de ar do EnergyPlus, e que as curvas de temperatura estimadas por simulação possuem um comportamento muito próximo à curva obtida por Leite (2003) em ensaio de laboratório.

\subsection{ANÁLISE DAS CONDIÇÕES DE CONFORTO TÉRMICO}

Realizadas as simulações, fez-se necessário a análise dos modelos quanto à manutenção do conforto térmico, verificando se as temperaturas do ar no ambiente, e o seu comportamento em relação às zonas de conforto para verão e inverno propostas pela ASHRAE (2004b), mostrada na figura 16 do capítulo 3, item 3.4.

A figura 27 indica as médias mensais das: temperatura de bulbo seco do ar insuflado, temperatura na zona ocupada, temperatura na zona superior, altura de transição entre as zonas ocupada e superior, umidade relativa na zona ocupada, e vazão do ar no ambiente. Tais médias foram calculadas utilizando resultados dos relatórios horários das simulações computacionais, para o período de ocupação do ambiente, durante um ano típico. 


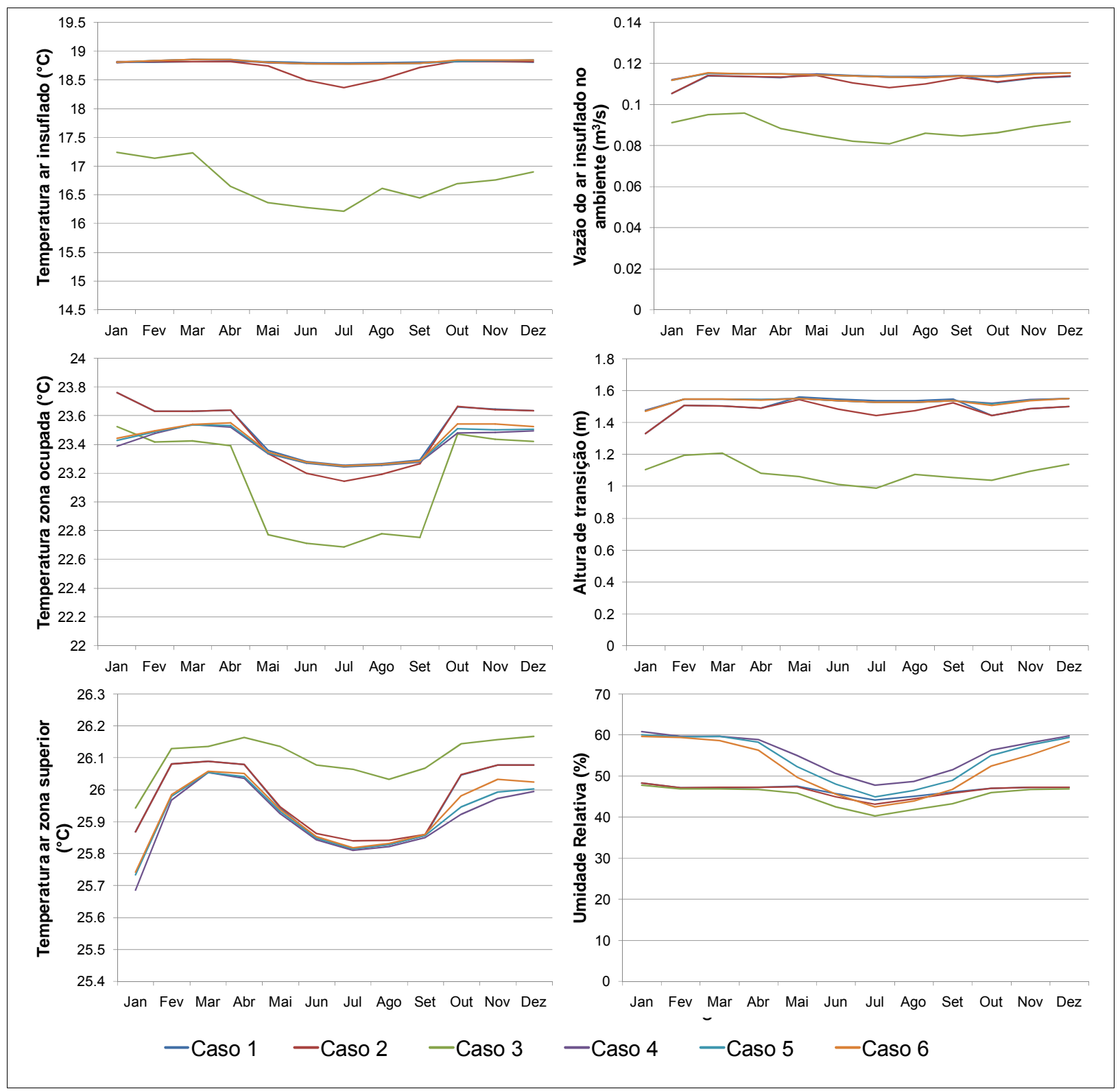

Figura 27 - Casos simulados. Gráficos das médias mensais de: temperatura de bulbo seco do ar insuflado, temperatura na zona ocupada, temperatura na zona superior, vazão do ar no ambiente, altura de transição entre as zonas ocupada e superior, e umidade relativa na zona ocupada.

Dos resultados dos gráficos tem-se que, para os seis casos simulados:

a) A temperatura do ar insuflado foi controlada dentro da faixa de $16^{\circ} \mathrm{C}$ e $20^{\circ} \mathrm{C}$, entendida como a faixa ideal de temperatura do ar insuflado, prevalecendo, na maioria dos casos, a temperatura aproximada de $19^{\circ} \mathrm{C}$, estabelecida como temperatura de projeto.

b) A temperatura na zona ocupada distribui-se entre $22^{\circ} \mathrm{C}$ e $24^{\circ} \mathrm{C}$;

c) A umidade relativa do ambiente manteve-se entre $40 \%$ e $61 \%$;

d) A temperatura na zona superior manteve-se entre $25,3^{\circ} \mathrm{C}$ e $26,2^{\circ}$; 
e) A transição entre a zona ocupada e a zona superior ocorreu na faixa de altura entre $1 \mathrm{~m} \mathrm{e} 1,6 \mathrm{~m}$.

Considerando a temperatura do ar da zona ocupada igual à temperatura operativa ${ }^{2}$ (média aritmética da temperatura do ambiente e da temperatura radiante média), as condições de conforto térmico dos casos simulados enquadram-se nas zonas de conforto do ambiente propostas pela ASHRAE (2004b).

As diferenças entre as temperaturas da zona ocupada e as temperaturas do ar da zona superior indicam a ocorrência efetiva da estratificação do ar no ambiente.

No Caso 3 a estratificação do ar é maior, com transição entre as zonas na altura de aproximadamente $1 \mathrm{~m}$. Neste caso, a temperatura do ar insuflado, assim como a temperatura do ar na zona ocupada, são mais baixas em relação aos outros casos simulados. Isto é resultado, principalmente, do fato do controle da zona ocupada ter sido especificado para a manutenção da mesma dentro da zona de conforto especificada pela ASHRAE (2004b). Este controle possibilita que o sistema trabalhe com temperaturas variadas, desde que estejam dentro da faixa de conforto. Logo, o sistema faz uso da temperatura de $13^{\circ} \mathrm{C}$ especificada para a saída do ar na serpentina, das condições climáticas do ar exterior, e do controle do ciclo economizador por diferença de temperatura entre o ar exterior e o ar de retorno, para consumir a menor quantidade de energia elétrica, mantendo o ambiente confortável termicamente. $\mathrm{O}$ fato de o ciclo economizador permitir uma maior vazão do ar exterior faz com que o ar expurgado do retorno seja substituído por um ar exterior mais frio que o ar de retorno, possibilitando temperaturas mais baixas de insuflação. Nota-se ainda que, devido às baixas temperaturas do ar insuflado, a vazão do ar também é mais baixa, para evitar o desconforto local.

Verificadas as condições de conforto térmico no ambiente, foi então avaliado o conforto dos usuários para os seis casos simulados, utilizando-se o método de avaliação proposto por Fanger (1972)

As médias mensais dos resultados dos valores de PMV dos seis casos simulados para o período de um ano típico são apresentadas na figura 28. De outubro a abril a sensação térmica no ambiente foi avaliada em aproximadamente 0,1 , e de maio a setembro foi avaliada em aproximadamente 0,5. Este aumento da sensação térmica ocorre devido à vestimenta de

\footnotetext{
${ }^{2}$ Esta consideração se deve ao fato de haver sido constatado que a temperatura do ar e a temperatura radiante média apresentaram valores muito próximos nos experimentos de Leite (2003).
} 
inverno, indicando que o uso do paletó dentro do ambiente condicionado torna-se desconfortável, causando uma leve sensação de calor.

Os resultados indicam que o conforto térmico dos usuários foi atingido em todos os modelos, visto que o voto médio estimado na escala de sensação térmica encontra-se entre $+0,5$ e $-0,5$.

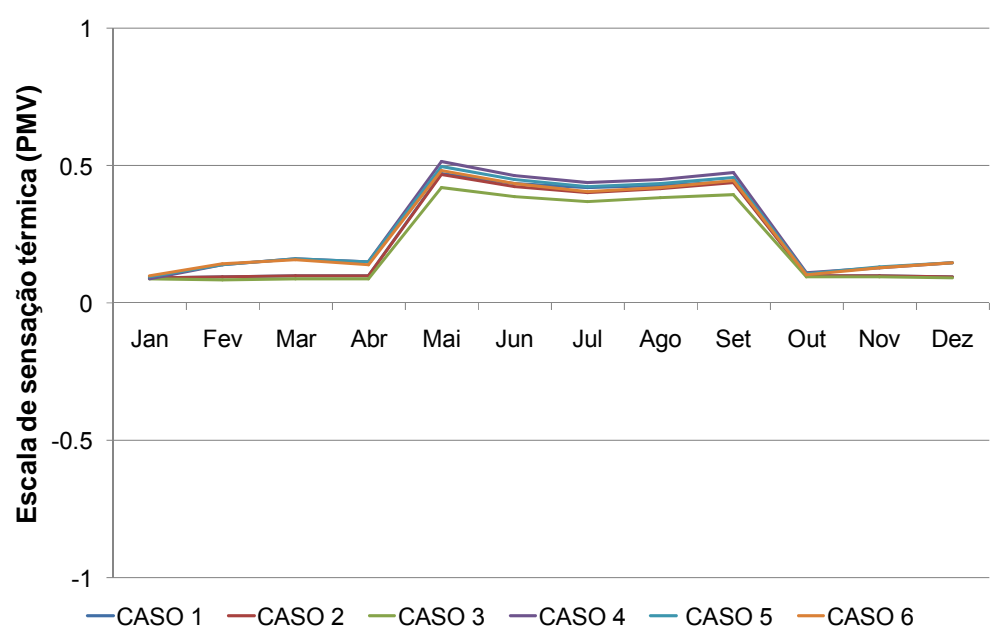

Figura 28 - Conforto térmico no ambiente - PMV.

\subsection{ANÁLISE DA VAZÃO DE AR EXTERIOR}

Estudos do comportamento dos casos simulados com relação às vazões de tomada do ar exterior foram realizados. Estas vazões foram analisadas conjuntamente com os resultados horários de temperaturas do ar de retorno, e temperatura de bulbo seco e umidade relativa do ar exterior (figuras 21 a 24 do item 4.1, "Análise de dados climáticos").

Os resultados horários das vazões de tomada do ar exterior foram tratados de maneira que as figuras 29 e 30 apresentam as médias horárias para cada mês.

A seguir serão apresentadas análises do comportamento dos modelos simulados, observando-se a vazão do ar exterior relacionada com os dados climáticos e temperaturas de retorno. 


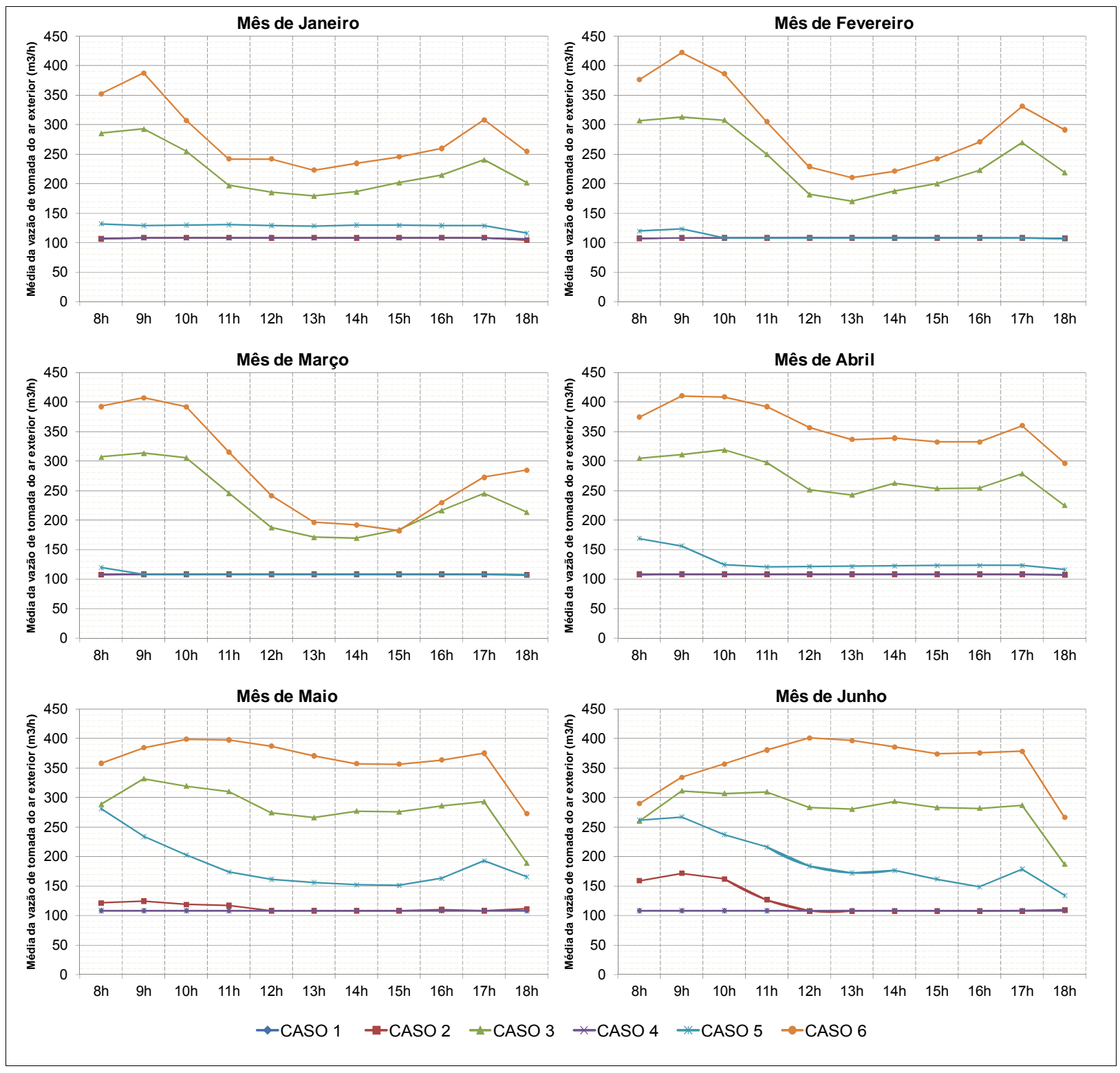

Figura 29 - Casos simulados. Médias horárias das vazões de tomada do ar exterior $\left(\mathrm{m}^{3} / \mathrm{h}\right)$. Meses de Janeiro a Junho. 


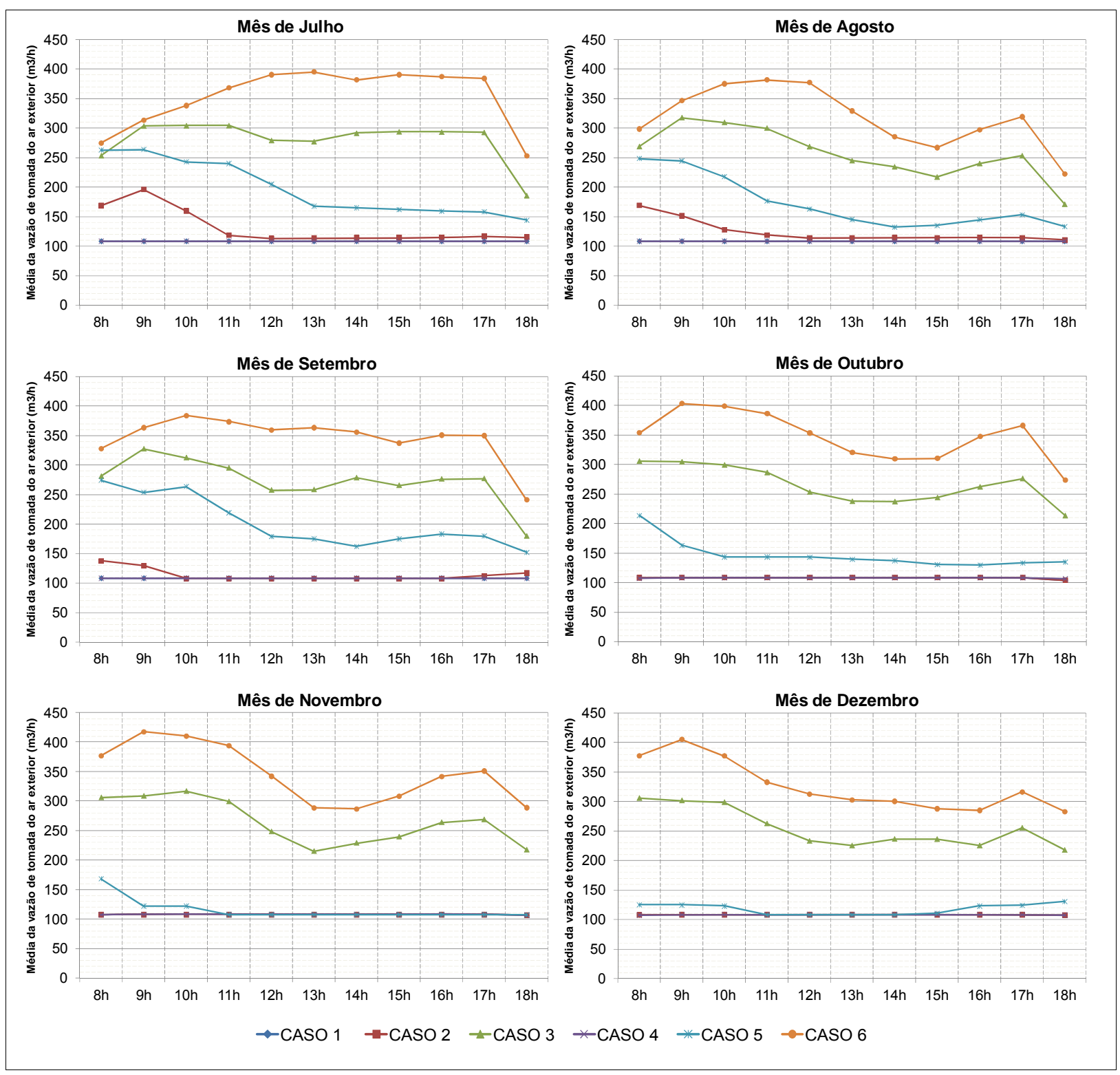

Figura 30 - Casos simulados. Médias horárias das vazões de tomada do ar exterior (m3/h). Meses de Julho a Dezembro.

Nos casos 1 e 4, sendo a taxa de renovação de ar fixa a $27 \mathrm{~m}^{3} / \mathrm{h} /$ pessoa, a vazão de ar exterior permanece constante a $108 \mathrm{~m} 3 / \mathrm{h}$ durante todo o ano.

No caso 2, onde a vazão de ar exterior é variável quando o mesmo atinge temperaturas menores ou iguais a $13^{\circ} \mathrm{C}$, nota-se que há um pequeno aumento na vazão de tomada do ar exterior nos meses de maio a setembro, principalmente no período entre as $8 \mathrm{~h}$ e $11 \mathrm{~h}$, atingindo uma vazão máxima não maior que $200 \mathrm{~m}^{3} / \mathrm{h}$.

No caso 5, onde a vazão de ar exterior é variável quando o mesmo atinge temperaturas menores ou iguais a $17^{\circ} \mathrm{C}$, há um aumento de vazão do ar exterior no mês de janeiro e entre os meses de abril e outubro. O aumento de vazão mais significativo ocorre no 
período entre maio e setembro, principalmente no período da manhã, atingindo a vazão máxima de $280 \mathrm{~m}^{3} / \mathrm{h}$.

Nos casos 3 e 6, onde a vazão do ar exterior é variável quando a temperatura do ar de retorno está mais alta que a temperatura do ar exterior, o aumento da vazão ocorre de modo significativo durante todo o ano, oscilando nos meses de janeiro a março na faixa de $160 \mathrm{~m}^{3} / \mathrm{h}$ a $425 \mathrm{~m}^{3} / \mathrm{h}$, e nos meses de abril a dezembro na faixa de $180 \mathrm{~m}^{3} / \mathrm{h}$ a $425 \mathrm{~m}^{3} / \mathrm{h}$.

A vazão do ar exterior é maior no caso 6, apesar de os casos 3 e 6 possuírem a mesma configuração de controle dos ciclos economizadores, e as temperaturas de retorno dos dois casos estarem acima da temperatura do ar exterior. Isto ocorre porque o circuito de ar no caso 6 (sem desvio do ar de retorno) trabalha com temperatura de ar na saída da serpentina de resfriamento a $17^{\circ} \mathrm{C}$, ou seja, $4^{\circ} \mathrm{C}$ mais alta que no caso 3 , o que permite maior expurgo do ar de retorno, e maior taxa de renovação do ar. A temperatura de $13^{\circ} \mathrm{C}$ na saída da serpentina faz com que o sistema seja obrigado a expurgar menos ar de retorno para que este seja reutilizado no reaquecimento do ar resfriado, no intuito de atingir a temperatura mínima admissível para o ar de insuflação, sem causar danos ao conforto térmico do ambiente.

\subsection{CARGA TÉRMICA DE REFRIGERAÇÃO E CONSUMO DE ENERGIA ELÉTRICA}

A carga térmica de refrigeração solicitada pelos modelos foi então analisada considerando-se a influência da variação da tomada de vazão do ar exterior.

Das simulações dos seis casos foram extraídos os dados horários de carga térmica de refrigeração, e os resultados foram então tratados de maneira que a tabela 9 a seguir indica a média mensal (Wh/h) dos casos simulados, dispostos em forma de gráfico na figura 31 .

Tabela 9 - Média mensal das cargas térmicas de refrigeração dos casos simulados $(\mathrm{Wh} / \mathrm{h})$.

\begin{tabular}{lrrrrrr}
\hline \multicolumn{7}{c}{ Carga térmica de refrigeração (Wh/h) } \\
Mês & Caso 1 & Caso 2 & Caso 3 & Caso 4 & Caso 5 & Caso 6 \\
\hline Jan & 1412 & 1412 & 1650 & 1198 & 1146 & 1092 \\
Fev & 1593 & 1593 & 1945 & 1340 & 1334 & 1318 \\
Mar & 1531 & 1531 & 1760 & 1290 & 1287 & 1166 \\
Abr & 1342 & 1342 & 1416 & 1119 & 1053 & 760 \\
Mai & 1065 & 1046 & 775 & 917 & 671 & 363 \\
& & & & & & continua
\end{tabular}




\begin{tabular}{lrrrrrr} 
& \multicolumn{3}{c}{ Carga térmica de refrigeração (Wh/h) } & \multicolumn{2}{r}{ continuação } \\
Mês & Caso 1 & Caso 2 & Caso 3 & Caso 4 & Caso 5 & Caso 6 \\
\hline Jun & 975 & 906 & 684 & 877 & 584 & 356 \\
Jul & 902 & 808 & 570 & 830 & 519 & 287 \\
Ago & 980 & 915 & 723 & 905 & 680 & 490 \\
Set & 1003 & 980 & 734 & 899 & 597 & 366 \\
Out & 1188 & 1188 & 1092 & 1012 & 891 & 577 \\
Nov & 1309 & 1309 & 1347 & 1098 & 1076 & 756 \\
Dez & 1437 & 1437 & 1609 & 1191 & 1162 & 931 \\
\hline
\end{tabular}

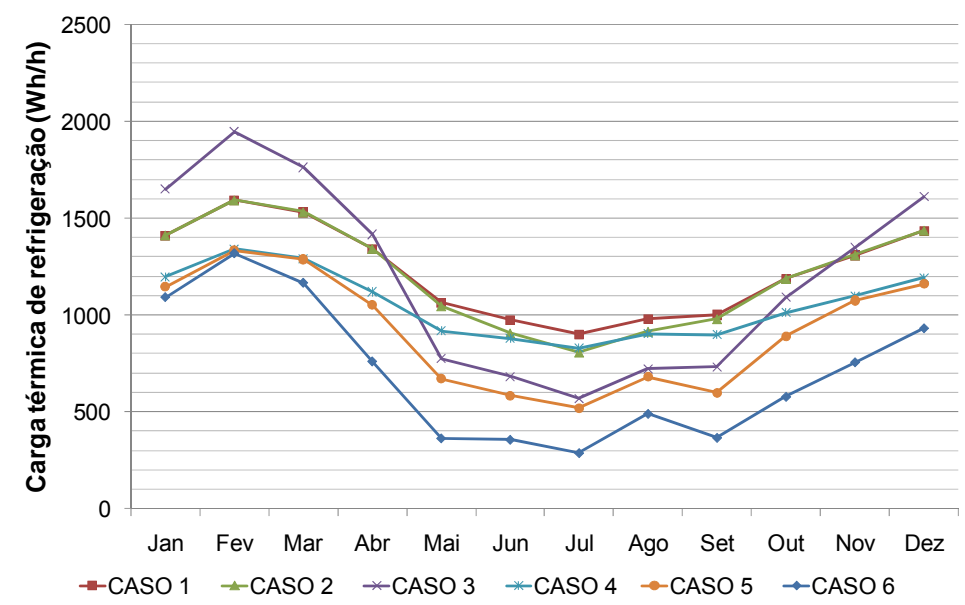

Figura 31 - Média mensal das cargas térmicas de refrigeração dos casos simulados (Wh/h).

As cargas térmicas de refrigeração dos casos 1 e 4 acompanham moderadamente as oscilações das temperaturas do ar exterior, visto que a vazão deste é fixa apenas para garantir a taxa mínima de renovação do ar. Estes casos foram utilizados como parâmetro para a verificação da influência dos ciclos economizadores sobre a carga térmica de refrigeração e consumo de energia.

Considerando os resultados das vazões de tomada de ar exterior apresentados anteriormente, nota-se que a carga térmica de refrigeração diminui consideravelmente no caso 6 com a utilização do ciclo economizador com controle da temperatura de retorno. No caso 3, o mesmo controle proporciona redução de carga térmica no inverno, e aumento da mesma no verão.

A carga térmica a ser retirada pelo sistema é maior nos casos 1 e 2, como conseqüência do circuito de ar que, nestes casos, exige a temperatura do ar na saída da serpentina de refrigeração a $13^{\circ} \mathrm{C}$. 
Os resultados das simulações dos seis casos foram separados em dois grupos considerando a configuração do circuito de ar e conseqüentes especificações de funcionamento dos sistemas: casos de 1 a 3 , e casos 4 a 6 . O intuito é verificar a influência dos ciclos economizadores na carga térmica de refrigeração, considerando as diferenças do circuito de ar de cada sistema simulado.

A figura 32 indica a carga térmica de refrigeração mensal dos casos 1 a 3 , em $\mathrm{Wh} / \mathrm{h}$. Demonstra também, em porcentagem, a redução de carga térmica de refrigeração dos casos 2 e 3 comparativamente ao caso 1 .

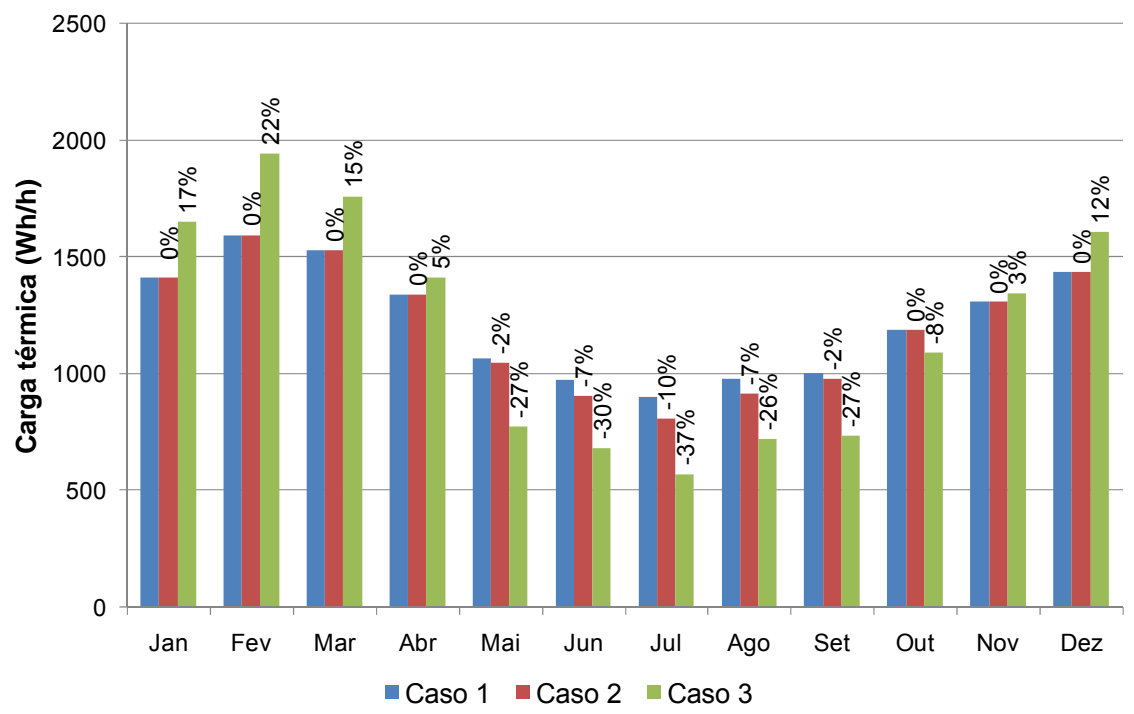

Figura 32 - Carga térmica de refrigeração dos casos 1 a $3(\mathrm{Wh} / \mathrm{h})$. Redução da carga térmica de refrigeração dos casos 2 e 3 comparativamente ao caso 1 (\%).

Por exemplo, analisando os resultados do mês de julho, tem-se que:

a) A utilização do ciclo economizador, configurado para majorar a tomada do ar exterior quando a temperatura do ar exterior for igual ou menor a $13^{\circ} \mathrm{C}(\mathrm{Caso} 2)$, reduz em aproximadamente $10 \%$ a carga térmica de refrigeração, se comparado com um sistema que utiliza o ar exterior apenas para renovação mínima do ar (Caso 1).

b) A utilização do ciclo economizador com o controle da temperatura do ar de retorno (Caso 3) reduz em aproximadamente $37 \%$ a carga térmica de refrigeração se comparada com um sistema que utiliza o ar exterior apenas para renovação mínima do ar.

Analisando conjuntamente os resultados da figura 32, e utilizando como parâmetro de comparação o caso 1, pode-se afirmar que a redução de carga térmica de refrigeração do 
caso 2 ocorre de maio a setembro, quando os ciclos economizadores são acionados. A redução varia de $2 \%$ a $10 \%$ neste período, sendo praticamente nula nos meses restantes.

A carga térmica de refrigeração no caso 3 aumenta ou diminui conforme a vazão do ar exterior permitida pelo ciclo economizador. Entre os meses de novembro a abril, a carga é maior que no caso 1 , variando de $3 \%$ a $22 \%$ a mais, quando as temperaturas externas do ar são elevadas, porém inferiores às temperaturas de retorno do ar. Nos meses de maio a outubro há redução na carga térmica de refrigeração, variando de menos $8 \%$ a menos $37 \%$ em relação ao caso 1 .

A figura 33 indica a carga térmica de refrigeração mensal dos casos 4 a 6 , em $\mathrm{Wh} / \mathrm{h}$. Demonstra também, em porcentagem, a redução de carga térmica de refrigeração dos casos 5 e 6 comparativamente ao caso 4 .

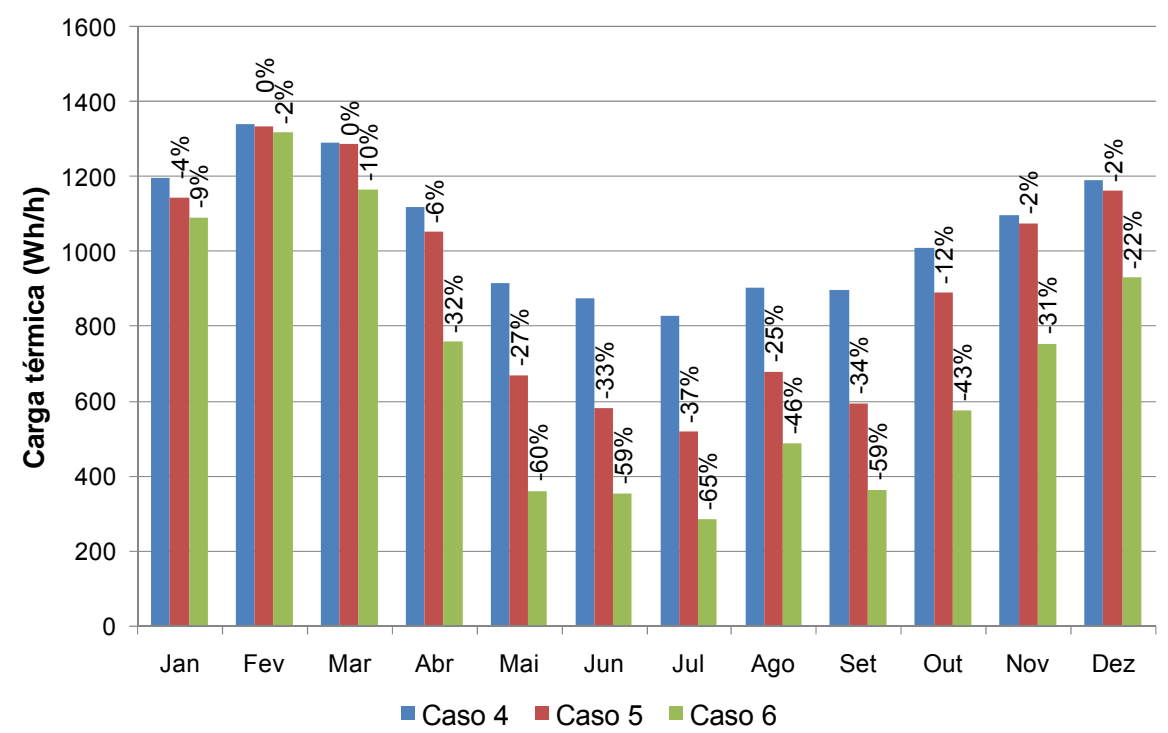

Figura 33 - Carga térmica de refrigeração dos casos 4 a $6(\mathrm{Wh} / \mathrm{h})$. Redução da carga térmica de refrigeração dos casos 5 e 6 comparativamente ao caso 4 (\%).

Nos sistemas UFAD com circuitos de ar sem o desvio de retorno, a utilização dos ciclos economizadores propicia redução na carga térmica de refrigeração durante praticamente todo o ano.

No caso 5, os ciclos economizadores propiciam uma redução de carga térmica que varia de $2 \%$ a $12 \%$ entre os meses de outubro a janeiro, tornando-se insignificante nos meses de fevereiro e março, e acentuando-se nos meses de maio a setembro, quando varia de $27 \%$ a $37 \%$. 
No caso 6 , os ciclos economizadores reduzem a carga térmica de refrigeração de $2 \%$ a $10 \%$ nos três primeiros meses do ano. Entre os meses de abril a dezembro, esta redução é majorada, variando entre $22 \%$ e $65 \%$.

A figura 34 indica as médias mensais anuais das cargas térmicas de refrigeração dos casos 1 a 6, em Wh/h. Demonstra também, em porcentagem, a redução de carga térmica de refrigeração dos casos 2 a 6 comparativamente ao caso 1 .

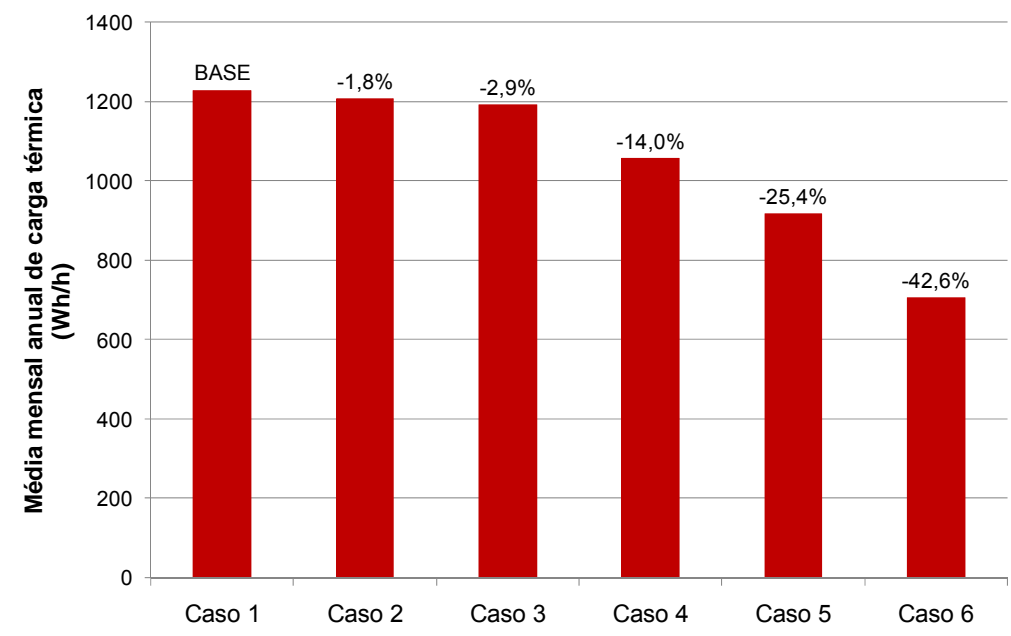

Figura 34 - Médias mensais anuais das cargas térmicas de refrigeração dos casos 1 a 6 (Wh/h). Redução da carga térmica de refrigeração dos casos 2 a 6 comparativamente ao caso 1 (\%).

Comparando os Casos 1 e 4, nota-se que o sistema com o circuito de ar sem o desvio do retorno (Caso 4) possui carga térmica de refrigeração 14\% menor que o Caso 1, sendo que ambos têm a tomada de ar externo constante para atender a taxa de renovação mínima de ar. Isso se deve ao fato de o Caso 4 trabalhar com a temperatura na saída do ar na serpentina a $17^{\circ} \mathrm{C}$, ou seja, $4^{\circ} \mathrm{C}$ mais alta que no Caso 1 . O circuito de ar também é responsável pela carga térmica dos casos 2 e 3 não serem reduzidas significativamente com o acionamento dos ciclos economizadores.

Tomando como base a carga térmica de refrigeração do Caso 1, nota-se que a utilização dos ciclos economizadores são mais eficientes nos casos 5 e 6 , atingindo uma redução média de $42,6 \%$.

O consumo dos equipamentos de um sistema de condicionamento de ar é resultado da carga térmica de refrigeração solicitada pelo sistema. Para a análise do consumo de energia dos equipamentos foram extraídos os resultados do consumo das unidades de resfriamento, dos ventiladores e das bombas, para o intervalo de funcionamento do sistema, durante o período de um ano típico. 
Os resultados das simulações foram então tratados de maneira que os gráficos a seguir (figuras 35, 36 e 37) apresentam as médias mensais do consumo de energia dos equipamentos.
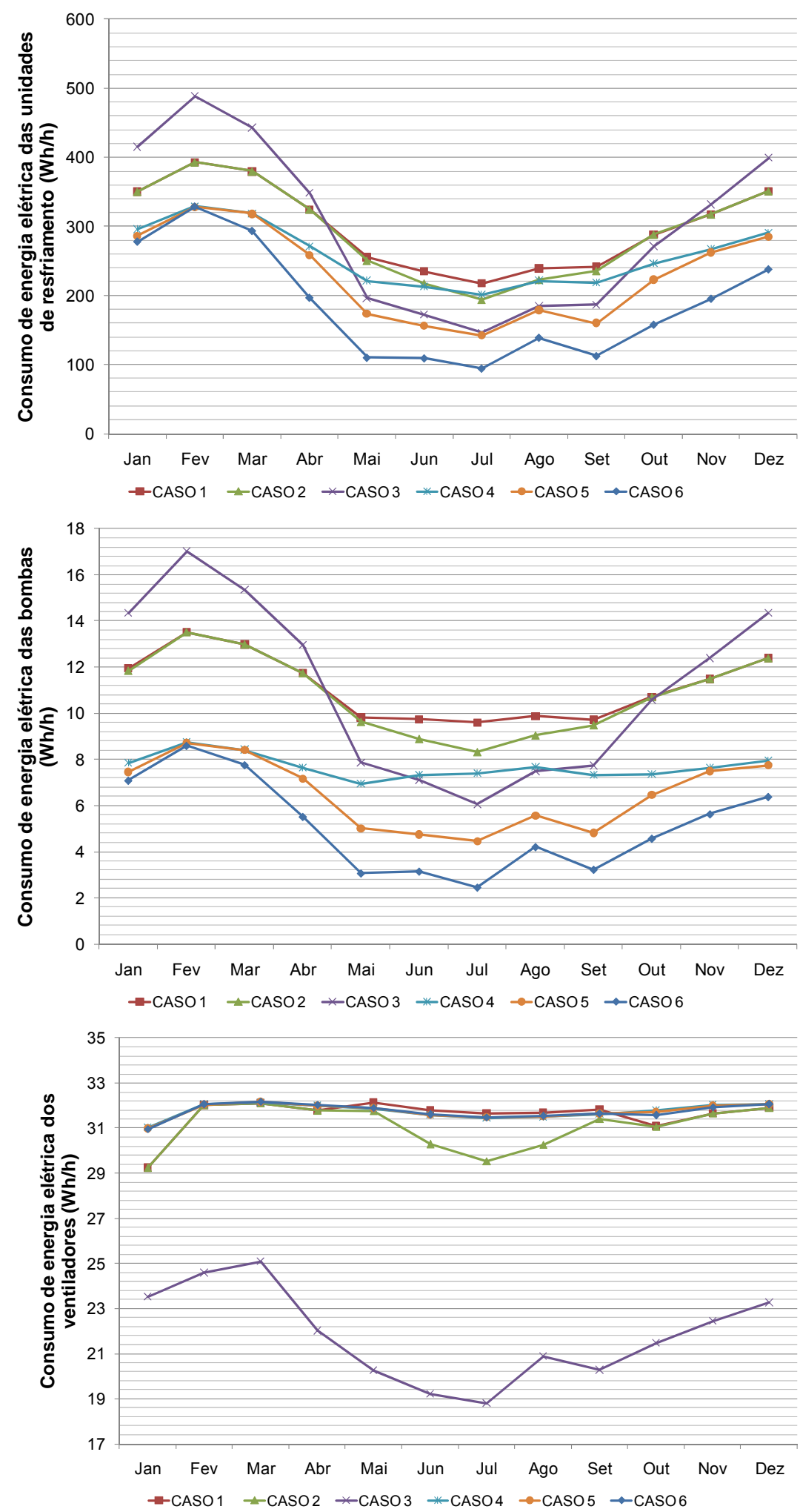

Figura 35 - Médias mensais do consumo de energia das unidades de resfriamento $(\mathrm{Wh} / \mathbf{h})$.

Figura 36 - Médias mensais do consumo de energia das bombas $(\mathrm{Wh} / \mathrm{h})$.

Figura 37 - Médias mensais do consumo de energia dos ventiladores $(\mathrm{Wh} / \mathrm{h})$. 
Comparando-se o consumo dos seis casos, pode-se afirmar que:

a) As especificações do circuito de ar e do tipo de controle do ciclo economizador a ser utilizado são determinantes no consumo de energia do sistema UFAD;

b) O consumo de energia elétrica das unidades de resfriamento e bombas é extremamente sensível às condições do ar exterior, mesmo nos casos em que a vazão de ar exterior é constante;

c) As curvas do consumo de energia das unidades de resfriamento e das bombas possuem o mesmo comportamento das curvas de carga térmica de refrigeração de cada caso;

d) O consumo dos ventiladores do caso 3 é reduzido em relação aos outros casos simulados, como resultado das condições de controle do ambiente e do sistema de condicionamento de ar.

A figura 38 apresenta os resultados do consumo anual de energia elétrica dos casos simulados.

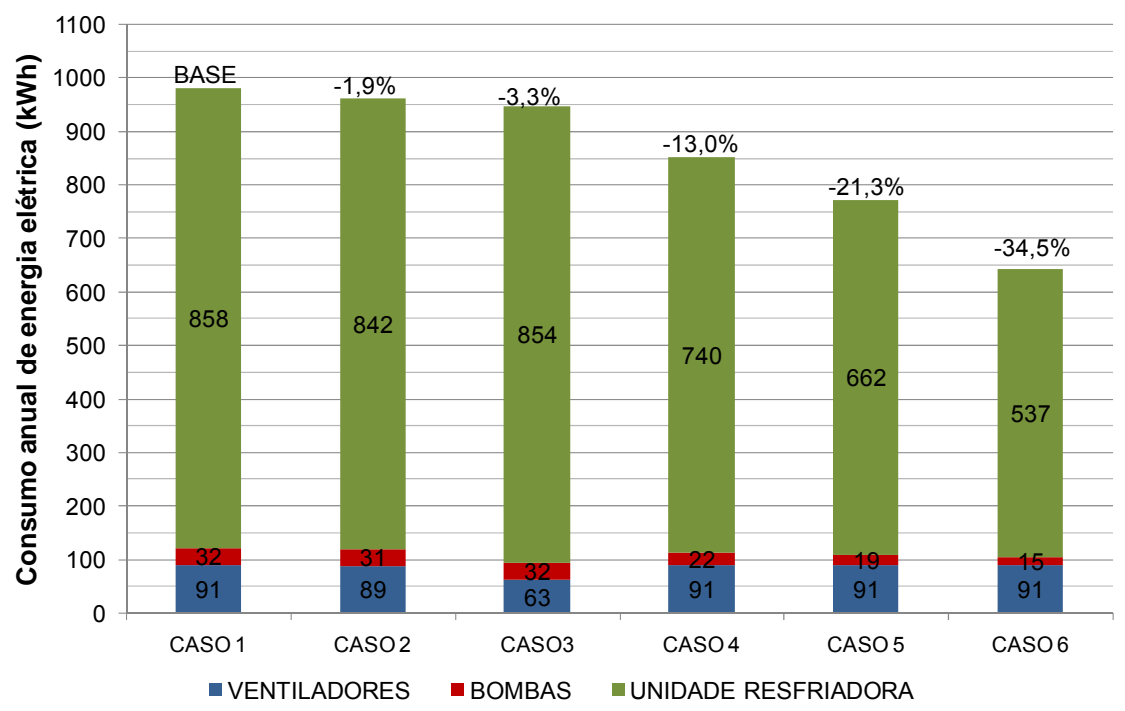

Figura 38 - Consumo anual de energia elétrica do sistema de condicionamento de ar dos casos simulados (kWh). Redução do consumo de energia elétrica dos casos 2 a 6 comparativamente ao caso 1 (\%).

Analisando cada caso, e tomando como referência o consumo resultante do Caso 1, há indicações de que o consumo anual de energia elétrica do sistema UFAD, na cidade de São Paulo, pode ser reduzido em $34,5 \%$ por meio da utilização do controle de vazão da tomada do ar exterior.

Nota-se que, nos Casos 1 e 4, onde a taxa de renovação do ar é constante, a temperatura do ar na saída da serpentina de resfriamento é determinante no consumo a menor 
do Caso $4\left(17^{\circ} \mathrm{C}\right)$ em relação ao Caso $1\left(13^{\circ} \mathrm{C}\right)$. Tal temperatura influencia diretamente no consumo da unidade de resfriamento do ar e das bombas, proporcionando 13,0\% de redução no consumo de energia do Caso 4.

As reduções do consumo de energia elétrica nos casos 2 e 3 são pouco significativas. No caso 3, é a redução do consumo por parte dos ventiladores que o torna mais eficiente que o caso 2.

No Caso 5, onde o ciclo economizador é controlado pela temperatura do ar exterior menor ou igual a $17^{\circ} \mathrm{C}$, a redução no consumo atinge a média de $21,3 \%$.

No Caso 6, onde o controle da vazão do ar exterior é função da temperatura do ar exterior e da temperatura do ar de retorno, nota-se que a redução no consumo de energia é acentuada. Com a utilização destes controles, a utilização dos ciclos economizadores é majorada, atingindo redução do consumo de energia de 34,5\%. 


\section{CONCLUSÕES}

A utilização do sistema de condicionamento de ar com insuflação pelo piso (Underfloor Air Distribution - UFAD) em edifícios de escritórios é crescente no Brasil, visto seu comprovado benefício em relação ao conforto térmico no ambiente, seu potencial de economia de energia e possibilidade de controle individual de vazão de ar pelos ocupantes.

A cidade de São Paulo é possuidora do maior centro comercial do país, e grande quantidade de edifícios de escritórios concentra-se nela. Portanto, pesquisas que conduzam à redução do consumo de energia de edificações localizados nesta cidade são desejáveis.

Esta pesquisa procurou quantificar a redução do consumo de energia elétrica do sistema UFAD em função da utilização dos ciclos economizadores de ar, aplicados na cidade de São Paulo.

As análises foram realizadas por meio de simulações computacionais que, cada vez mais sofisticadas, possibilitaram análises iterativas dos casos. As simulações permitiram a avaliação da transitoriedade das condições climáticas da cidade de São Paulo, sua relação com a vazão de ar exterior, seu impacto na carga térmica de refrigeração e, conseqüentemente, no consumo de energia do sistema.

Considerações baseadas nos resultados desta pesquisa serão arroladas a seguir.

$\mathrm{O}$ consumo de energia do sistema UFAD está relacionado principalmente às características intrínsecas a ele, tais como: temperaturas de insuflação de ar superior às utilizadas nos sistemas com insuflação pelo teto, condicionamento do volume de ar apenas da zona ocupada, e aproveitamento da convecção natural e estratificação do ar.

$\mathrm{O}$ fato das temperaturas do ar insuflado no ambiente serem entre $16^{\circ} \mathrm{C}$ e $21^{\circ} \mathrm{C}$ aumenta a possibilidade de utilização dos ciclos economizadores na cidade de São Paulo.

As duas possibilidades de definição dos circuitos de ar permitidos pelo sistema UFAD - com ou sem desvio do ar de retorno - propiciam diferentes consumos de energia elétrica do sistema em função da carga térmica de refrigeração. Tal conclusão é evidenciada pela comparação dos Casos 1 e 4, onde o consumo de energia é diretamente influenciado pelas temperaturas especificadas para o ar na saída da serpentina de resfriamento $\left(13^{\circ} \mathrm{C}\right.$ ou $17^{\circ} \mathrm{C}$ ), e pelas temperaturas da água nas unidades de resfriamento.

Quando o controle dos ciclos economizadores se dá pela temperatura de bulbo seco do ar exterior, a vazão do ar exterior fica vinculada principalmente ao circuito de ar projetado. Se o circuito fizer uso do desvio de ar de retorno para atingir a temperatura de insuflação, as operações economizadoras ficam mais limitadas, pois a temperatura do ar na saída da 
serpentina condiciona a vazão do ar exterior para quando este estiver com temperatura menor ou igual a $13^{\circ} \mathrm{C}$. Já quando o circuito do ar não possui o duto de desvio do ar de retorno, a possibilidade de aumento da vazão de tomada do ar exterior variará quando este estiver com a temperatura menor ou igual a $17^{\circ} \mathrm{C}$, majorando as horas de operação dos ciclos economizadores. Isto é evidenciado nas comparações entre os Casos 2 e 5.

Considerando as condições climáticas da cidade de São Paulo, os ciclos economizadores se tornam mais eficientes quando a vazão do ar exterior é controlada pelas temperaturas do ar exterior e do ar de retorno. Os dados climáticos de um ano típico desta cidade indicam que as temperaturas do ar exterior encontram-se abaixo da temperatura de retorno durante cerca de $84 \%$ das horas de ocupação de um ambiente de escritórios. Novamente, o circuito de ar especificado será decisivo para a majoração de utilização dos ciclos economizadores. Se o circuito possuir duto de desvio do ar de retorno, a temperatura definida na serpentina de resfriamento será de $13^{\circ} \mathrm{C}$, sendo necessário o seu reaquecimento para que o ar insuflado atinja a faixa de $16^{\circ} \mathrm{C}$ a $20^{\circ} \mathrm{C}$. Isto diminui o volume de ar de retorno que pode ser expurgado, pois parte dele será necessário para o reaquecimento do ar. Portanto, mesmo que a temperatura do ar exterior esteja mais baixa que a temperatura do ar de retorno, o volume do ar de retorno não poderá ser totalmente substituído pelo ar exterior.

Dos resultados desta pesquisa conclui-se que a eficiência energética do sistema UFAD, quando analisada em função dos dados climáticos do local de instalação, está vinculada principalmente: ao controle especificado para o ambiente, ao circuito de ar projetado, e ao tipo de controle utilizado nos ciclos economizadores. Estes três itens influenciam diretamente na vazão de tomada do ar exterior, na carga de refrigeração do sistema, e no consumo de energia elétrica. A correlação entre eles possibilita o desenvolvimento de um projeto com consumo de energia elétrica reduzido, garantindo o conforto térmico dos usuários.

Para o clima da cidade de São Paulo, os resultados indicam que os ciclos economizadores no sistema UFAD podem reduzir o consumo de energia elétrica do condicionamento de ar em até $34,5 \%$. Esta redução é considerável, visto que o sistema de condicionamento de ar é responsável por grande parcela do consumo de energia elétrica de um edifício de escritórios.

A generalização de que a tomada de ar exterior aumenta o consumo de energia de sistemas de ar condicionado deve ser revista, pois, os resultados desta pesquisa indicam que, no sistema UFAD, as condições climáticas podem influenciar positivamente na redução do consumo de energia dos sistemas de condicionamento de ar. 
A análise dos dados climáticos e simulação do comportamento dos sistemas de condicionamento de ar para o período de um ano típico são fundamentais para os cálculos de consumo de energia elétrica destes sistemas. Podem auxiliar no dimensionamento dos equipamentos, evitando o super dimensionamento, e esclarecer quais os sistemas de controle mais adequados para determinado clima.

\section{Sugestões para trabalhos futuros}

O desenvolvimento deste trabalho permitiu a visualização de outras possibilidades de pesquisa voltadas para o desenvolvimento de produto, sistemas de controle e metodologia de projeto. São elas:

- Estudo da influência dos ciclos economizadores controlados por entalpia no consumo de energia elétrica do sistema UFAD.

- Metodologia de projeto de sistemas de condicionamento de ar, baseada em simulações computacionais, considerando as condições climáticas ao longo de um ano típico.

- Sistemas híbridos de condicionamento de ar: controle para manutenção das condições de conforto térmico e o consumo de energia elétrica. Analisar a utilização concomitante de diferentes sistemas de condicionamento de ar: mecânico, natural, por painéis radiantes, distribuído pelo piso ou pelo teto.

- Análise das variações do consumo de energia elétrica do sistema UFAD para diferentes condições climáticas, utilizando simulação computacional. 


\section{REFERÊNCIAS BIBLIOGRÁFICAS}

ABE, V. C.; Determinação de parâmetros de operação de sistema de distribuição de ar frio pelo piso em ambientes de escritórios. 2007. 130 p. Dissertação (Mestrado) - Escola Politécnica, Universidade de São Paulo, São Paulo, 2007.

ARCHITECTURAL ENERGY CORPORATION, BOULDER, CO. Design Brief: Underfloor air distribution and access floors. Energy Design Resources. California: eNews for Designers, Issue 36, 2004.

ASHRAE - AMERICAN SOCIETY OF HEATING, REFRIGERATION AND AIR CONDITIONING. ANSI/ASHRAE Standard 140-2004. Standard Method of Test for the Evaluation of Building Energy Analysis Computer Programs. Atlanta: ASHRAE, Inc., 2004a.

ANSI/ASHRAE Standard 55-2004. Thermal environmental conditions for human occupancy. Atlanta: ASHRAE, Inc., 2004b.

. ASHRAE Standard 62.1-2004. Ventilation for Acceptable Indoor Air Quality. Atlanta: ASHRAE, Inc., 2004c.

ASHRAE Standard 90.1-2004. Energy Standard for Buildings Except Low-Rise Residencial Buildings. Atlanta: ASHRAE, Inc., 2004d.

ASHRAE Handbook of Fundamentals - 2005. Atlanta: ASHRAE, Inc.,

2005.

ATIKOL, U. A demand-side planning approach for the commercial sector of developing countries. Energy. Oxford : Pergamon Press, v. 29, p. 257-266, 2004.

BADENHORST, S. Underfloor Air Distribution. In: CONFERENCE ON INDOOR AIR QUALITY, 2002, Canberra. Australia: AIRAH - Australian Institute of Refrigeration, Air Conditioning and Heating, 2002.

BAUMAN, F. S. Designing UFAD Systems: Updated Guidelines. Presentation for the Professional Development Seminar. Central PA ASHRAE UFAD Workshop, York, Nov. 2006. Pennsylvania, 2006. Disponível em: <http://www.cbe.berkeley.edu $>$ Acesso em: out. 2007.

. Underfloor Air Distribution (UFAD) Design Guide. Atlanta: American Society of Heating, Refrigeration and Air Coditioning, 2003. 243 p. 
; WEBSTER T. Outlook for Underfloor Air Distribution. ASHRAE Journal, New York, v. 43, n. 6, p.18-25, 2001.

Giving occupants what they want: guidelines for implementing personal environmental control in your building. Center for the Built Environment, University of California, Berkeley, Abril, 1999.

BRASIL. Agência Nacional de Vigilância Sanitária (2003). Resolução RE ANVISA N9, 16 de janeiro de 2003. Diário Oficial da União, 20/01/2003.

BRASIL. Ministério de Minas E Energia. Empresa De Pesquisa Energética - EPE. Balanço Energético Nacional 2007: Ano Base 2006: Sumário Executivo / Ministério de Minas e Energia. Empresa de Pesquisa Energética. Rio de Janeiro: EPE, 2007.

BULLA, L. A. S. Análise paramétrica do desempenho termo-energético de um edifício de escritórios. Florianópolis, 1995. 81 p. Dissertação (Mestrado) - Universidade Feredal de Santa Catarina, USFC, 1995.

CENTER FOR THE BUILT ENVIRONMENT. Energy Performance of Underfloor Air Distribution Systems. Part V: EnergyPlus Development. Final Project Report submitted to California Energy Commission (CEC). Public Interest Energy Research (PIER) Program, Berkeley, 2007. California: University of California, 2007.

Underfloor Air Technology. Design Phase Guidelines. California: University of California, 2008. Disponível em: $<$ http://www.cbe.berkeley.edu $>$. Acesso em: jan. 2008.

CHANG, H.; KATO, S. CHIKAMOTO, T. Effects of outdoor air conditions on hybrid air conditioning based on task/ambient strategy with natural and mechanical ventilation in office buildings. Building and Environment. Oxford : Pergamon Press, v. 39, p. 153-164, 2004.

CRAWLEY, D. B.; LAWRIE, L. K.; PEDERSEN, C. O.; WINKELMANN, F. C.; WITTE, M. J.; STRAND, R. K.; LIESEN, R. J.; BUHL, W. F.; HUANG, Y. J.; HENNINGER, R. H.; GLAZER, J.; FISHER, D. E.; SHIREY III, D. B.; GRIFFITH, B. T.; ELLIS, P. G.; GU, L. EnergyPlus: An Update. Proc. SimBuild 2004, Building Sustainability and Performance Through Simulation, 2004, Boulder, CO, USA. Disponível em: $<$ http://simulationresearch.lbl.gov/>. Acesso em: nov. 2004.

CRAWLEY, D. B.; HAND, J. W.; KUMMERT, M.; GRIFFITH, B. T. Contrasting the capabilities of building energy performance simulation programs. Relatório técnico produzido por: United States Department of Energy, University of Strathclyde e University of Wisconsin. Julho, 2005. Disponível em: $<\mathrm{http}$ ://www.eere.energy.gov/buildings/tools_directory/pdfs/contrasting_the_capabilities_of_ building_energy_performance_simulation_programs_v1.0.pdf $>$. Acesso em: fev. 2007. 
DALY, A. Underfloor air distribution: Lessons learned. ASHRAE Journal, v. 44, $\mathrm{n}^{\circ}$ 5, p. 21 24, Maio, 2002.

ENERGYPLUS. EnergyPlus Manual: Documentation Version 1.4. Outubro, 2006.

ERNEST ORLANDO LAWRENCE BERKELEY NATIONAL LABORATORY. EnergyPlus Testing with HVAC BESTEST Part 2 - Tests E300 to E545. U.S. Department of Energy, Energy Efficiency and Renewable Energy. Washington, D.C.: 2005.

\section{EnergyPlus Testing with ANSI/ASHRAE Standard 140-2001}

(BESTEST). U.S. Department of Energy, Energy Efficiency and Renewable Energy. Washington, D.C.: 2004.

. EnergyPlus Testing with HVAC BESTEST Part 1 - Tests E100 to E200. U.S. Department of Energy, Energy Efficiency and Renewable Energy. Washington, D.C.: 2004a.

FANGER, P. O. Thermal Comfort Analysis and Applications in Environmental Engineering. McGraw-Hill, New York, 1972.

GARD ANALYTICS, INC. E UNIVERSITY OF ILLINOIS EM URBANA-CHAMPAIGN CONTRATADA PELA NATIONAL RENEWABLE ENERGY LABORATORY. University Course Lectures. U.S.D.O.E. - 2002-2003. Disponível em: $<$ http://www.eere.energy.gov>. Acesso em: nov. 2004.

HEINEMEIER, K.E.; SCHILLER, G., E.; BENTON, C.C. Task conditioning for the workplace: issues and challenges. ASHRAE Transactions, Atlanta, v. 96, pt.2, 678-689, 1990.

HENSEN, J. L. M.; LAMBERTS, R.; NEGRAO, C. O. R. A view of energy and building performance simulation at the start of the third millennium. Editorial. Energy and Buildings. Lausanne: Elsevier science, v. 34, p. 853-855, 2002.

HUANG, J.; WINKELMANN F.; BUHL, F.; PEDERSEN, C.; FISHER, D.; LIESEN, R.; TAYLOR, R.; STRAND, R.; CRAWLEY, D. LAWRIE, L. Linking the COMIS multi-zone airflow model with the EnergyPlus building energy simulation program. Proceedings of Building Simulation '99. Kyoto: IBPSA, 1999. v. II, p.1065-1070.

INATOMI, T. A. H.; ABE, V. C.; LEITE, B. C. C. Energy Consumption of Underfloor Air Distribution Systems: A Literature Overview. In: $23^{\text {rd }}$ INTERNATIONAL CONFERENCE ON PASSIVE AND LOW ENERGY ARCHITECTURE, 2006, Geneva. Proceedings... Switzerland: University of Geneva, 2006. v. II, p. 685-690. 
; MOTEZUKI, F. K.; LEITE, B. C. C.; CHENG, L.Y. Estudo de uma Estratégia para Controle Fuzzy de Ambientes Condicionados com o Sistema UFAD. In: ENCAC 2007 - IX ENCONTRO NACIONAL E V LATINO AMERICANO DE CONFORTO NO AMBIENTE CONSTRUÍDO, 2007, Ouro Preto. Anais... Minas Gerais: Associação Nacional de Tecnologia do Ambiente Construído - ANTAC, 2007. p. 915 -924.

INTERNATIONAL ENERGY AGENCY. Building Energy Simulation Test (BESTEST) and Diagnostic Method. National Renewable Energy Laboratory, Golden, Colorado, 1995.

ISO - INTERNATIONAL STANDARDS ORGANIZATION. ISO 7730: Moderate Thermal Environments-Determination of PMV and PPD Indices and Specification of the Conditions for Thermal Comfort. Geneva, 1984.

JOHN, V. M. Reciclagem de resíduos na construção civil: contribuição para metodologia de pesquisa e desenvolvimento. 2000. 120f. Tese (Livre Docência) - Escola Politécnica da Universidade Federal de São Paulo. São Paulo, 2000.

LAMBERTS, R.; TRIANA, M. A.; FOSSATI, M.; BATISTA, J. O. Sustentabilidade Nas Edificações: Contexto Internacional $E$ Algumas Referências Brasileiras na Área. Disponível em: $<$ http://www.labeee.ufsc.br/sustentabilidade >. Acesso em: jan. 2008.

LAMBERTS, R.; DUTRA, L.; PEREIRA, F. O. R. Eficiência energética na arquitetura. São Paulo: PW, 1997. 192p.

LEITE, B. C. C. Sistemas de ar condicionado com insuflação pelo piso em ambientes de escritórios: avaliação do conforto térmico e condições de operação. São Paulo, 2003. 235 f. Tese (Doutorado) - Escola Politécnica da Universidade de São Paulo, EP-USP, 2003.

; TRIBESS, A. Individually controlled office environments - thermal comfort parameters determination. In: 9th International Conference on Air Distribution in Rooms - ROOMVENT2004. Coimbra : Universidade de Coimbra, 2004.

LIN, Y.J.P.; LINDEN. P.F. A model for an under floor air distribution system. Energy and Buildings, Lausanne: Elsevier science, v. 37, p. 399-409, 2005.

LIU, Q. Energy Performance of Underfloor Air Distribution (UFAD) Systems Part III: The Fluid Dynamics of a UFAD System. 2006. Tese (Doutorado) - Universidade da Califórnia, San Diego, 2006.

LOUDERMILK, K.J. Under-floor air distribution solutions for open office applications. ASHRAE Transactions, v. 105 (1), p. 605-613, 1999. 
MATSUNAWA, K.; H. IIZUKA; TANABE S. Development and application of an underfloor air conditioning system with improved outlets for a smart building in Tokyo. ASHRAE Transactions, Atlanta, v. 101, pt. 2, p. 887-901, 1995.

MCCARRY, B. T. Underfloor air distribution systems: benefits and when to use the system in building design. ASHRAE Transactions, Atlanta, v. 101, pt. 2, p. 902-911, 1995.

MAZRIA, E. Key to the global thermostat: meeting humanity's greatest challenge. In: V SEMINÁRIO INTERNACIONAL DO NÚCLEO DE PESQUISA EM TECNOLOGIA DA ARQUITETURA E URBANISMO DA UNIVERSIDADE DE SÃO PAULO, 2004, São Paulo. Anais... São Paulo: Faculdade de Arquitetura e Urbanismo da Universidade de São Paulo, 2004.

MORRISON, I. B. The adaptive conflation of computational fluid dynamics with wholebuilding thermal simulation. Energy and Buildings, Lausanne: Elsevier Science, v. 34, p. 857-871, 2002.

NEYMARK, J.; R. JUDKOFF. International Energy Agency Solar Heating and Cooling Programme Task 22 Building Energy Simulation Test and Diagnostic Method for HVAC Equipment Models (HVAC BESTEST). National Renewable Energy Laboratory, Golden, Colorado, NREL/TP-550-30152, 2002.

PUSTELNIK, M. Avaliação numérica de ambientes com insuflação de ar pelo piso. São Paulo, 2005. Dissertação (Mestrado) - Escola Politécnica da Universidade de São Paulo, EPUSP, 2005.

SÃO PAULO. SECRETARIA MUNICIPAL DE GOVERNO. Município em dados. Infraestrutura urbana. Prefeitura da Cidade de São Paulo. Disponível: $<$ http://www9.prefeitura.sp.gov.br/sempla/md/index.php?texto=introducao\&ordem_tema $=4 \&$ ordem_subtema $=9>$. Acesso em: jan. 2008.

SÃO PAULO. SECRETARIA MUNICIPAL DE GOVERNO. Organogramas. Consumo de energia elétrica por classe. Prefeitura da Cidade de São Paulo. Disponível: $<$ http://ww1.prefeitura.sp.gov.br/portal/a_cidade/organogramas/index.php? $\mathrm{p}=438 \&$ more $=1 \& \mathrm{c}$ $=1 \& \mathrm{tb}=1 \& \mathrm{pb}=1>$. Acesso em: jan. 2008a.

SHUTE, R. W. Integrated access floor HVAC: lessons learned. ASHRAE Transactions, Atlanta, v. 101, p. 877-886, 1995.

SONG, D.; KATO, S. Radiational panel cooling system with continuous natural cross ventilation for hot and humid regions. Energy and Buildings, Lausanne: Elsevier Science, v. 36, p.1273-1280, 2004. 
; YANG, J. H.; ZHU, S.; CHIKAMOTO, T. Study on the individual control system considering human thermal adaptation. In: 9TH INTERNATIONAL CONFERENCE ON AIR DISTRIBUTION IN ROOMS ROOMVENT2004. Proceedings... Coimbra : Universidade de Coimbra, p. 106-107, 2004.

SPOORMAKER, H. J. Low-pressure underfloor HVAC system. ASHRAE Transactions, Atlanta, v.96, pt. 2, p. 670-677, 1990.

TSUZUKI, K.; ARENS, E. A.; BAUMAN, F. S.; WYON, D. P. Individual thermal control with desk-mounted and floor-mounted task/ambient conditioning (TAC) systems. In: INDOOR AIR 99, 1999, Edinburgh. Proceedings... Scotland: 1999. v. 2, p. 368-373.

WANG, D.; ARENS, E.; WEBSTER, T.; SHI, M. How the Number and Placement of Sensors Controlling Room Air Distribution Systems Affect Energy Use and Comfort. In: INTERNATIONAL CONFERENCE FOR ENHANCED BUILDING OPERATIONS, 2002, Richardson. Proceedings... Texas, 2002.

WEBSTER, T.; BAUMAN, F.; REESE, J. Underfloor air distribution: Thermal stratification. ASHRAE Journal, Atlanta, v.44, nº 5, p. 28-36, 2002.

; RING, E.; BAUMAN, F. Supply fan energy use in pressurized underfloor plenum systems. Center for the Build Environment, University of California, 2000.

; BAUMAN, F.; REESE, J.; SHI, M. Thermal stratification performance of underfloor air distribution (UFAD) systems. In: INDOOR AIR 2002, 2002, Monterey. Proceedings... California, 2002, 6 p.

WINES, J. Green Architecture. Milan : Taschen, 2000. 240p. 


\section{BIBLIOGRAFIA}

AKIMOTO, T; NOBE, T; TANABE, S; KIMURA, K. Floor-supply displacement airconditioning: laboratory experiments. ASHRAE Transactions. v. 05(2), p. 739-751, 1999.

ASHRAE - AMERICAN SOCIETY OF HEATING , REFRIGERATING AND AIRCONDITIONING ENGINEERS, INC. ANSI/ASHRAE Standard 55-1992. Thermal environmental conditions for human occupancy. Atlanta: 1992.

. ASHRAE Handbook of Fundamentals. Atlanta: 1997.

ASHRAE HVAC Applications Handbook. Atlanta: 1999.

. ASHRAE Standard 129-1997. Measuring air change effectiveness. Atlanta:

1997.

BAUMAN, F. S.; ARENS, E. A.; TANABE, S.; ZHANG, H.; BAHARLO, A. Testing and optimizing the performance of a floor-based task conditioning system. Energy and Buildings, Lausanne: Elsevier science, v. 22, p. 173-186, 1995.

D'SA, A. Integrated resource planning (IRP) and power sector reform in developing countries. Energy Policy, Guildford: IPC Science and Technology Press, v. 33, p. 1271-1285, 2005.

ENERGYPLUS. EnergyPlus Manual: Documentation Version 2.1. Outubro, 2007.

ERNEST ORLANDO LAWRENCE BERKELEY NATIONAL LABORATORY. Alternative Air Conditioning Technologies: Under-floor Air Distribution (UFAD). U.S. Department of Energy, Energy Efficiency and Renewable Energy. Washington, D.C. 2004.

FANGER, P. O.; LANGKILDE, G. Inter individual differences in ambient temperature preferred by seated persons. ASHRAE Transactions, v. 81 (2), p. 140-147, 1975.

FOUNTAIN, M. E.; ARENS, E. A. Air movement and thermal comfort. ASHRAE Journal, v. 35 (8), p. 26- 30, 1993.

FUKAO, H.; OGURO, M.; ICHIHARA, M.; TANABE, S. Comparison of underfloor versus overhead air distribution systems in an office building. ASHRAE Transactions, v. 108 (1), 2002. 
GIVONI, B. Passive low energy cooling of buildings. New York : John Wiley, 1994.

Climate considerations in building and urban design. New York : Van Nostrand Reinhold, 1998.

GOSCH, S. R.; LAMBERTS, R. Simulação Térmica e Energética de Edificações. Relatório de Iniciação Científica do Departamento de Engenharia Civil da Universidade Federal de Santa Catarina. UFSC, Florianópolis, 2004.

HANZAWA, H. The Field measurement of the under-floor air-conditioning system controlled based on PMV, In: $6^{\text {th }}$ INTERNATIONAL CONFERENCE ON INDOOR AIR QUALITY AND CLIMATE '93, 1993, Helsinki. Proceedings... Finlândia, 1993. v. 5, p. 479-482.

HOLST, J. N. Using Whole Building Simulation Models And Optimizing Procedures To Optimize Building Envelope Design With Respect To Energy Consumption And Indoor Environment. In: $8^{\text {th }}$ INT.L IBPSA CONFERENCE, 2003, Eindhoven. Proceedings... Netherlands, August 11-14, 2003. Disponível em: <http://simulationresearch.lbl.gov/>. Acesso em: nov. 2004.

LEE, J. H.; KATO, S. Optimization of Hybrid Air-conditioning System with Natural Ventilation by Genetic Algorithm and Computational Fluid Dynamics. In: $9^{\text {th }}$ INTERNATIONAL CONFERENCE ON AIR DISTRIBUTION IN ROOMS ROOMVENT2004. Proceedings... Coimbra : Universidade de Coimbra, 2004.

LEE, A. S.; WESTPHAL, F. S. ; LAMBERTS, R. Verificação da eficiência energética de um edifício de escritórios através de simulação computacional: estudo de caso no departamento de engenharia civil da UFSC. In: VI ENCONTRO LATINO - AMERICANO DE CONFORTO NO AMBIENTE CONSTRUÍDO, III \& ENCONTRO NACIONAL DE CONFORTO NO AMBIENTE CONSTRUÍDO. Anais... São Paulo, 2001.

LEITE, B. C. C. ; TRIBESS, A. Thermal comfort in office buildings with underflloor air supply - Quantitative and qualitative analysis. In: HEALTHY BUILDINGS 2003, Cingapura. Proceedings... Singapore, 2003.

Analysis of the underfloor air distribution system: Thermal comfort and energy consumption. In: 8TH INTERNATIONAL CONFERENCE ON AIR DISTRIBUTION IN ROOMS - ROOMVENT 2002. Proceedings... Copenhagen : Elsevier Science Ltd, p. 245-248, 2002.

; Ornstein, Sheila Walber. Work environment thermal evaluation with underfloor air supply applied to a commercial building in Rio de Janeiro, Brazil. In: 7TH INTRERNATIONAL CONFERENCE ON AIR DISTRIBUTION IN ROOMS - ROOMVENT 2000. Proceedings.... Oxford - UK : Elsevier Science Ltd,. v. II, p. 989-994, 2000. 
Avaliação do conforto térmico em ambientes de trabalho com sistema de ar condicionado com insuflação pelo piso e controles individuais de vazão de ar. In: SEMINÁRIO INTERNACIONAL NUTAU 2000: TECNOLOGIA \& DESENVOLVIMENTO. Anais... São Paulo: Universidade de São Paulo, 2000.

OKUYAMA, C. D. Estudo comparativo de condições de conforto térmico em ambientes de escritório com insuflação de ar frio pelo piso e pelo teto. Relatório Iniciação Científica. Escola Politécnica da USP. PIBIC/CNPq, 2004.

PUSTELNIK, M., TRIBESS. A. Avaliação de ambientes com insuflação de ar frio pelo piso utilizando simulação numérica. In: MERCOFRIO 2002 - CONGRESSO DE AR CONDICIONADO, REFRIGERAÇÃO, AQUECIMENTO E VENTILAÇÃO DO MERCOSUL. Anais... Florianópolis, 2002.

ROCK, B.A.; WOLFE, D.J. A sensitivity study of floor and ceiling plenum energy model parameters. ASHRAE Transactions, v.103 (2), p. 16-30, 1997.

SODEC, F.; CRAIG, R. The underfloor air supply system: the european experience. ASHRAE Transactions, Atlanta, v. 96, p. 690-695, 1990.

WESTPHAL, F. Desenvolvimento de um algoritmo para estimativa do consumo de energia elétrica de edificações não residenciais a partir de dados climáticos simplificados. Dissertação (Mestrado). Universidade Federal de Santa Catarina, Florianópolis, 2002.

YORK, TR: Access Floor - Don't plan your building without it. Journal of the International Facilities Management Association. Novembro, 1992. 